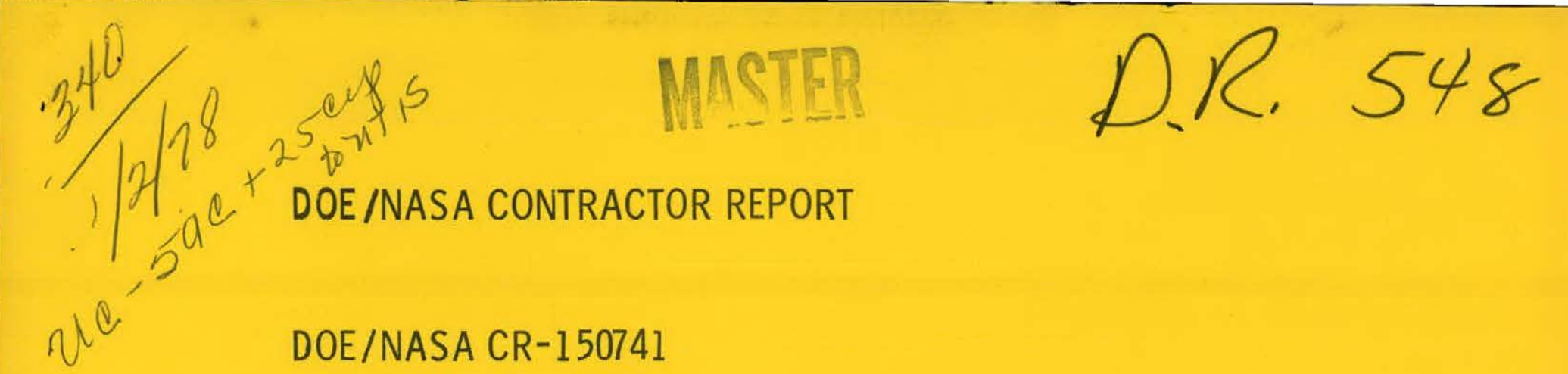

\title{
DESIGN AND INSTALLATION PACKAGE FOR THE SUNMAT FLAT PLATE SOLAR COLLECTOR
}

Prepared from documents furnished by

Calmac Manufacturing Company

150 S. Van Brunt Street

Englewood, New Jersey 07631

Under Contract NAS8-32253 with

National Aeronautics and Space Administration

George C. Marshall Space Flight Center, Alabama 35812

For the U. S. Department of Energy

\section{NOTICE}

PADTIONS OF THIS REPORT ARE ILLEGIBLE. It as been reproduced from the best s. by to permit the broadest possible avail whr ond vy.

\section{U.S. Department of Energy}




\section{DISCLAIMER}

This report was prepared as an account of work sponsored by an agency of the United States Government. Neither the United States Government nor any agency Thereof, nor any of their employees, makes any warranty, express or implied, or assumes any legal liability or responsibility for the accuracy, completeness, or usefulness of any information, apparatus, product, or process disclosed, or represents that its use would not infringe privately owned rights. Reference herein to any specific commercial product, process, or service by trade name, trademark, manufacturer, or otherwise does not necessarily constitute or imply its endorsement, recommendation, or favoring by the United States Government or any agency thereof. The views and opinions of authors expressed herein do not necessarily state or reflect those of the United States Government or any agency thereof. 


\section{DISCLAIMER}

Portions of this document may be illegible in electronic image products. Images are produced from the best available original document. 
NOTICE

Th1s report was prepared to document work sponsored by the Untted States Government. NeIther the United States nor 1ts agents the United States Department of Energy, the United States National Aeronautics and Space Administrat1on, nor any federal employees, nor any of their contractors, subcontractors or the1r employees, make any warranty, express or 1mpl1ed, or assume any legal liability or responsibility for the accuracy, completenss, or usefulness of any information, apparatus, product or process disclosed, or represent that 1ts use would not infringe privately owned rights. 


\begin{tabular}{|c|c|}
\hline $\begin{array}{l}\text { 1. REPORT NO. } \\
\text { DOE/NASA CR-150741 }\end{array}$ & 3. RECIPIENT'S CATALOG NO. \\
\hline \multirow{2}{*}{$\begin{array}{l}\text { 4. TITLE AND SUBTITLE } \\
\text { Design and Installation Package for the Sunmat Flat Plate Solar } \\
\text { Collector }\end{array}$} & $\begin{array}{l}\text { 5. REPORT DATE } \\
\text { March } 1978\end{array}$ \\
\hline & 6. PERFORMING ORGANIZATION CGIDE \\
\hline 7. AUTHOR(S) & 8. PERFORMING ORGANIZATION REPORT \\
\hline \multirow{3}{*}{$\begin{array}{l}\text { 9. PERFORMING ORGANIZATION NAME AND ADDRESS } \\
\text { Calmac Manufacturing Company } \\
150 \mathrm{~S} \text {. Van Brunt Street } \\
\text { Englewood, New Jersey } 07631\end{array}$} & 10. WORK UNIT NO. \\
\hline & $\begin{array}{l}\text { 11. CONTRACT OR GRANT NO. } \\
\text { NAS } 8-32253\end{array}$ \\
\hline & 13. TYPE OF REPOR'I \& PERIOD COVERED \\
\hline \multirow[t]{2}{*}{$\begin{array}{l}\text { 12. SPONSORING AGENCY NAME AND ADORESS } \\
\text { National Aeronautics and Space Administration } \\
\text { Washington, D. C. } 20546\end{array}$} & Contractor Report \\
\hline & 14. SPONSORING AGENCY CODE \\
\hline
\end{tabular}

15. SUPPLEMENTARY NOTES

This work was done under the technical management of Mr. John M. Caudle, George C. Marshall Space Flight Center, Alabama.

16. ABSTRACT

This report contains the information used in evaluating the design of the Sunmat Liquid Flat Plat Plate Solar Collector developed by Calmac Manufacturing Company. Included in this package are the Subsystem Performance Specification, Installation, Operation and Maintenance Manuals, collector sizing guides, and detailed drawings of the single-glazed collector.

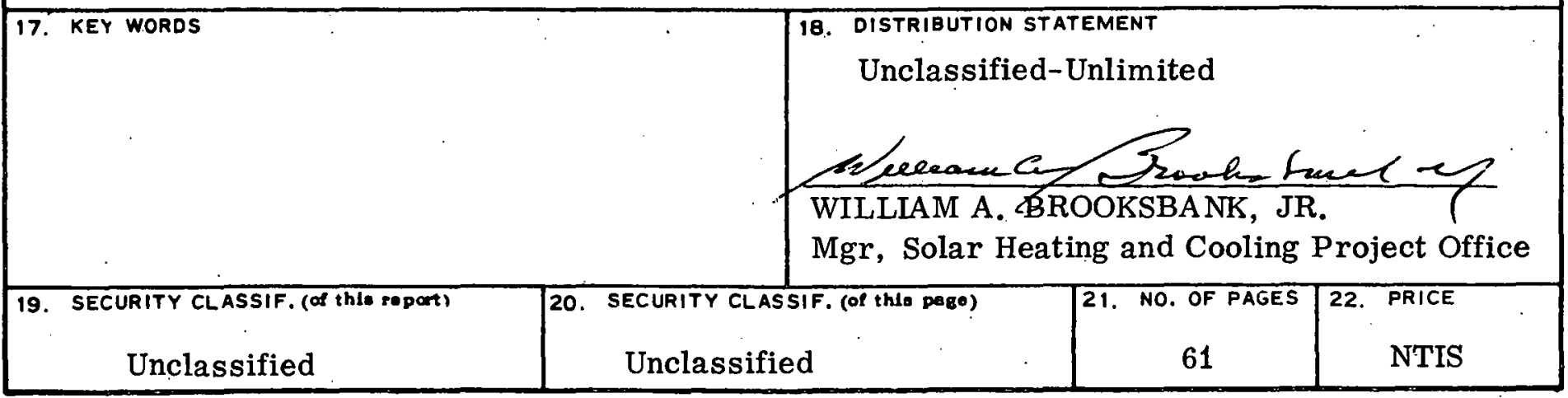




\section{THIS PAGE WAS INTENTIONALLY LEFT BLANK}




\section{ROTICE MN ONLY}

POATIONS OF THIS REPORT ARE ILLEGIBLE. it

has been reproduced from the best available

copy to permit the broadest possible avail.

ability.

\section{TABLE OF CONTENTS}

Subsystem Performance Specification

Installation, Operation and Maintenance Manual

Collector Sizing Guide

Dräwings

Condensation Drier - A-S108A

Top Retainer, Drier - A-S114

Bottom Retainer, Cond. Drier - A-S115

Aluminum Screen, Cond. Drier - A-S113

U-Bend End Assembly, Sunmat - A-S109A

Header, Sunmat

Solder Ring, Sunmat - A-S1ll

Subheader Take of \& U-Bend Tub. - A-S117

Stimpson Clamp Upsetting - A-S1l9

Copper U Bend - A-Slls

Assembly Detail, Coll. Panel - A-S126

Trim Strip, Top \& Bottom - A-S106

Twin Tubing - Cross Section - A-130P-B

Sunmat Solar Coll. Panel - C- S125 - Factory As sembly

Sunmat Solar Collector Assembly - C-155P-B Field Assembly

Sunmat Assembly - C-156 P-B 
SUBSYSTEM PERFORMANCE SPECIFICATION

CALMAC MFG. CORP.

FLATE PLÄTE COLLECTOR

\begin{tabular}{|c|c|c|}
\hline SPECIFICA & ION NO. & SHC -3052 \\
\hline REVISION & 1 & \\
\hline DATE & $2 / 1 / 78$ & \\
\hline & $=$ & \\
\hline REVISION & $=1, \ldots, 2$ & \\
\hline DATE & $3 / 15 / 78$ & \\
\hline
\end{tabular}

$-1-$ 
SUBSYSTEM PERFORMANCE SPECIFICATION

TABLE OF CONTENTS

1: 0 INTRODUCTION

2.0 APPLICABLE DOCUMENTS

Page

3. 0 APPLICATION OF INTERIM PERFORMANCE CRITERIA BY TYPE OF SUBSYSTEM

4.0 DEVIATIONS FROM INTERIM PERFORMANCE CRITERIA

$-4-$

5:0 GOVER NMENT FURNISHED PROPERTY

$-4-$

6. 0 GOVERNMENT DIRECTED REQUIREMENTS

$-4-$

7.0 SUBSYSTEM APPENDICES

$-4-$

8. 0 WARRANTY

$-4-$ 
Specification No.

Revision

SHC -3052

Date $2 / 1 / 78$

SUBSYSTEM PERFORMANCE SPECIFICATION

1.0. INTRODUCTION

This Performance Specification establishes the requirements for the design änd performance of a flat plate collector subsystem for use with solar heating systems. It designates the Interim Performance Criteria applicable to the subsystem and defines the deviations. The appendices specify the performance for each subsystem and the installation drawings.

2. 0 APPLICABLE DOCUMENTS

2. 1 Government Documents

Interim Performance Criteria for Solar Heating and Combined Heating/Cooling Systems and Dwellings, January 1, 1975. U. S. Department of Housing and Urban Development.

2. 2: Contractor Documents

SE-1223 Collector Sizing Guide for Solar Energy Systems, December 1977

SE-1298 SUNMAT Field As sembled Solar Collector Installation, Operation, Service Manual \& Applications Guide, December 1977

SE-3056 SUNMAT Solar Collector Installation, Operation and Service Manual Appliçations Guide, December 1977

2. 3 Other Documents

None 


\section{SUBSYSTEM PERFORMANCE SPECIFICATION}

3.0 APPLICATION OF INTERIM PERFORMANCE CRITERIA BY TYPE OF SUBSYSTEM

The application of each paragraph of the Interim Performance Criteria to each type subsystem is provided in the following table: :

Table I - Residential Subsystems

4. 0 DEVIATIONS FROM INTERIM PERFORMANCE CRITERIA

There are no deviations to the Interim Performance Criteria.

5. 0 GOVERNMENT FURNISHED PROPERTY

None.

6. 0 GOVERNMENT DIRECTED REQUIREMENTS

None.

7. 0 SUBSYSTEM APPENDICES

Appendix A - Technical Performance Requirements

\subsection{WARRANTY}

Contractor warrants for a period of five years that the solar collector materials will be free of defects in quality and workmanship. Warranty is limited to shipping replacement parts prepaid which in the contractor's opinion are required to correct such defects. No field labor is included.

APPENDIX A - Technical Performance Requirements

The solar collector will collect a minimum of 500 BTU of energy per day per square foot of collector surface at an inlet fluid temperature equal to or greater than $130^{\circ} \mathrm{F}$ for the following conditions:
Tilt Angle
Azimuth
Ambient Temp.
- $50^{\circ}$ with Horizontal
- Due South
Wind Velocity
Date
- $40^{\circ} \mathrm{F}$. Average
Noon Solar Flux Normal to
Collector Surface
Longitude
Latitude
- 600 Ft. Per Min。 Average
- November 21
- 290 BTU Per Hour Sq. Ft
- $74^{\circ}$
$-41^{\circ}$ 


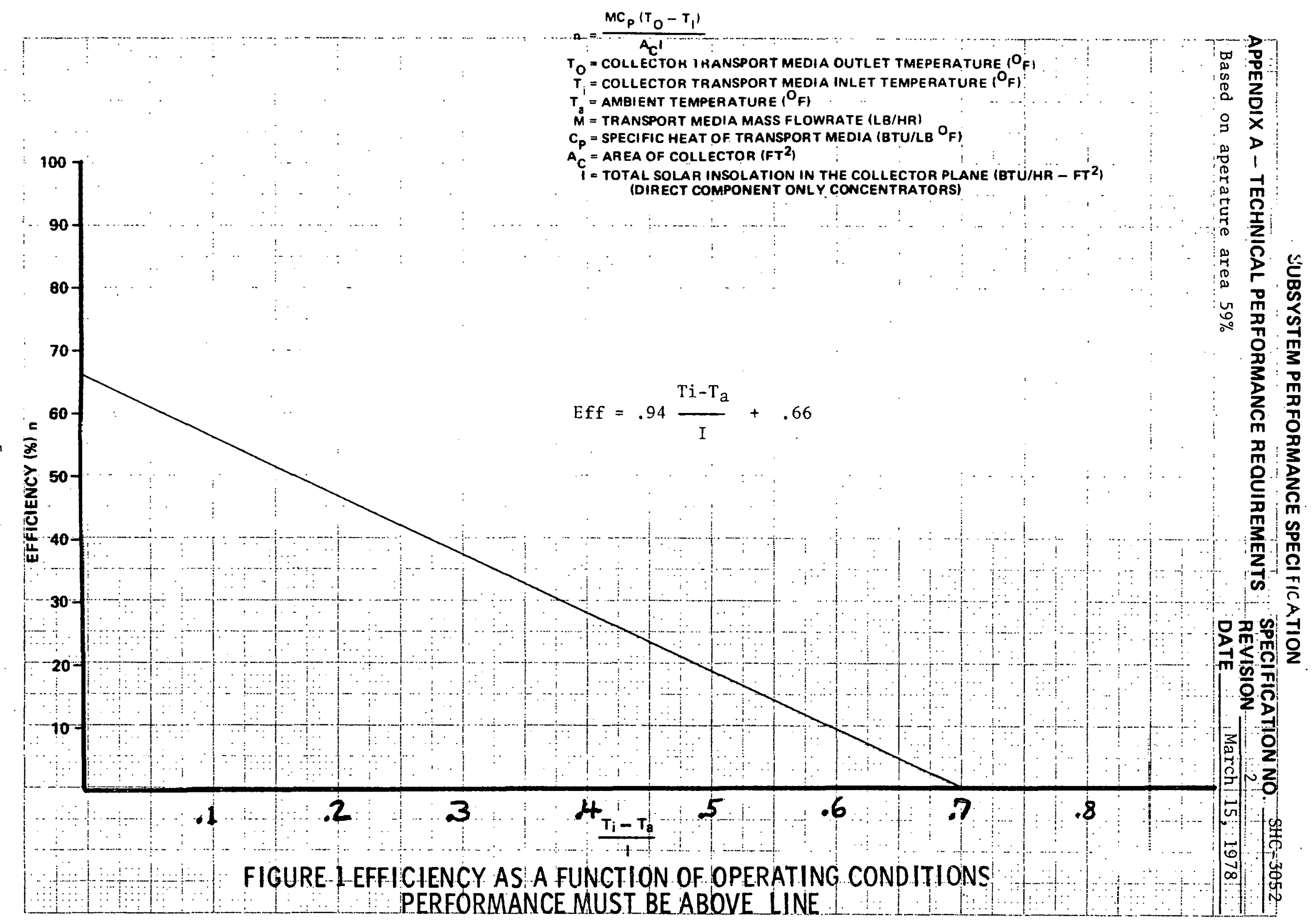


DATE $271 / 78$

RESIOENTIAL SUSSYSTEMS. INTER IM PERFORMANCE CRITERIA SUMMARY

SHEET 1 OF_ 6

SUBSYSTEBA APPLICATION

A- APPLICAgle tO TYPE SYSTEMS INDICATEO

NA- NOT AMPLICABLE
TYPE SYSTEMS

H - HEATING

HC - HEATING ANU CINIIING

HW - HOT.NATEH

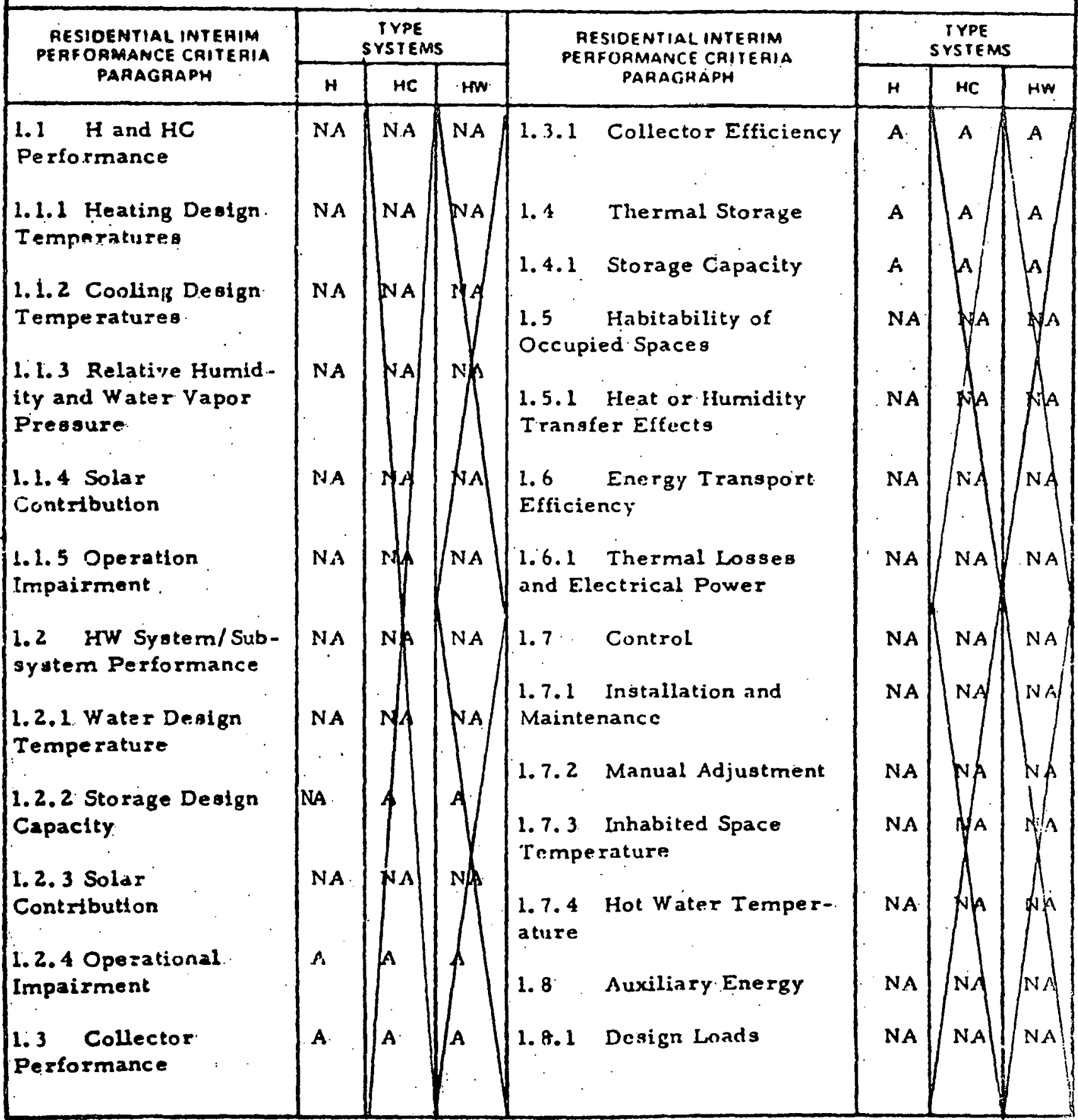


SPECIFICATION NO. SHC-3052

TABLE I

REVISION

1

DATE

$2 / 1 / 78$

RESIDENTIAL SUBSYSTEMS. INTER IM PERFORMIANCE CRITERIA SUMMARY

SUBSYSTEA APPLICATION:

A - APPLICAgLE TO TYPE SYSTEMS INDICATED

NA- NOT AnPLITABLE
TYPE SYSTEMS

H - HEATING

HC - HEATING AND CIIDLING

HW: - HOT WATEA

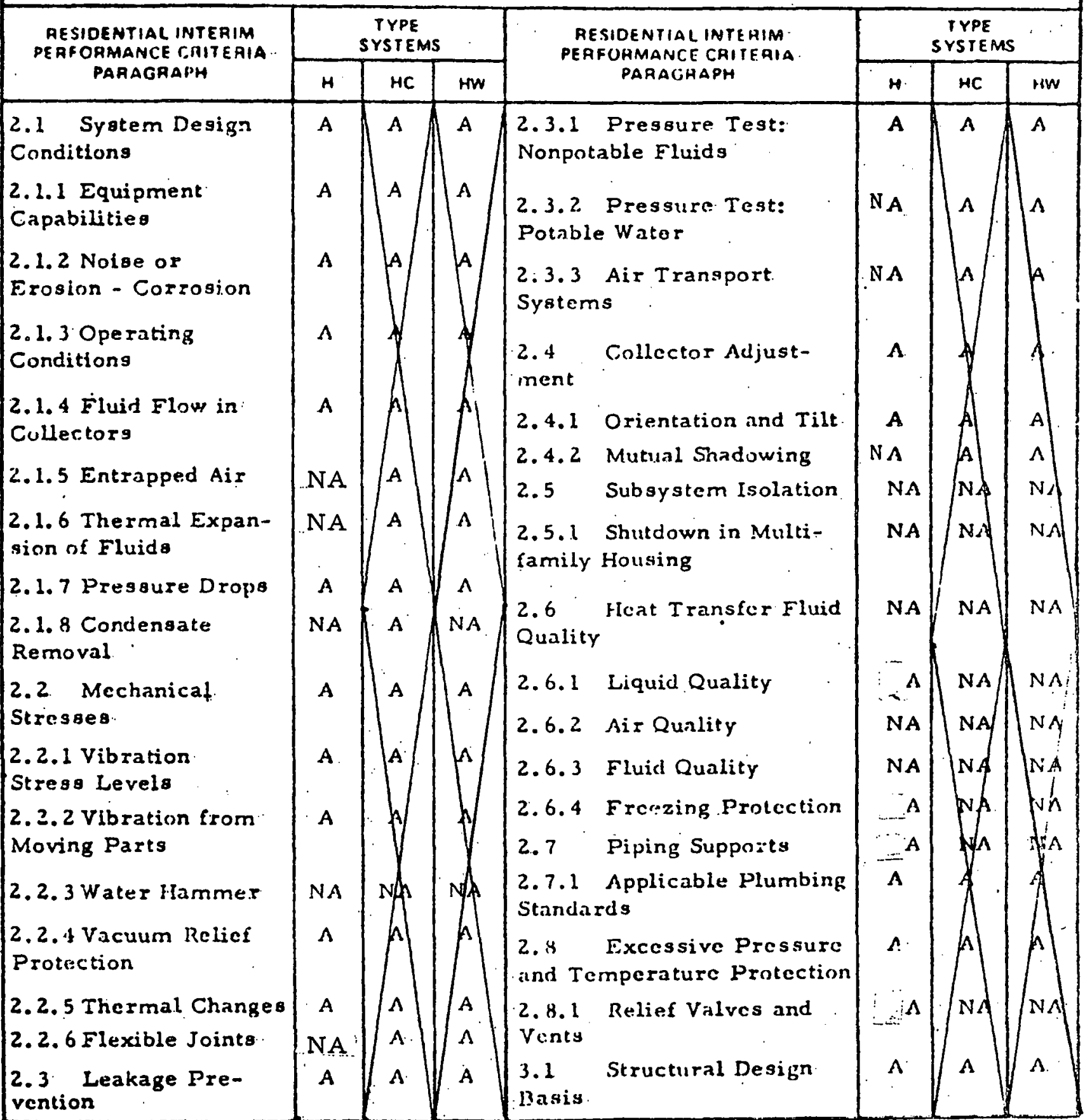


SPECIFICATIONS NO SHC-3052

TABLE I AEVISION

oATE 1

(1)

RESIDENTIAL SUBSYSTEMS. INTER IM PERFORMANICE CRITERIA SUMMARY

SUBSYSTEM APPLICATION

A - APPLICABLE. TO TYPE SYSTEMS INOICATED

NA - NOT AMPLICABLE

SHEET 3 OF 6

IYPE SYSTEMS
H . HEATING
HC .. HEATING ANU CIOILING
HW - HOT WATEH

RESIOENTIAL INTERIM
TEHF ORMANCE CRITERIA PARAGRAPH

3.1.1 Applicable Standards

3.1.2 Service Loads

3.2 Fallure Loads and Load Capacity

3.2.1 Ultimate Load Combinatione

3.2 .2 Ice Loads

3.2.3 Vehicular Loads

3.2.4 Load Capacity

3.3 Damage Control

3.3.1 Resigtance to Damage

3.3.2 Glazing Design

3.4 Cyclic Loado

3.4.1 Deflection

Limitations

3.5 Cutting of:

Structural Elemento

3.5.1 Design Provisions.

3.6 Crcep and Residual Deflection

3.6.1 Deflection

Limitation.

3.7 Hail Resiatance

3.7.1 Hail Size and Loading

3.8 Constraint Load.

\begin{tabular}{|c|c|c|c|c|c|c|}
\hline \multicolumn{3}{|c|}{$\begin{array}{l}\text { TYPE } \\
\text { SYSTEMS }\end{array}$} & \multirow{2}{*}{$\begin{array}{c}\text { AESIOENTIAL INTEIIIM } \\
\text { PERFOIIMANCE CRITEAIA } \\
\text { PAPAGHAPH }\end{array}$} & \multicolumn{3}{|c|}{$\begin{array}{c}\text { IYPE } \\
\text { SYSTEMS }\end{array}$} \\
\hline H. & HC & HW & & H & HC & $11 \mathbf{w}^{\prime}$ \\
\hline A & A & $A$ & $\begin{array}{l}3.8 .1 \text { Foundation } \\
\text { Scttlement }\end{array}$ & $\Lambda$ & $\Lambda$ & $\Lambda$ \\
\hline A & A & $A$ & 3. 9 Ponding Condition & $A$ & $\Lambda$ & $\Lambda$ \\
\hline A & A & $A$ & 3.ソ.1 Design Provisions & NA & $\Lambda$ & $\Lambda$ \\
\hline$A$ & 4 & (1) & $\begin{array}{l}4.1 \quad \text { Plumbing and } \\
\text { Electrical Installation }\end{array}$ & A & A & \\
\hline & & & 4.1.1 Plumbing Codes & A & b & \\
\hline $\mathrm{NA}$. & A & A & $\begin{array}{l}\text { 4.1. } 2 \text { Electrical Codes. } \\
\text { (for sensors) }\end{array}$ & A & & \\
\hline & & & 4.2 Fail-Safe Controls & $A$ & IA & A \\
\hline A & A & $A$ & $\begin{array}{l}4.2 .1 \text { System Failure } \\
\text { Prevention }\end{array}$ & $\Lambda$ & $\Lambda$ & $\Lambda$ \\
\hline A & $A$ & A & $\begin{array}{l}4.2 .2 \text { Automatic Pressure } \\
\text { Relief Valves }\end{array}$ & $\Lambda$ & A & $\Lambda$ \\
\hline $\mathbf{N}_{A}$ & $\Lambda$ & A & 4.3 Firc Safety & $\mathbf{A}$ & A & $\Lambda$ \\
\hline A & $\Lambda$ & A & $\begin{array}{l}\text { 4.3.1 Applicable Fire } \\
\text { Standards }\end{array}$ & $A$ & A & $A$ \\
\hline & & & $\begin{array}{l}4.3 .2 \text { Penetrations thrnugh } \\
\text { Fire Rated } \Lambda \text { semblies }\end{array}$ & $N \Lambda$ & NN & $\mathrm{NA}$ \\
\hline$\sqrt{1} A$ & & & 4.4 Toxic & $\Lambda$ & $A$ & I \\
\hline NA & $N A$ & & $\begin{array}{l}\text { 4.4.1 Provisiong of Catch } \\
\text { Basins }\end{array}$ & A & ay & \\
\hline NA & NA & & $\begin{array}{l}\text { 4.4.2 Detection of Toxic } \\
\text { and Flammable Fluids }\end{array}$ & NA & $y$ & $A$ \\
\hline 20 & & & 4.5 Safety & NA & NA & Nh \\
\hline A & $A$ & $A$ & $\begin{array}{l}\text { 4.5.1 E.mergency Egress } \\
\text { and Access }\end{array}$ & NA & NA & NA \\
\hline$\Lambda$ & A & A & $\begin{array}{l}4.5 .2 \text { Identification and } \\
\text { Location of Controls }\end{array}$ & $\mathbf{A}$ & A & $\Lambda$ \\
\hline
\end{tabular}


STICIFICAIION NOI SHC-3052

TABLE I

RF VISION

1

DATE

-

DATE

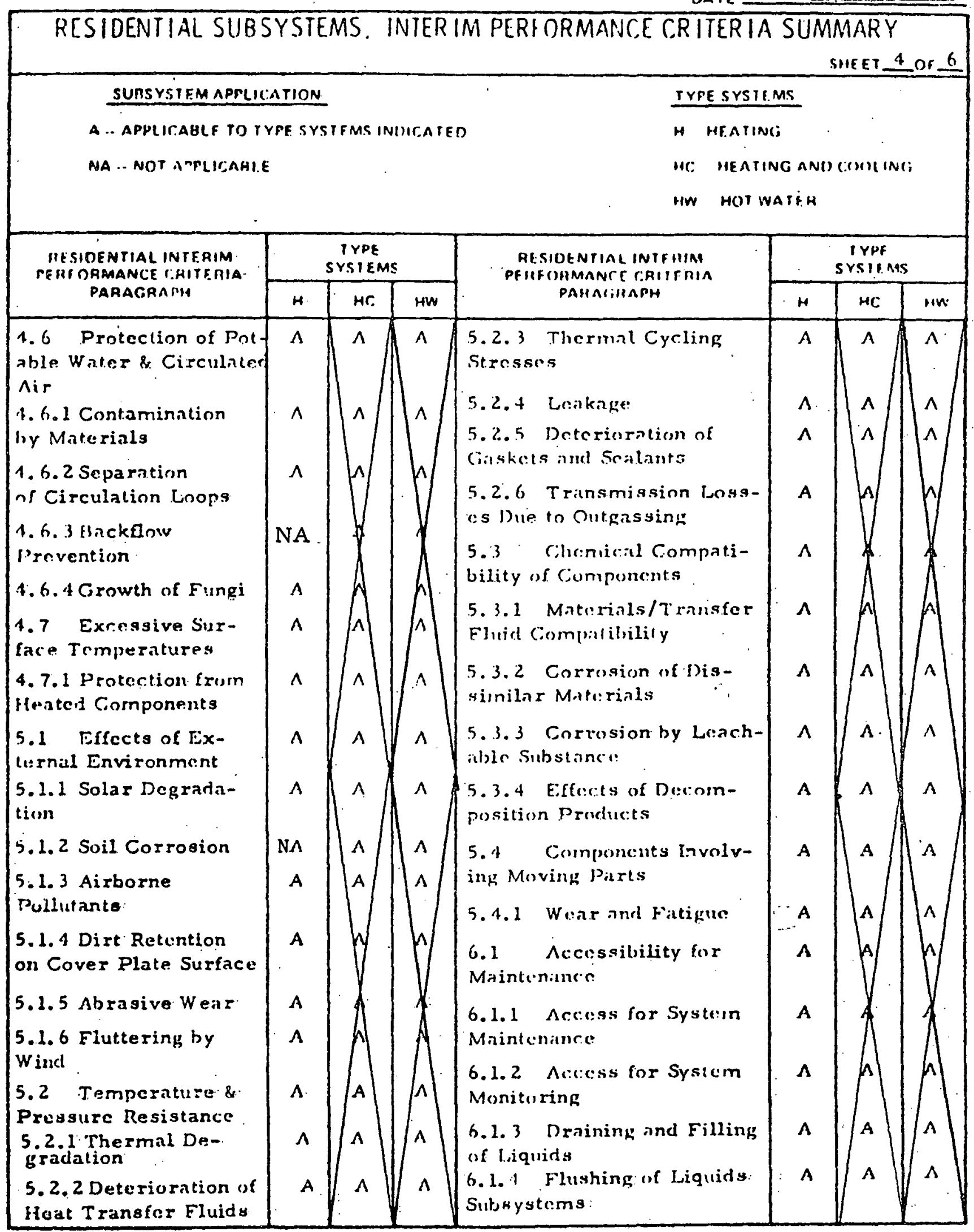


SPECIFICATION NO. SHC- 3052

TABLE I

REVISION

$\frac{1}{2 / 1 / 78}$

RESIOENTIAL SUBSYSTEMS, INTER IM PERFORMANCE CR ITER IA SUMMARY

SHEET 5 OF 6

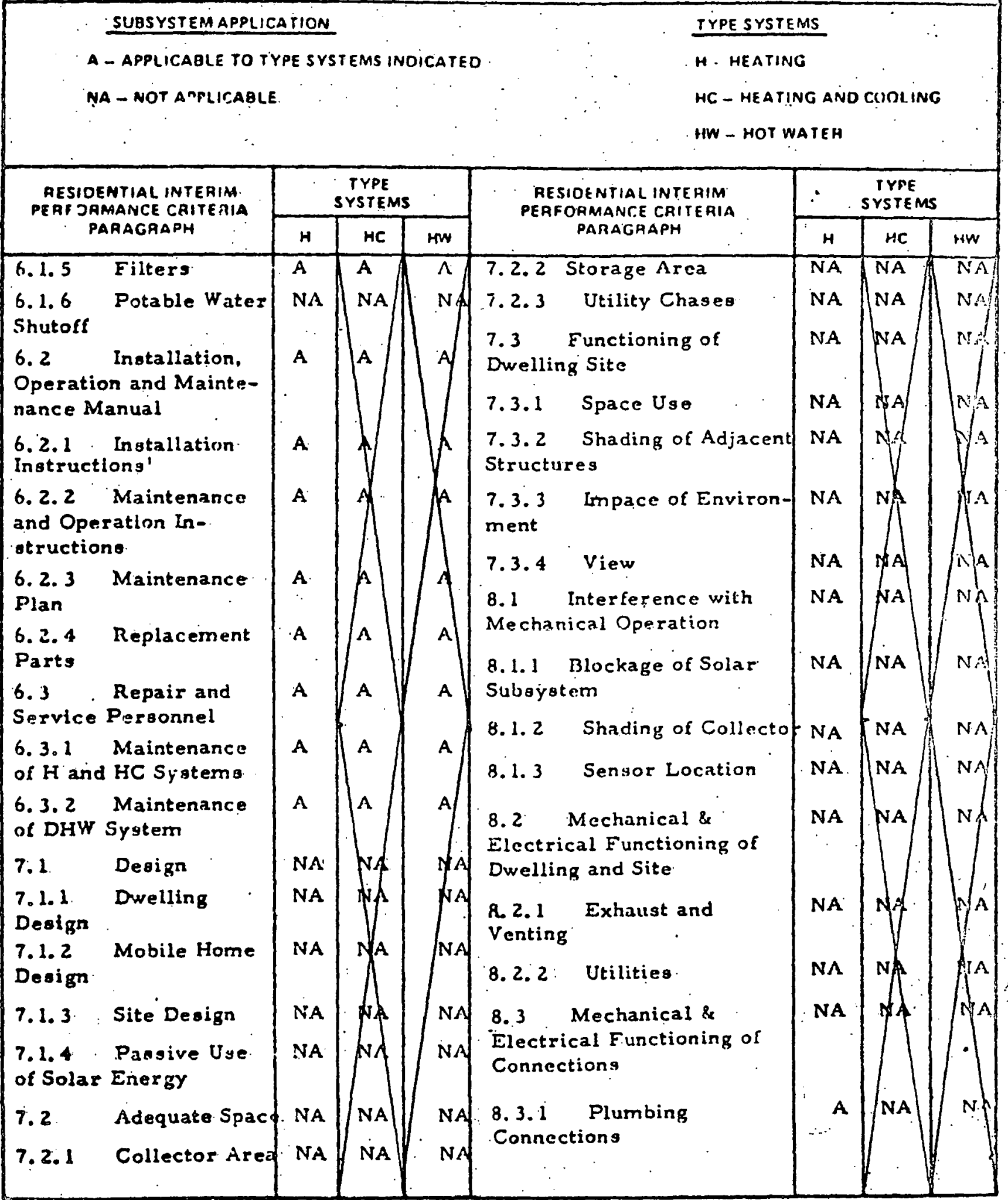


TABLE I

SPECIFICATION NO. SHC-3052

AEVISION $-\frac{1}{2 / 1 / 78}$

DATE- $-2 / 1 / 78$

RESIDENTIAL SUBSYSTEMS, INTER IM PERFORMANCE CR ITER IA SIIMMARY

A - APPI.JIARLE TO TYPE SYSTEMS INDICATED

NA - NOT ANFLITABLE

SHEET 6 _or 6

TYPE SYSTEMS

H. - HEATING

HC... HH.ATING AND CIIDI.ING:

HW - HOT WATEH

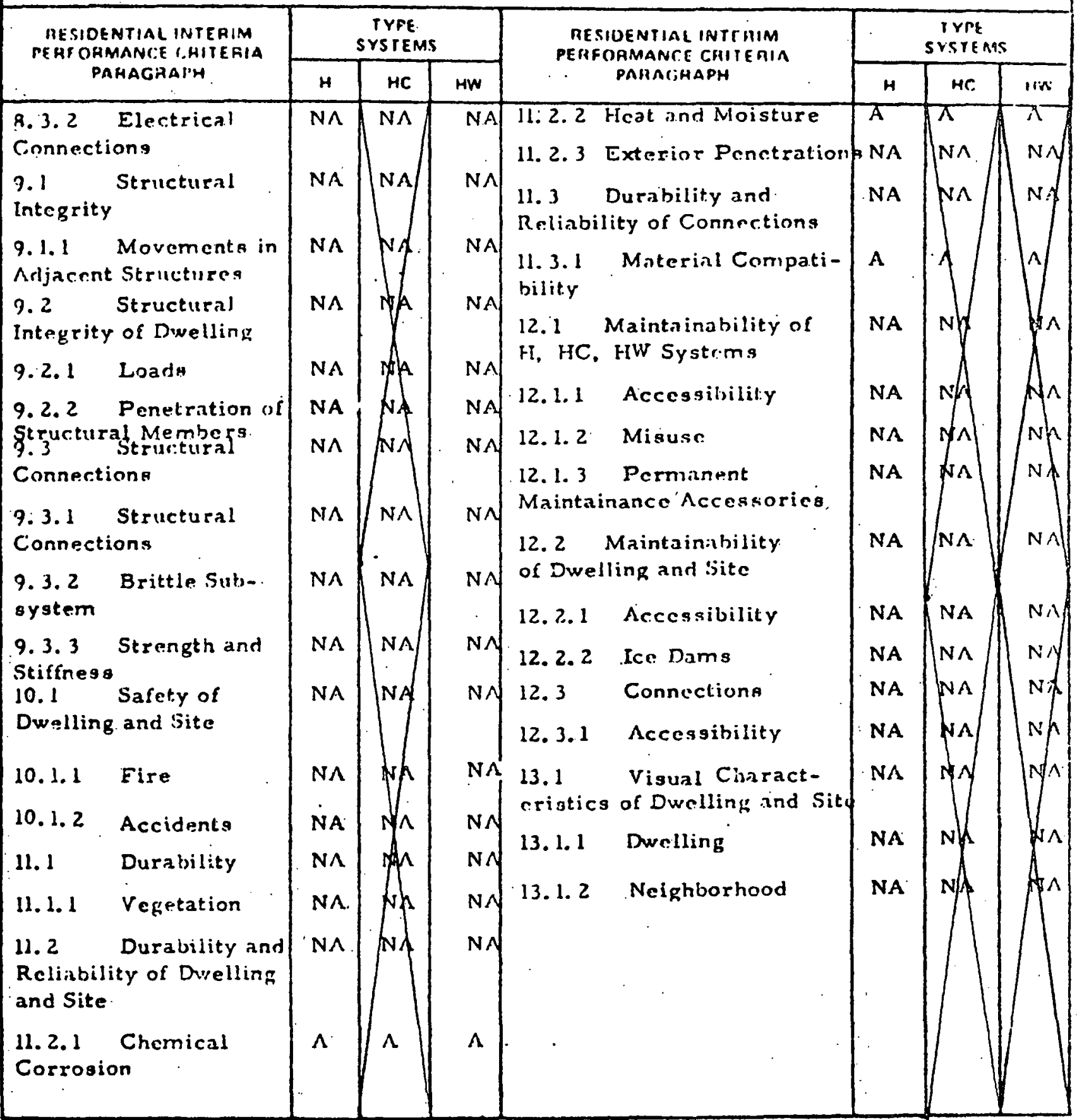


THIS PAGE

\section{WAS INTENTIONALLY LEFT BLANK}


INSTALLATION, OPERATION AND MAINTENANCE MANUAL 


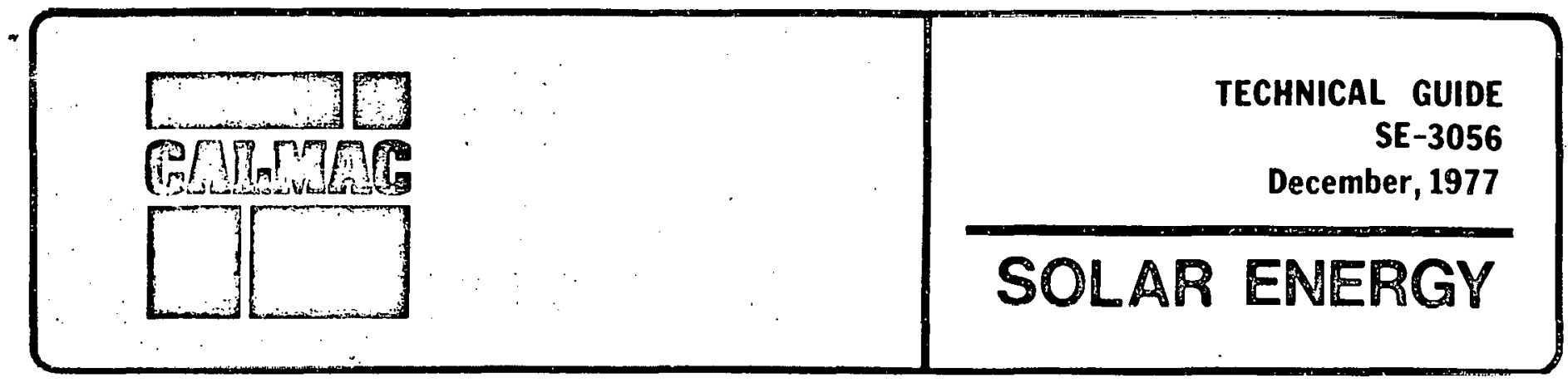

\section{SUNMAT Solar Collector}

\section{Installation, Operation and Service Manual}

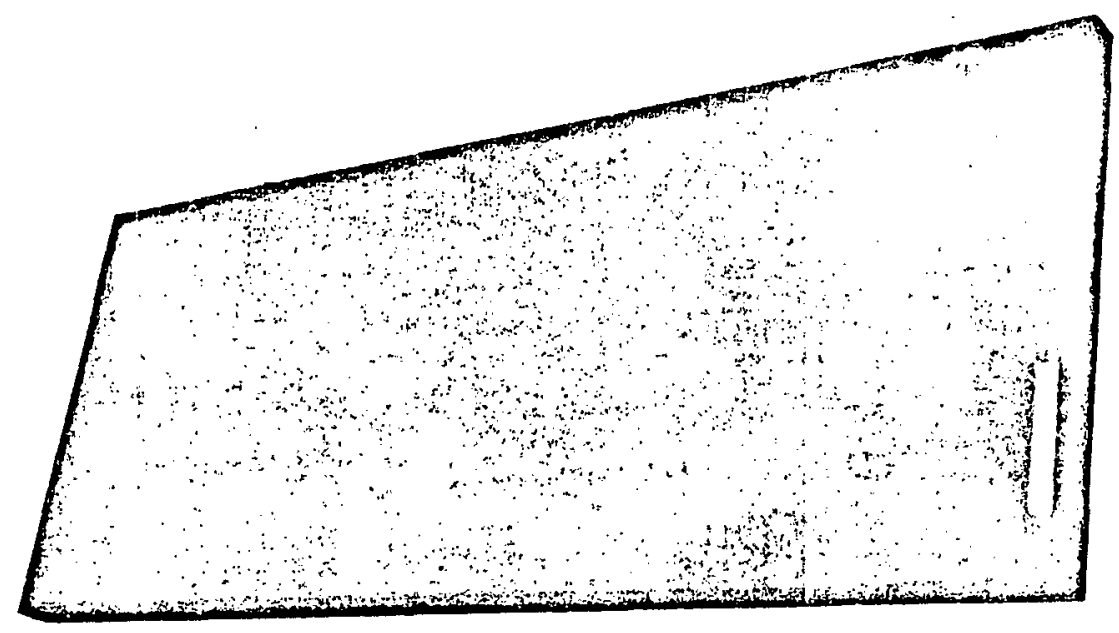

\begin{tabular}{|c|}
\hline INDEX \\
\hline 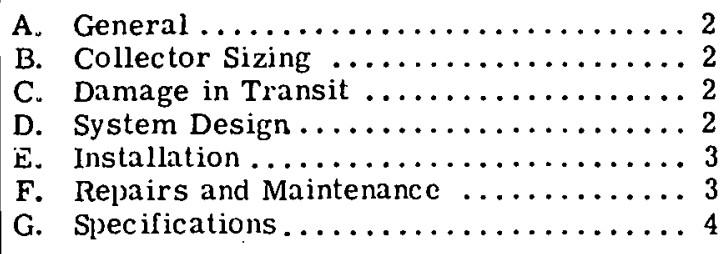 \\
\hline
\end{tabular}

This Technical Guide is written to provide a complete and comprehensive procedure for the installation of the SUNMAT Solar Collector. It is not the intent of this guide to exclude sound and proven methods of installation by contractors who have, through experience and past performance, developed an efficient method of installation expertise.

ALL work must be performed in accordance with LOCAL, STATE and NATIONAL codes. 


\section{A General}

1. The SUNMAT Solar Collectur has been specially designed for space heating and other solar applications requiring large collector areas. The panels are custom-built to fit the dimensions of the roof - - a feature that speeds installation and improves esthetics. The panels can also be built 'in very large sizes--up to $4^{\prime}$ by $2^{\prime}$ '. This means lower costs for plumbing and installation. The extensive use of synthetic materials makes them very. lightweight and reduces corrosion problems. The special zipper lock feature allows easy access to the absorber in the event servicing is necessary.

\section{B. Collector Sizing}

1. The proper sizing of a collector system is a complex process and a number of acceptable methods are available. For a proven, workable procedure refer to CALMAC Technical Guide $\mathrm{SE}-1223$. The efficiency of the collector--a key input in the sizing calculations--is shown in Figure 1-1.

\section{Damage in Transit}

1. Upon receipt of shipment of this material, inspect all cartons for external damage. If external damage is noted, open the carton and inspect for damage to equipment. Mark the number of cartons received in this condition on the delivering carrier's waybill, and request the services of the inspector.

2. If upon opening a carton concealed damage is discovered, open the entire shipment and note all equipment so damaged. Contact the delivering carrier and request inspection of the damaged equipment. Do not destroy the carton as the inspector from the freight company will need this to determine the reason for damages.

\section{EFFICIENCY}

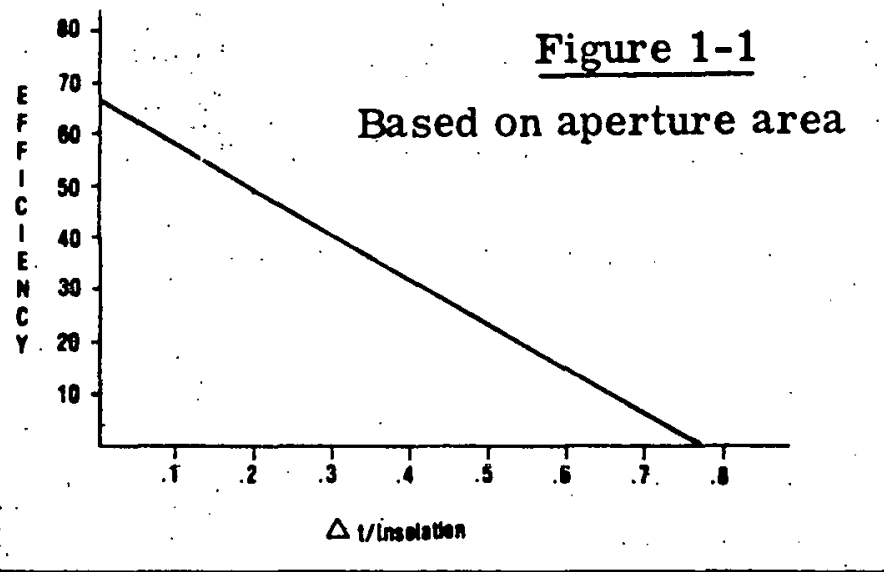

3. Normally, claims for any and all damages should be filed with the freight company within five working. days after receipt of shipment.

4. Since all materials are sold FOB factory, it is the responsibility of the consignee to file claims with the delivering carrier for materials received in damaged condition.

\section{System Design}

1. Air Vent. An air vent should be installed at the highest point in the supply or return line in order to release air trapped in the piping.

2. Expansion Tank. An expansion tank is required in the supply or return line to allow for thermal expansion and contraction of the heat transfer fluid.

3. Pressure Drop. In sizing pumps for systems using water as the heat transfer fluid the pressure drop through the collector can be determined from Figure 1-3. For systems using anti-freeze heat transfer fluids, the pressure drops should be adjusted based on data provided by the supplier of the heat transfer fluid.

4. Relief Valves. A temperature relief valve set to open at $210^{\circ} \mathrm{F}$ and a pressure relief valve set to open at 20 PSI must be included in either the supply or return line. Ordinarily the pressure relief valve is located indoors and connected to a catch basin. The appearance of liquid in the catch basin provides evidence of a malfunction, and in closed loop systems the possible need to add more heat transfer fluid.

5. Strainers. A strainer should be installed in the supply line to the collector. This strainer should be checked one-week after startup and annually thereafter.

6. Pressures and Flows. The maximum recommended operating pressure is 20 PSI. In practice this means that the collector should not be connected directly to a water main. Subjecting the system continuously to pressure above 20 PSI will cause the SUNMAT tubing to stretch over time and may lead to leaks in the system.

The minimum recommended flow rate throughaa collector is 2 GPM to insure optimum efficiency. The maximum recommended flow rate through a collector is 5 GPM. Higher flows will create velocities through the headers which may cause whistling and/or erosion.

7. Gauges. In closed loop systems a pressure gauge reading the system pressure (usually $20 \mathrm{PSI}$ ) is recommended. A drop in system pressure usually indicates a leak in the system. 


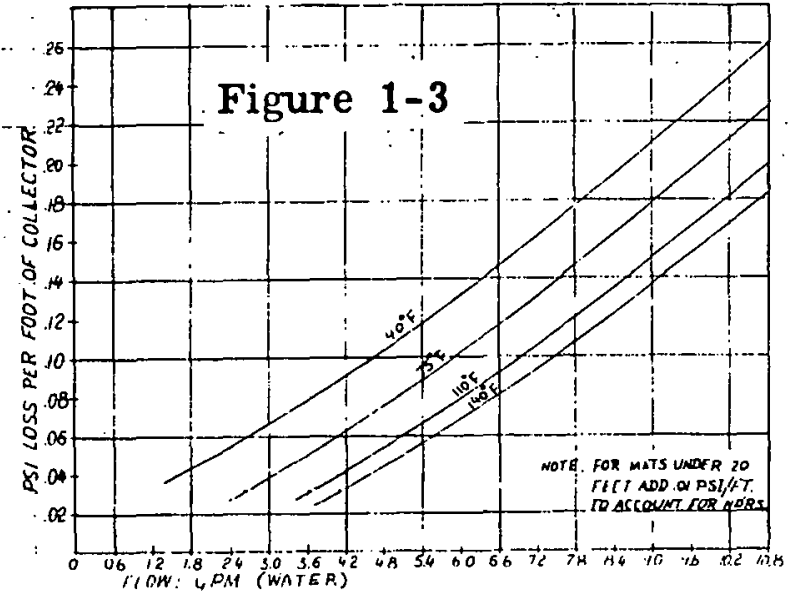

\section{E. Installing the SUNMAT Solar Collector}

1. The infet and outlet plumbing connections to the SUNMAT collector are located at the same end of the collector. The $3 / 4^{\prime \prime}$ NPT connections are located either on the right or left side, both sides, or the back side of the collector. The confiruratiun, which depends on where the pipes will best penetrate the roof, is specified at the time the order is placed with the factory.

2. The collector maly be mounted vertically or horizontally with the plumbing connections at either the top or the bottom. Because the inside diameter of the collector tubing is small, trapped air is readily swept awaly when heat transfer fluid is circulated through the systen, so the headers may be located at the bottom of a vertically mounted collector.
3. When two or more collectors are to be used side-by-side, it is permissible to make the inlet/outlet connections to one collector through one other collector. In this way four collectors can be hooked up to one supply and return line. See Figure 1-2.

4. For esthetic reasons care should be taken to insure that collector sides are parallel to adjacent roof lines. A chalk line is also helpful in getting the correct alignment: It is also helpful to have someone on the ground visually confirm the alignment.

5. If the roof structure underlayment is plywood and is in good condition, the collectors may be bolted to the plywood. The most secure connection is to bolt the collectors into the rafters. Holes in the collector mounting flange should be made to coincide with the location of the rafters. Holes in the flange shculd be $3 / 8^{\prime \prime}$ diameter. To allow for differential expansion they should also generally be elongated (up to 1 " for 25-foot long collectors). To locate the rafters, use a stud finder or tap the roof with a hammer. The more solid sound indicates the rafter. Once the general location of the rafters has been determined, a nail can be driven through the roof to more precisely locate the rafters. These rafter location nails can be driven through a 2" $x 4^{\prime \prime}$ that will also serve as a temporary horizontal support at the bottom of the collectors while they are being bolted to the roof.

6. The collectors can now be brought up onto the roof. One way to bring the collectors onto the roof is to slide them up a ladder. With one person at the top of the ladder pulling and a second person pushing from below, the collector can be moved into place relatively easily.

7. Drill holes through the roof into the rafters. If $1 / 4^{\prime \prime}$ diameter lag bolts are used (min. recommiended diameter) then the holes drilled into the roof should be several drill sizes smaller. After the holes are drilled into the rafter they should be filled with silicone sealant before the bolts are inserted. The bolts should be of sufficient length that they penetrate the plywood underlayment, and engage a rafter by at least $2 "$.

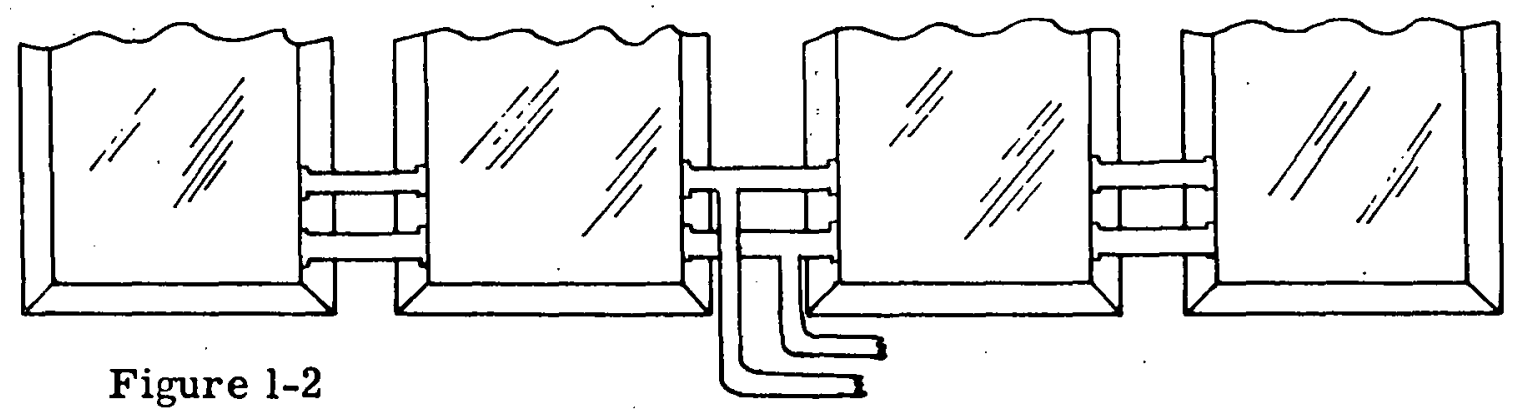


8. The collectors should be spaced a minimum of $1 / 4^{\prime \prime}$ apart so that thermal expansion and contraction of the frame does not disturb the mounting.

9. The manifold inlet and outlet connections are 3/4" NPT. Teflon tape is recommended as a sealant for all threaded connections. Do not insulate the piping or add flashing until the system is pressure-tested. Finding the leaks under flashing and insulation is quite difficult.

10. All roof penetrations should be sealed a second time to insure against leaks. Silicone sealant is a good choice.

11. Remove the nailer at the bottom of the collector that was used to hold the collectors on the roof and fill the nail holes with silicone sealant.

\section{F. REPAIRS AND MAINTENANCE}

1. No routine maintenance is required, but the system should be checked at least annually for breakdowns in the system.

2. Rain should keep the collector cover relatively dirt-free. However, if dirt or dust accumulates, it may be necessary to hose and wash the cover. Normal wind and water gradually ab rade the cover panel, and to insure optimum performance every five to seven years the panel

- must be spray-coated with Kal-Lac, a fast-drying liquid-applied by roller, spray or brush.

3. Any leaks that may develop in the tubing system can be repaired with copper splicer tubes and Stimpson clamps from the repair To make this type of repair a heavy, wide-bladed screwdriver should be used to pop the glazing frame piece off from the side wall. It is usually best to start at one corner. After the plastic zipper lock is undone, the cover can be rolled back to expose the tubing. To repair the tubing the damaged piece should be cut out and a splicer tube put in its place and fastened with Stimpson clamps at either end. Then the glazing should be repositioned in place and the side and top plastic frame pieces snapped back together with a rubber mallet starting at the corners and finishing midway between.

4. Because of the small diameter of the SUNMAT tubing, capillary action prevents complete draining of the tubing. In the event the collector must be completely drained, air pressure must be used to force fluid out of the tubing grid.

5. Every several years flushing the system may be advisable. Water run through the system at 40 PSI is generally adequate. Connections for flushing should be included at the time of installation.

6. Heat Transfer Fluids. Heat transfer fluids should be maintained in accordance with specifications provided by the manufacturer. The SUNMAT system is compatible with glycol anti-freezes. Contact CALMAC before using other anti-freezes.

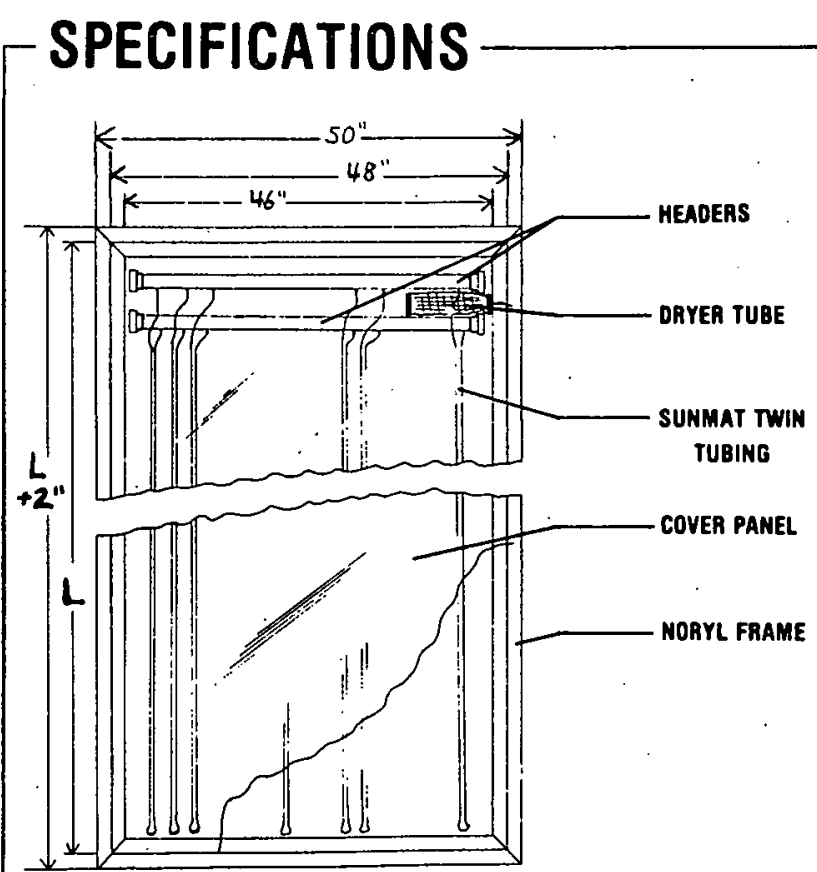

COVER PLATE:

Fiberglass-reinforced polyester, .040"

Transmissivity: $88 \%$ at $0^{\circ}, 78 \%$ at $45^{\circ}$

Wind Load Design: $100 \mathrm{MPH}$

\section{ABSORBER:}

Surface: Black, high temperature urethane coating

Aluminum Sheet: .002" thick

Tubing: 5/16" OD EPDM dual tubing

-Tube spacing $11 / 2$ " on center

- Manlfold and outlet $3 / 4$ " OD type $L$ copper

-U-bends and manifold-to-tubing connections $1 / 4$ " copper INSULATION:

High temperature $\left(350^{\circ} \mathrm{F}\right)$ rigid fiberglass

Density: $4.0 \mathrm{lbs} / \mathrm{ft}^{3}$

2 " on bottom, $R=9 \quad 1$ " on sldes, $R=4.5 @ 70^{\circ} \mathrm{F}$

DESICCANT:

Silica gel in 3/4" $\times 10^{\prime \prime}$ wire mesh tube

COLLECTOR FRAME:

$.125^{\prime \prime}$ thick Noryl extrusion

MOUNTINO PROVISIONS:

1" flange around total perlmeter

External plumbing connections $\$ 4$ " standard plpe thread

FLUID:

Capacity .03 gallons/ft?

MAXIMUM OPERATING TEMPERATURE: $210^{\circ} \mathrm{F}$

MAXIMUM ALLOWABLE TEMPERATUAE: $300^{\circ} \mathrm{F}$

DESIGN LIFE OF COLLECTOR: 20 yearS

FLUID PRESSURES:

Maximum operating pressure: 20 PSI

Tubing test pressure: $80 \mathrm{PSI}$

FLOW RATES:

$.018 \mathrm{GPM}$ / square foot of mat Minimum flow rate: $2.0 \mathrm{GPM}$

NOMINAL PRESSURE DROP:

.16 PSI per foot of length of mat 
THIS PAGE

\section{WAS INTENTIONALLY LEFT BLANK}




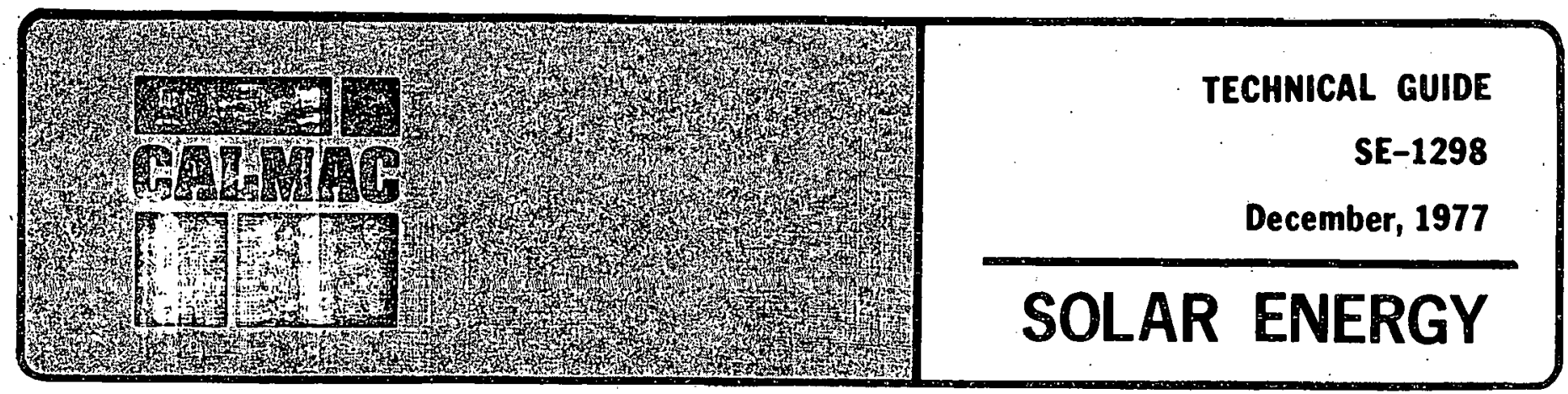

\section{SUNMAT Field-Assembled Solar Collector Installation, Operation \& Service Manual}

\begin{tabular}{|c|}
\hline INDEX \\
\hline 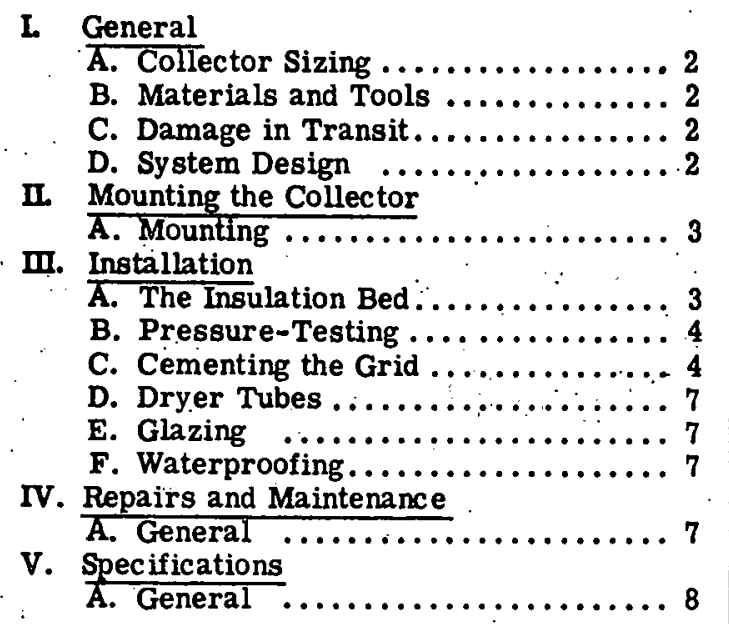 \\
\hline
\end{tabular}

The SUNMAT Field-Assembled Solar Collector System is a non-metallic single-glazed collector designed to be constructed on site in much larger sizes than conventional factory-assembled panels. The system allows the collector to be tailored to fit the dimensions of any installation and provides economies of scale in construction and plumbing.

The SUNMAT consists of a flexible grid of 30 closely spaced elastomer twin tubes cemented to an insulation board base and covered with a flexible reinforced plastic cover. The grid substitutes for the metal absorber plate used in conventional panel-type collectors.

ALL aspects of this installation must comply with NATIONAL, STATE and LOCAL codes.

The information in this manual has been prepared to save time, obtain the best possible installation and insure continuous trouble-free operation of the collector system.

All materials obtained locally or from suppliers other than CALMAC Manufacturing Corporation must be in accordance with specifications set forth in the Section on Specifications. 


\section{GENERAL}

\section{A. Collector Sizing}

The proper sizing of a collector system is a complex process and a number of acceptable methods are available. For a proven, workable procedure refer to CALMAC Technical Guide SE-1223. The efficiency of the collector--a key input in the sizing calculations-is shown in Figure 1.

\section{B. Materials and Tools}

1. The following materials are required to build the collector:

\section{Item}

Absorber tubing system (EPDM tubing grid with copper U-bends and headers)

Absorber cement

Plastic Cover Panel

Insulation Board

Contact Cement

Insulation Cement

F.PDM Hose

Roofing Mastic

Condensation Dryers

Foil-Faced Tape

For further specification on the materials refer to the Specifications Section.

2. The following tools are required to build the collector:

$12 "$ adjustable wrench
12 " pipe wrench
knife
pair of hand gloves
bicycle pump or other source of
compressed air
pair of pliers
measuring tape
straight edge
masking tape

\section{EFFICIENCY}

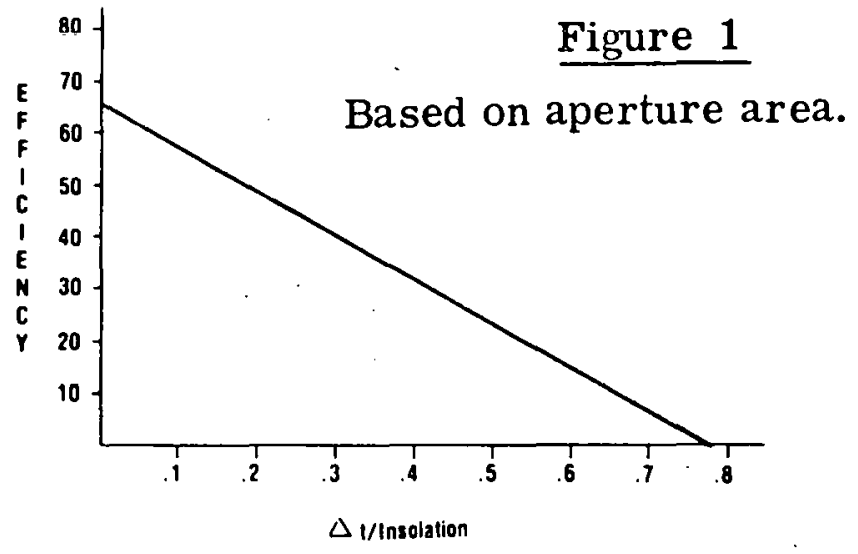

\section{Damage in Transit}

1. Upon receipt of shipment of this material, inspect all cartons for external damage. If external damage is noted, open the carton and inspect for damage to equipment. Mark the number of cartons received in this condition on the delivering carrier's waybill, and request the services of the inspector.

2. If upon opening a carton concealed damage is discovered, open the entire shipment and note all equipment so damaged. Contact the delivering carrier and request inspection of the damaged equipment. Do not destroy the carton as the inspector from the freight company will need this to determine the reason for damages.

3. Normally, claims for any and all damages should be filed with the freight company within five working days after receipt of shipment.

4. Since all materials are sold FOB factory, it is the responsibility of the consignee to file claims with the delivering carrier for materials received in damaged condition.

\section{System Design}

1. Headering. When two or more collectors are to be used and assembled side by side, it is permissible to connect the header system of one collector to the in and oul piping through one other header system. Using a T-connection it is pessible to hook four header systems to the same in and out piping. See Figure 2. 


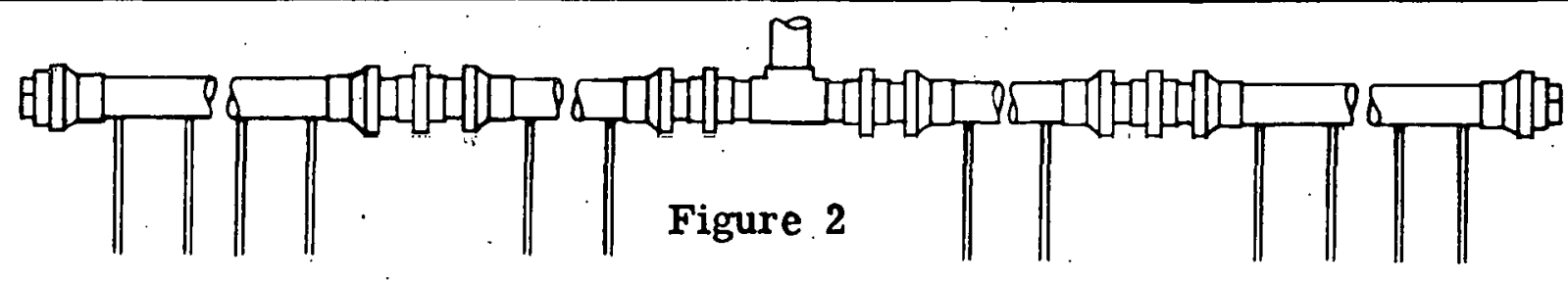

2. Air Vent. An air vént should be installed at the highest point in the supply or return line in order to release air trapped in the piping.

3. Expansion Tank. An expansion tank is required in the supply or return line to allow for thermal expansion and contraction of the heat transfer fluid.

3. Pressure Drop. In sizing pumps for systems using water as the heat transfer fluid the pressure drop through the collector can be determined from Figure 3. For systems using anti-freeze heat transfer fluids, the pressure drops should be adjusted based on data provided by the supplier of the heat transfer fluid.

4. Relief Valves. A temperature relief valve set to open at $210^{\circ} \mathrm{F}$ and a pressure relief valve set to open at 20 PSI must be included in either the supply or return line. Ordinarily the pressure relief valve is located indoors and connected to a catch basin. The appearance of liquid in the catch basin provides evidence of a malfunction, and in closed loop systems the possible need to add more heat transfer fluid.

5. Strainers. A strainer should be installed in the supply line to the collector. This strainer should be checked one week after startup and annually thereafter.

6. Pressures and Flows. The maximum recommended operating pressure is 20 PSI. In practice this means that the collector should not be connected directly to a water main. Subjecting the system continuously to pressure above 20 PSI will cause the SUNMAT tubing to stretch over time and may lead to leaks in the system.

The minimum recommended flow rate throughaa collector is $2 \mathrm{GPM}$ to insure optimum efficiency. The maximum recommended flow rate through a collector is 5 GPM. Higher flows will create velocities through the headers which may cause whistling and/or erosion.

7. Gauges. In closed loop systems a pressure gauge reading the system pressure (usually $20 \mathrm{PSI}$ ) is recommended. A drop in system pressure usually indicates a leak in the system.

\section{MOUNTING THE COLLECTOR}

\section{A. Mounting the Collector}

1. When the system is built on a steeply slanting roof, a scaffolding should always be used. A scaffolding makes the installation much easier and is the safest method.

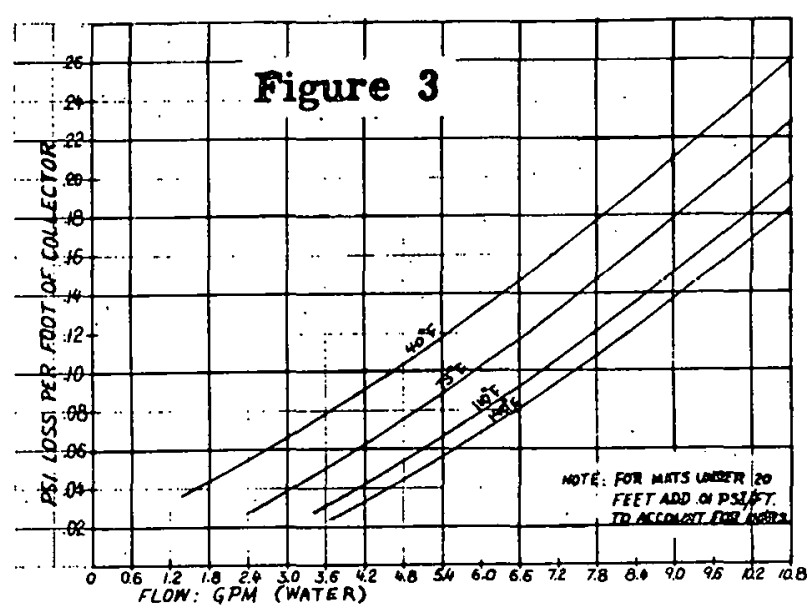

2. The surface on which the SUNMAT system is to be built must be sturdy and flat. As a rule, any normal roofing surface is acceptable as long as the fiberglass insulation which forms the collector bed can be bonded firmly to it with roofing mastic. Sirke the SUNMAT is quite lightweight, installation on an existing roof does not add appreciably to the load on the roof and is usually quite safe.

3. The layout of the collector installation must take into consideration the size and shape of the space available for the collectors. Each grid of the SUNMAT system is 4 ' wide. The length of the SUNMAT collector can be any size up to $50^{\prime}$ and is therefore cut to fit the available space. In laying out the length, however, it is important to keep in mind that an additional 4" must be allowed beyond the desired length of the absorber system for connecting the headers and U-bends. It is also advisable to keep the length of the SUNMAT as long as practicable since this reduces the cost per square foot.

4. The collectors should not be mounted absolutely horizontal since in this position water will pond on the glazing and dirt will accumulate. The minimum recommended slope is 1 in 12 .

\section{INSTALLATION}

\section{A. Constructing the Insulation Bed}

1. Cut and build the bed of insulation board. This bed is made of $1 "$ thick foil-faced fiberglass insulation boards cemented face to face. The bottom boards are $2^{\prime} \times 4^{\prime}$. The top boards are $4^{\prime}$ $x 10^{\prime}$ boards that have been factory-outgassed at $350^{\circ} \mathrm{F}$ for an hour. l" must be trimmed off these boards to allow for the perimeter walls. 


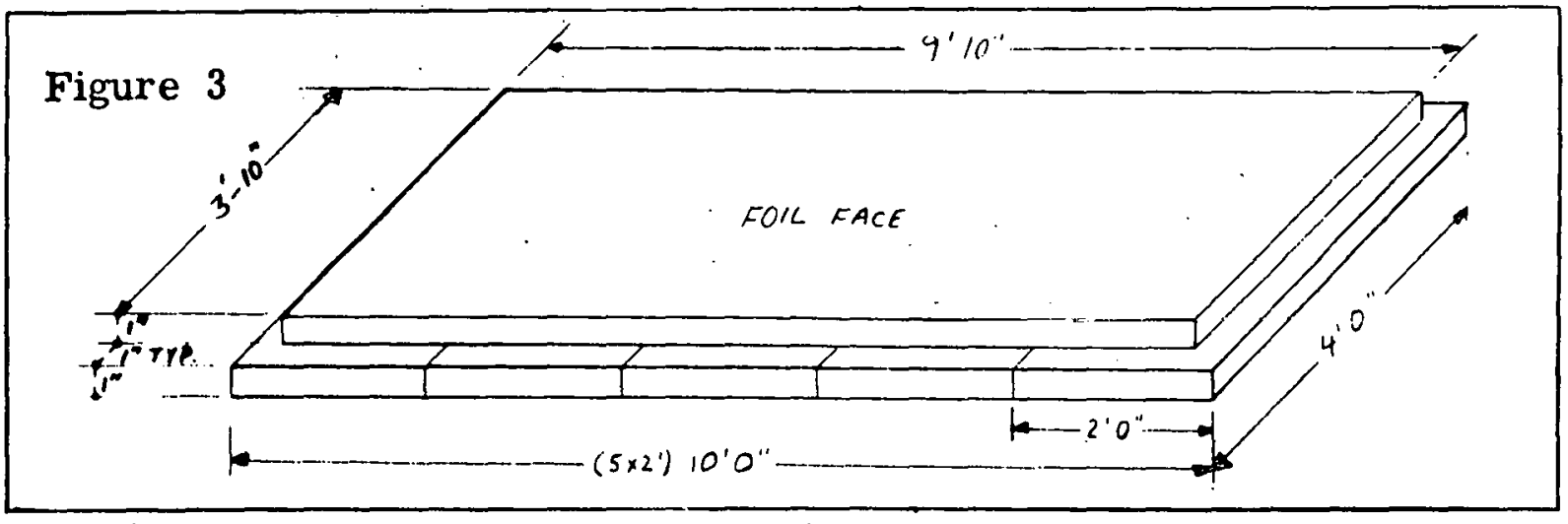

The boards must also be trimmed to the proper length, which is a function of the size of the collector. The top board must be 2 " shorter than the bottom board--again, to allow for the perimeter walls. The unfaced sides of the boards are cemented together using the instiation cenent to makc a 2 " board foil-faced on both sides. In order to make one unified section the top and botton boards are overlapped. The top boards are centered on the bottom board to allow for the perimeter walls. See Figure 3.

2. Cut and cement the fibergliass insulation perimeter strips to the bed. This wall provides the surface to which the cover panel is cemented. The strips are $21 / 2 "$ : wille. The length depends on the size of the collector. Contact cement is used to adhere the strips to the insulation bed. See Figure 4.

3. Mount the insulation board bed on its supporting surface. The bed e:an be affixed directly to smooth supporting surfices with ordinary roofing mastic. On surfices that are irregular, such as shingled roofs, laying down a plywood frame and adhering the bed to the frame with roofing mastic is recommended.

\section{B. Pressure-Testing the SUNMAT for Leatks}

1. Pressure-test the tubing system for leaks using a portable air compressor, bicycle pump or canister of compressed $a \mathrm{ir}$ to pressurize the tubing to $40 \mathrm{PSL}$. One of the headers is supplied with a tank valve to facilitate testing for leaks.

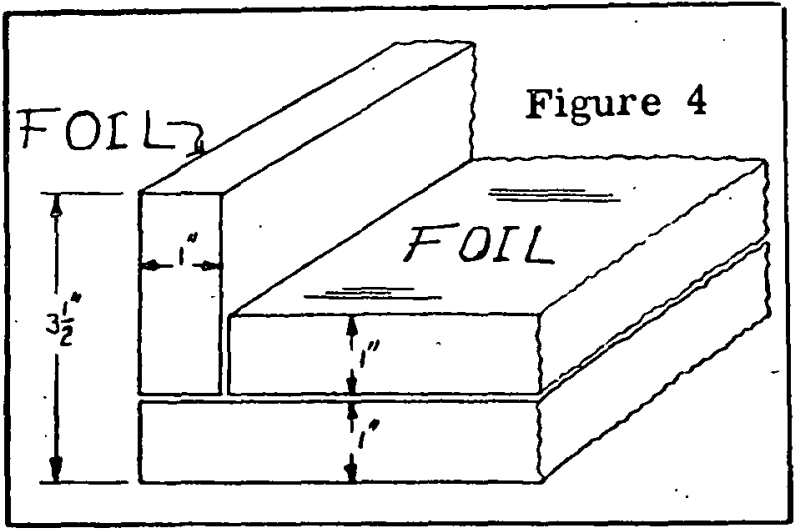

Any leaks should make a hissing sound. Leaks are rare and are usually caused by improper connctions between the SUNMAT tubing and the $\mathrm{U}$-l,ends or headers. Leaks can be detected by applying soapy water and looking for bubbles. Leaks can be repaired by adjusting or replacing the Stimpson clamps. The tubing itself does not renerally leak unless it has been damaged in shipment or handling. Leaks in the tubi gy are repatired with splicers from the repair kit in accordance with instructions in the section on Repairs and Maintenance.

\section{Cementing the SUNMAT Grid to the Insuiation Berl}

1. Position the SUNMIAT rrid in place. The header end of the mat should be butted against the end border of the bed. If the mat is fairly short, it can be placed directly on the insulation. If it is long, it may be easier to roll it off the shippingr roll and onto the insulation bed. The he:lder and $U$-bend ends of the mat should be secured in place with a piece of foil-faced tape messed down between each tube onto the foilfaced insulation bourd, Similarly, foil-faced lape should be used to hold the mat itself in place every four feet. See Figure 5 .

2. Put three słacer blocks in place $12^{\prime \prime}$ apart every two feet. These blocks are made of $11 / 2$ " leniths of $l^{\prime \prime}$ EPDM hose. They are set in place between slightly spread tubes and held in place by the absorber cenient (next step). See Figure 6 .

3. Spray or brush the two-part absorber cement over the entire surface until the aluminum foil is completely blacked out. To insure a good bond the joint where the tubes and foil meet must be filled with adhesive. In mixing the two-part cement, directions on the can should be followed carefully.

4. At the side of the collector where the external plumbing connections are to be made, passageways for the connections should be cut through the perimeter strips and pipe nipples for the connections should be cut through the perimeter strips and pipe nipples extending through the perimeter wall should be installed. At this point in the construction process it is usually advantageous to hook up the sensor that measures the outlet temperature for the differential thermostat and any other valves or vents indicated. See Figure 7. 


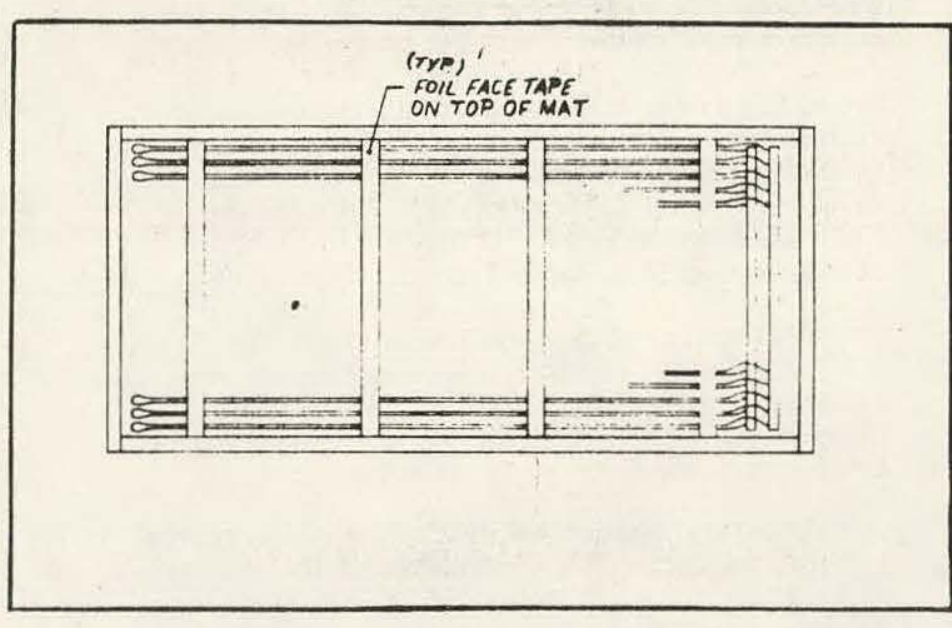

Figure 5

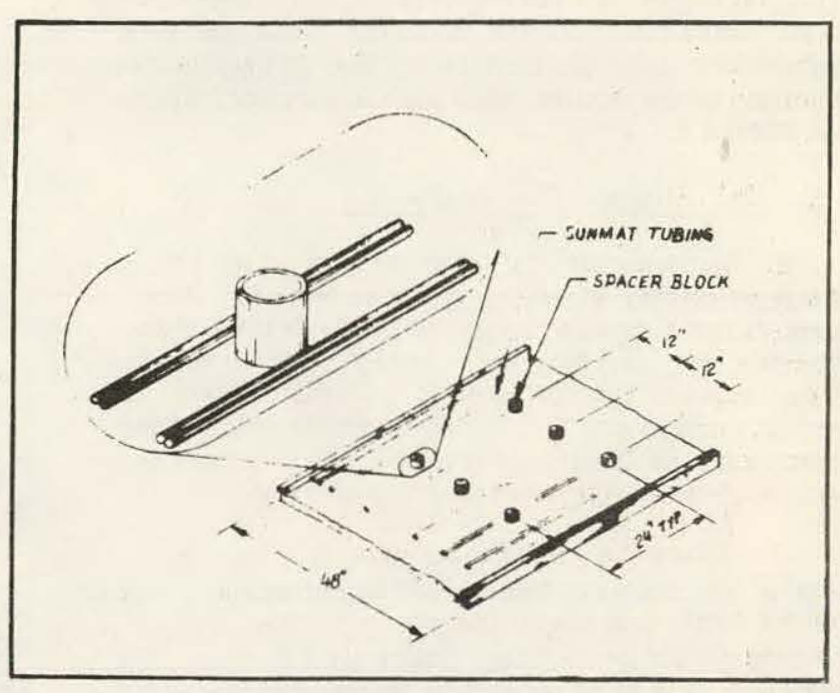

Figure 6

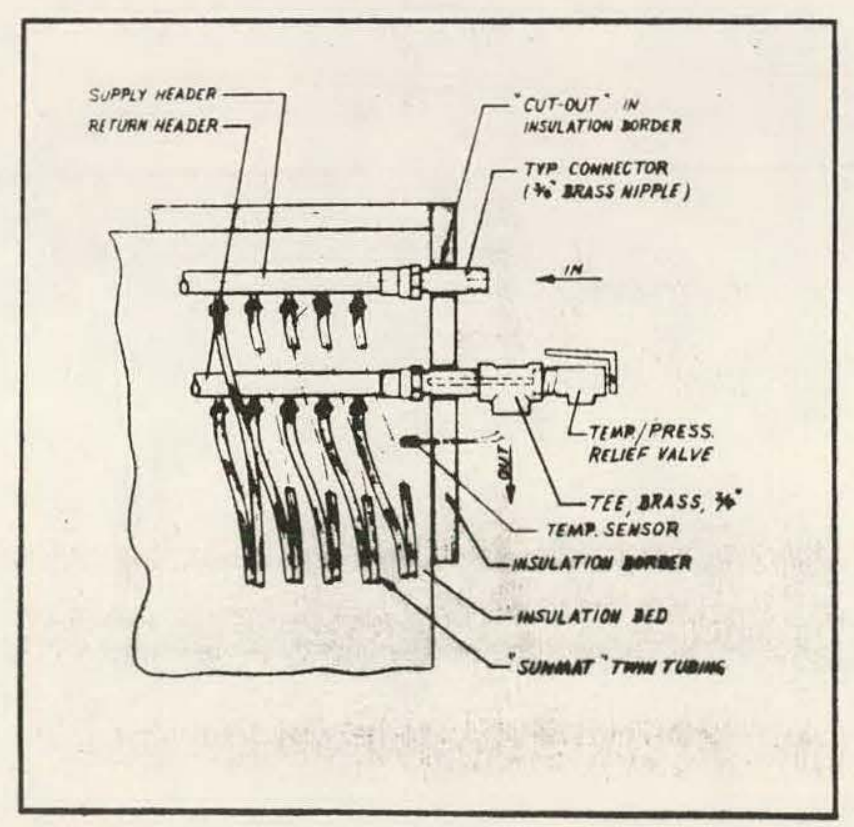

Figure 7

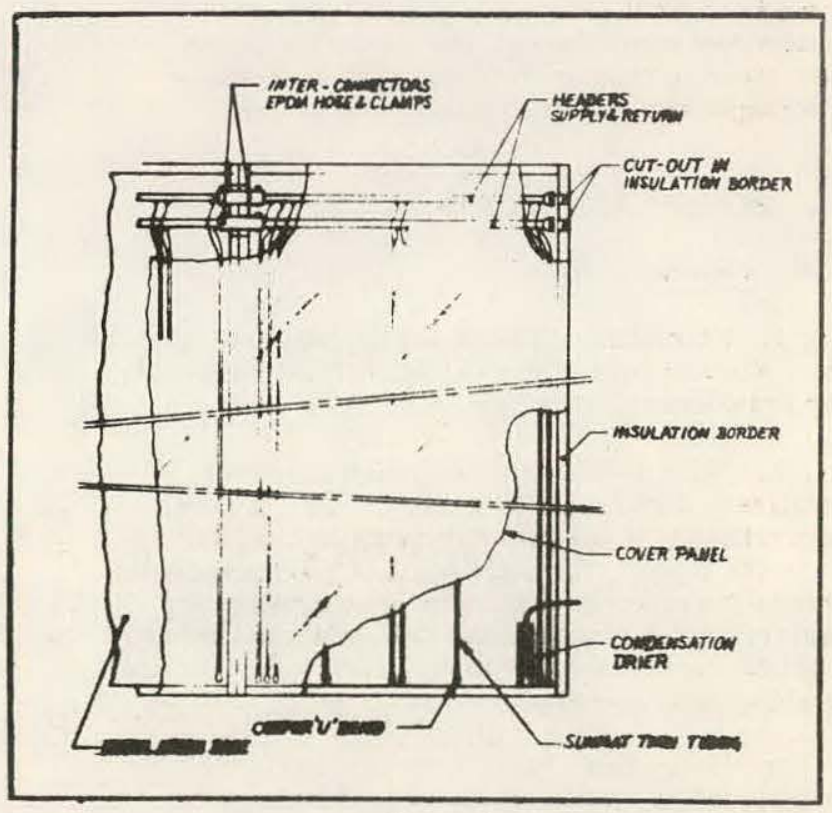

Figure 8 


\section{Dryer Tubes}

1. Install one dryer tube for every 200 square feet of collector or fraction thereof. Dryer tubes are used to prevent the build-up of maisture condensation under the collector glazing. The dryer tube is installed along the outside perimeter by punching an outlet in the border strip with a screwdriver. See Figure 8.

\section{E. Installing the Plastic Glazing}

1. Apply a coat of contact cement to the top edge of the perimeter strip. Start from one end, then move to the sides and down the borders toward the opposite end, catching the spacer blocks as well. If the length of the collector is less than 12 feet, the contact cement can be applied in one step but if the length exceeds 12 feet, more than one step may be necessary since the cement dries quickly.

2. Place the end of the rolled up plastic glazing over the end of the collector coated first, and unroll the glazing. The glazing should be unrolled gradually, making sure that it is running square to the border. After it is completely unrolled, press it lightly against the border and spacer blocks to insure good bonding.

\section{F. Waterproofing the Complete Collector}

1. Waterproof the entire system by applying roofing mastic to all the exposed insulation, and to the 1 " edge of the plastic glazing that overlaps the insulation board perimeter. Cement should be used liberally to make a $\mathbf{s} \in a l$ around the header pipes and dryer tube where they come through the insulation board. Use masking tape on the glazing so as to make a straight edge between mastic and glazing.

\section{REPAIRS AND MAINTENANCE}

\section{A. General}

1. No routine maintenance is required, but the collector should be checked at least annually for breakdowns in the system.

2. Rain should keep the collector cover relatively dirt-free. However, if dirt or dust accumulates, it may be necessary to hose and wash the cover. Normal wind and water gradually abrade the cover panel, and to insure optimum performance every five to seven years the panel must be spray-coated with Kal-Lac, a fast-drying liquid applied by roller, spray or brush.

3. Over time cracks may develop in the waterproofing, particularly in areas where the roofing mastic was put on too thin. These cracks can be easily repaired with fresh mastic.
4. Any leaks that may develop in the tubing system can be repaired with c spper splicer tubes and Stimpson clamps from the repair kit. To make this type of repair a knife should be used to cut through the fiberglass border strips. After the cut is made, the cover can be lifted to expose the tubing. To repair the tubing the damaged piece should be cut out and a splicer tube put in its place and fastened with Stimpson clamps at either end. See Figure 11. Contact cement can then be used to cement the fiberglass back together. Finally a new coat of mastic should be applied to seal the collector.

5. Because of the small diameter of the SUNMAT tubing, capillary action prevents easy draining of the tubing. In the event the collector must be completely drained, air pressure must be used to force fluid out of the tubing grid.

6. Every several years flushing of the system may be advisable. Water run through the system at 40 PSI is generally adequate. Connections for flushing should be included at the time of installation.

7. Heat Transfer Fluids. Heat transfer fluids should be maintained in accordance with specifications provided by the manufacturer. The SUNMAT system is compatible with glycol anti-freezes. Contact CALMAC before using other anti-freezes.

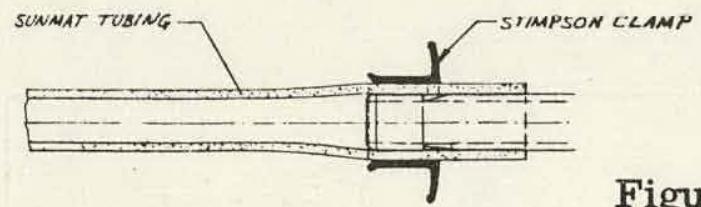

Figure 11 

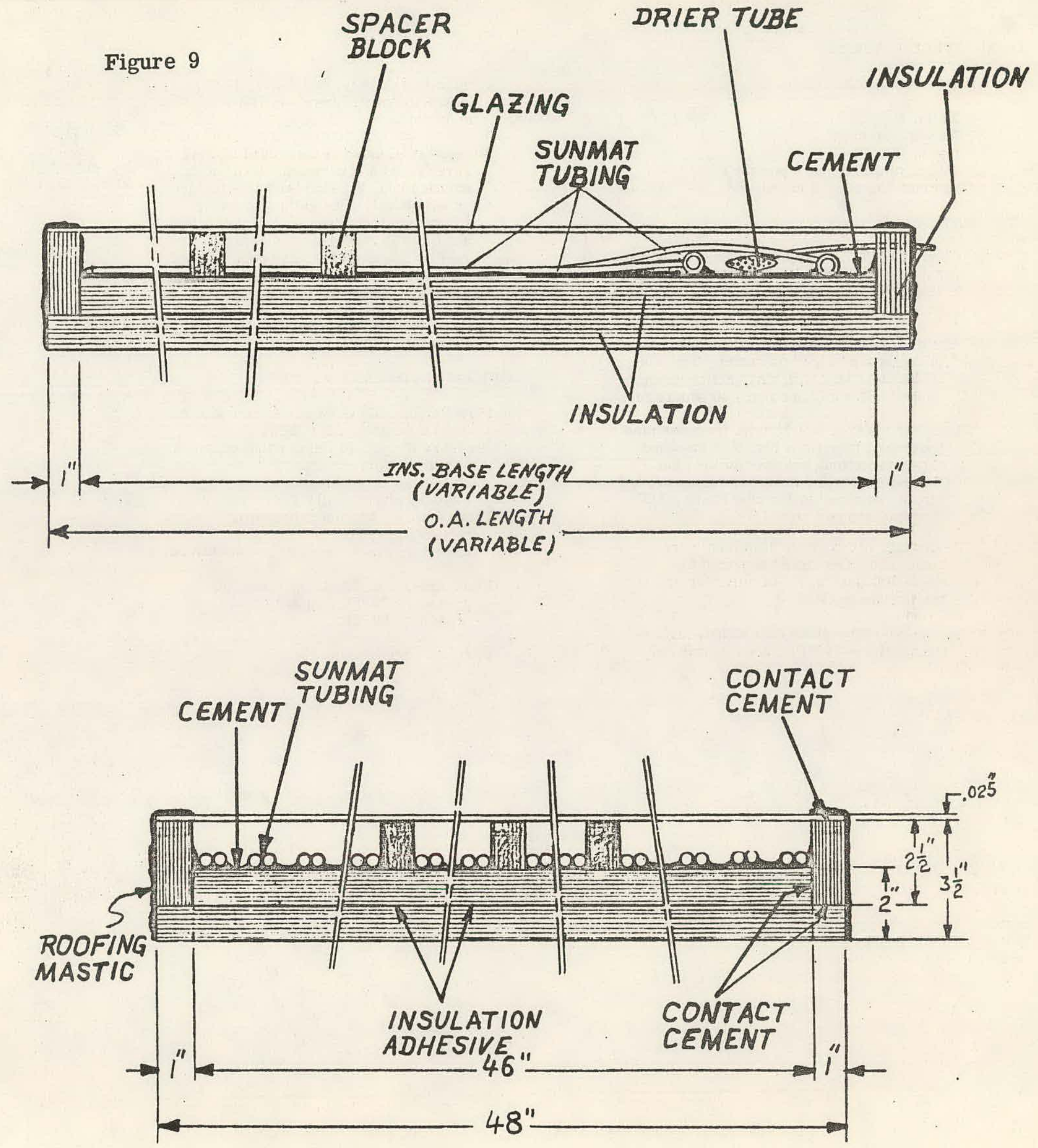


\section{SPECIFICATIONS}

\section{PHYSICAL DATA:}

Width: $4^{\prime}$

Length: Up to $50^{\prime}$

Depth: $31 / 2$ "

Weight (unfilled): 2.0 pounds $/ \mathrm{ft}^{2}$

Coolant Weight: .2 pounds $/ \mathrm{ft}^{2}$

\section{MATERIALS:}

Glazing: .025" guage fiberglass-reinforced polyester. $88 \%$ solar transmittance at $0^{\circ}$, $78 \%$ at $45^{\circ}$. Kalwall SUN-LITE Premium II or equivalent.

Absorber: 5/16" OD, 3/16" ID EPDM dual tubing spaced $11 / 2^{\prime \prime}$ on center bonded to insulation board with CAL-ZORB urethane cement. One gallon covers 40 square feet.

Headers: $3 / 4^{\prime \prime}$ x 42 1/2" type L copper pipe. External connections are $3 / 4^{\prime \prime}$ threaded pipe connections soldered to the pipe. Connections to the absorber tubing are $1 / 4^{\prime \prime}$ nipples soldered to the pipe every $13 / 8^{\prime \prime}$. Two headers per mat.

Desiccant: Silica gel in aluminum wire mesh tube. One dryer required for every 200 square feet of collector or fraction thereof.

Insulation: Fiberglass duct board, high temperature $\left(350^{\circ} \mathrm{F}\right)$, three pounds per cubic foot density, foil-faced, l" thick. Owens-Corning Fiberglass 703 or equivalent.

Adhesives: Contact cement used to bond cover panel and perimeter walls to insulation bed, 3M 1300 Rubber Adhesive or equivalent. One gallon for every 130 square feet of collector. Adhesive used to waterproof the collector, roofing mastic. Adhesive used to bond insulation together, Foster 85-15 Stic-Safe Adhesive.

Coolant: Water or mixture of glycol and water. .03 gallons per square foot.

\section{OPERATING DATA:}

Flow Rates: .018 GPM per square foot of mat, minimum of $2.0 \mathrm{GPM}$.

Pressure Drop: . 16 PSI per foot of length of mat, water. .2 PSI per foot of length of mat, $40 \%$ ethylene glycol at $100^{\circ} \mathrm{F}$.

Temperature: Maximum operating temperature, $210^{\circ} \mathrm{F}$. Maximum allowable tubing temperature, $350^{\circ} \mathrm{F}$.

Fluid Pressure: Maximum operating pressure, 20PSI. Tubing burst pressure, 80PSI.

$\mathrm{F}_{\mathrm{R}} \mathrm{U}_{\mathrm{L}}: \quad .86$

$\mathrm{F}_{\mathrm{R}}(\mathrm{Ta})_{\mathrm{n}}: .67$ 
COLLECTOR SIZING GUIDE 
THIS PAGE

\section{WAS INTENTIONALLY LEFT BLANK}




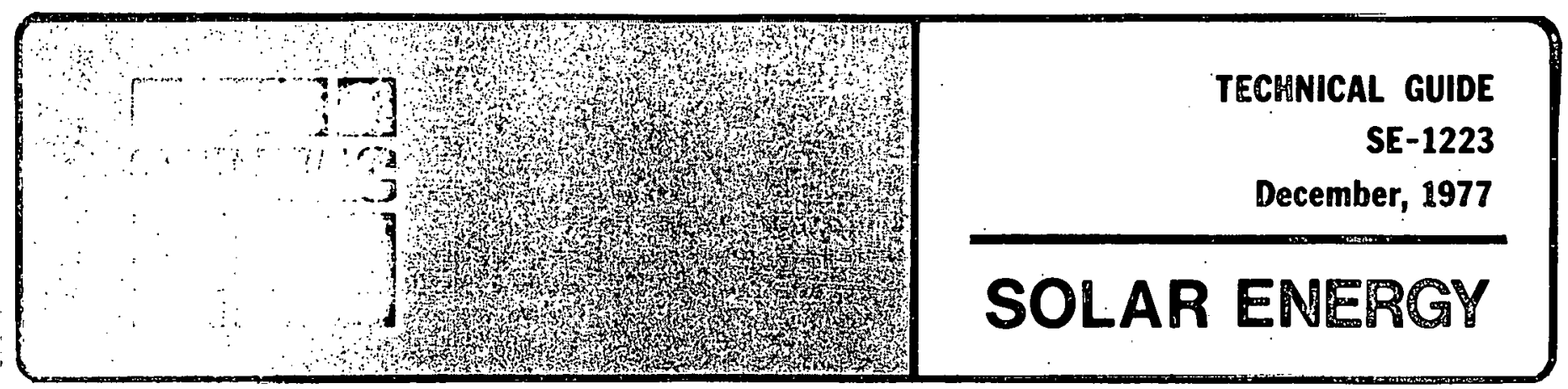

\section{Collector Sizing Guide For Solar Energy Systems}

A. Sizing of Conventional v8. Solar Systems

Determining the optimum size for a solar collector is an economic decision as well as a technical one. In this respect the job of sizing a solar system is somewhat different from the job of sizing a conventional heating or air conditioning system. Conventional heating or air conditioning systems are sized by determining the capacity required to meet the peak demands of design conditions--since the equipment is the only source of heating and cooling and is expected to provide adequate performance at the extremes of expected conditions. Solar systems, on the other hand, operate in conjunction with backup systems, which take up the load under extreme conditions that the solar system cannot handle.

The sizing question is not "How much capacity is needed to handle $100 \%$ of the load?" as it is with conventional equipment, but rather two questions: "How much of the capacity should the solar system provide?" and "How big a system is required to provide that portion of the capacity?"

The first of these two questions is the key one and it is an economic one. Solar systems in- volve high initial capital costs and low operating costs, and the capital costs are paid for out of the energy costs saved every day the equipment is used. The optimum amount of solar capacity to install is therefore the amount that will recover the initial costs out of lowered operating costs as quickly as possible. From this standpoint excess solar capacity is uneconomic--excess capacity is capacity that is not being used, and capacity that is not being used, is not saving energy and paying for itself. As a result, optimally sized solar equipment generally should provide about $50 \%$ of the total annual energy requirements for most applications.

The methods described in this manual for sizing solar systems provide a rapid, practical means of estimating heating load requirements and the solar contribution to that heating requirement. Other, more sophisticated methods, some using computer analysis, are available and may be used, but the methods described here are accurate enough for most applications. The SUNMAT Collector efficiency data included in the Specifications section should be used when further analysis is indicated. 
B. Determining the Heating Load

1. Determining the total heating requirement is the first step in sizing the solar system.

a. Domestic Hot Water. The amount of heat required to produce hot water for a home depends on the temperature of the incoming water, and the amount of water used.

Table A illustrates typical monthly temperatures of water in domestic supply mains and can be used as a guide in determining the incoming temperature. Local water suppliers can provide more accurate data for spec if ic locations.

The U.S. Department of Commerce has compiled estimates of how much hot water an average household consumes in a variety of daily uses:

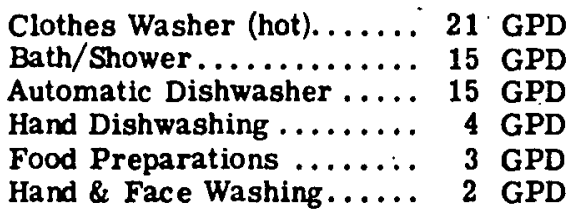

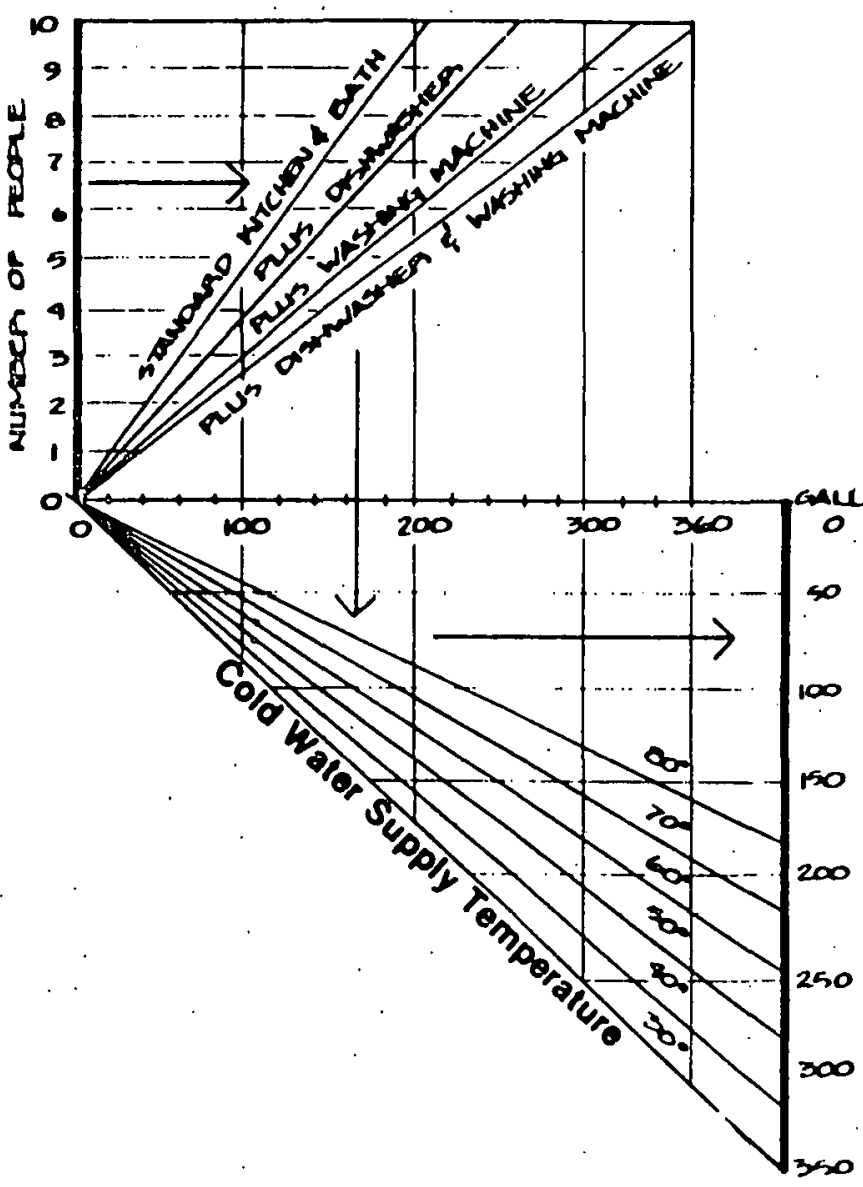

Month

January

February

March

April

May

June

July

August

September

October

November

December
HEATING

REQUI REMENTS

95,000 BTU/Day

94,000

90,000

75,000

70,000

60,000

55,000

62,000

65,000

70,000

80,000

80,000

Figure 1-2

On average a family uses $20-25$ gallons per person per day for bathing and cooking. To this must be added requirements for various appliances.

Use Figure 1-1 to estimale the domestic hot water heat requirements and fill in the estimates in Column $M$ of Table B. Figure 1-2 provides an example for a family of five located in Boston.

b. Space Heating. The amount of energy required to heat a home can be calculated in the conventional manner or by examining old fuel bills. However, as a rule of thumb it is also possible to estimate the heating load as 8 BTUs per degree-day per square foot of building. This is what the heat loss should be for a solar-heated home. If it is higher than this, additional insulation should be provided.

Complete Column $L$ and $M$ of -Table $C$ to determine the heating load on the building in question. Table D provides degree day estimates for all regions of the country.

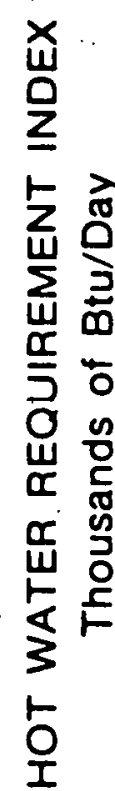


C. Determining the rollestor Size

1. The first step in sizing the collector is to determine the angle which the collector is to be tilted. The optimum tilt is that angle that spreads out the amount of sun that can be collected as evenly as possible over the entire period of intended use. In an application requiring year-round use, for example, this means an angle which allows full collection of the sun's weaker rays in the winter but misses some of the stronger rays in the summer. Figure 1-3 can be used as a guide in determining the optimum collector angle.

The collectors should also be installed facing as directly south as possible, although variations of up to $15^{\circ}$ will not have a significant impact on performance.

2. The next step in this process is to calculate the amount of energy that one square foot of collector can provide on an average day in each of the twelve months of the year. To do this complete Section I of Table B for Hot Water Heating and Table $C$ for Space Heating.

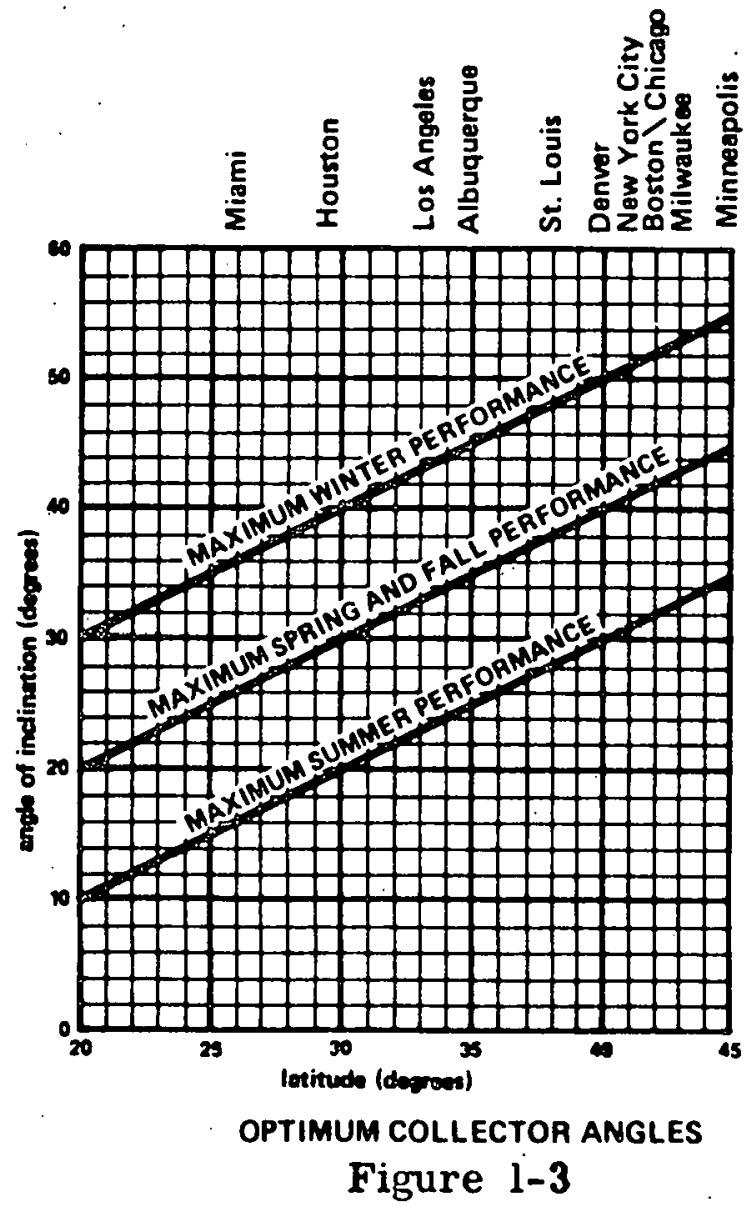

Usc Tables E, F and $G$ to fill in the necessary data on tilt factor, horizontal insolation, and average temperature. The Average Daytime Air Temperature is generally estimated at six degrees above the 24-hour average temperature. Then proceed to carry out the calculations necessary to complete Section II of the tables.

3. The last step in sizing the solar system involves determining the collector area required to meet the desired portion of the total annual load.

a. Domestic Hot Water. The solar system should be sized to provide 50 to $60 \%$ of the energy requirements for a domestic hot water system. To make a preliminary estimate of the amount of collector area required, divide the total heating requirement in the month of June by the amount of energy collected by one square foot of collect or in June. Then use this amount, which is the area required to provide $100 \%$ of the heat in June, as the estimate of the optimum size.

Then proceed to calculate how much energy the system will provide in the other 11 months by multiplying the amount of energy one square foot will collect by the number of square feet chosen.

To determine the percentage of the annual hot water heating requirement the solar system. will provide, amounts in excess of the a mounts needed must be lopped off. So enter in Column N, Usable Solar Energy, the lower of Columns $\mathrm{L}$ and $\mathrm{M}$.

Add up the total annual heating requirement (Column M) and the tot al Usable Solar Energy (Column L) and divide in order to determine. the percentage of total requirements provided by solar. If the percentage is not between $\mathbf{5 0}$ and $60 \%$ adjust the collector area and redo the calculations.

b. Space Heating. In a space heating application the economic size of the collector system is an area capable of providing roughly 40 to $50 \%$ of the total requirement. The method of determining the percentage of heat provided by the solar system is identical to the method used for domestic hot water heating, except that the initial estimate is made by dividing the total heating requirement in March by the amount of energy collected by one square foot of collector in March. 


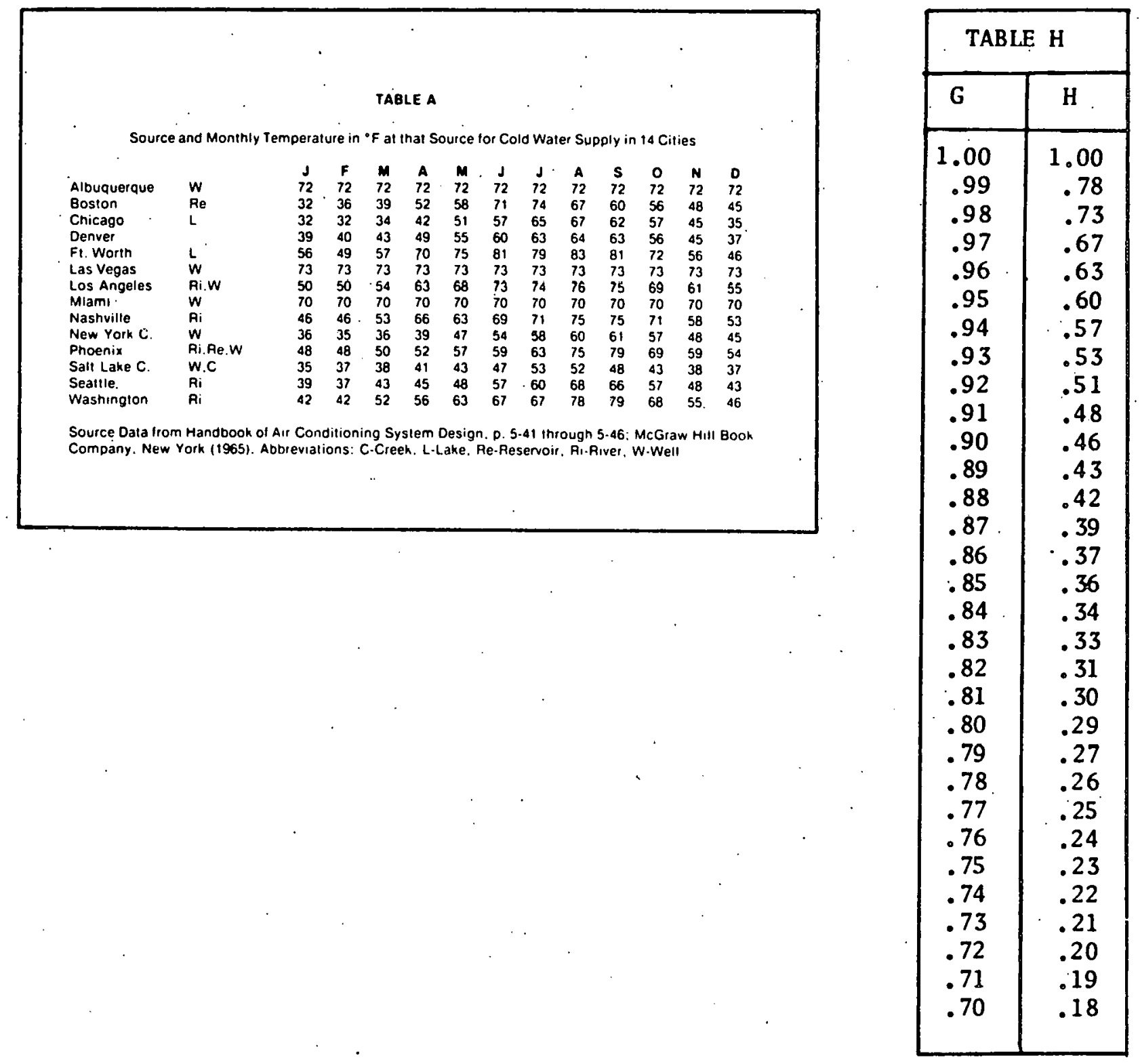


TABLE C

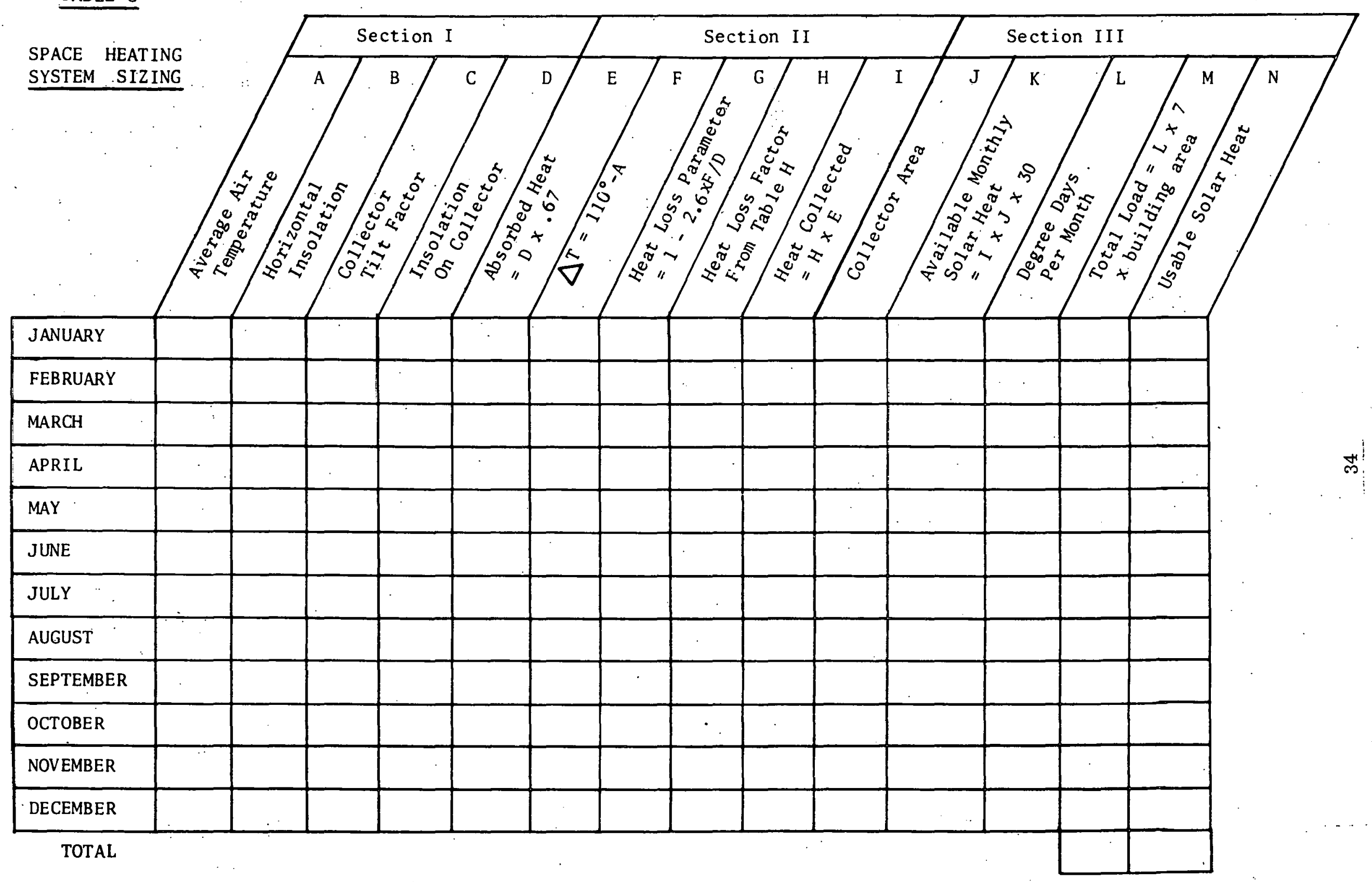


TABLE E

\section{COLLECTOR TILT FACTORS}

\begin{tabular}{|c|c|c|c|c|c|c|c|c|c|c|c|c|c|c|}
\hline & $\begin{array}{l}\text { Degrees } \\
\text { Latitude }\end{array}$ & $L-10$ & $\mathbf{L}$ & $L+10$ & $L+20$ & Vertical & & $\begin{array}{l}D \\
\text { L }\end{array}$ & $\begin{array}{l}\text { rees } \\
\text { tude }\end{array}$ & $L-10$. & L $L$ & $L+10$ & $L+20$ & Vertical \\
\hline \multirow[t]{6}{*}{ January 21} & 24 & 1.22 & 1.34 & 1.42 & 1.45 & 1.09 & & \multirow{6}{*}{ July 21} & & & & & & \\
\hline & 32 & 1.43 & 1.56 & 1.64 & 1.68 & 1.38 & & & 24 & 0.95 & 0.89 & 0.81 & 0.70 & 0.10 \\
\hline & 40 & 1.75 & $1.9 \mathrm{~J}$ & 2.01 & 2.05 & 1.82 & & & 32 & 0.95 & 0.88 & 0.79 & 0.69 & 0.18 \\
\hline & 48 & 2.27 & 2.47 & 2.59 & 2.64 & 2.47 & & & 40 & 0.95 & 0.95 & 0.79 & 0.68 & 0.28 \\
\hline & 56 & 3.31 & 3.58 & 3.75 & 3.81 & 3.70 & & & 48 & 0.96 & 0.89 & 0.80 & 0.68 & 0.39 \\
\hline & 64 & 5.96 & 6.44 & 6.71 & 6.8 & 6.76 & & & 56 & 0.99 & 0.91 & 0.81 & 0.69 & .0 .50 \\
\hline \multirow[t]{7}{*}{ February 21} & 24 & 1.14 & 1.20 & 1.22 & 1.21 & 0.75 & & \multirow{7}{*}{ August 21} & & & & & & 0.02 \\
\hline & 32 & 1.27 & 1.33 & 1.36 & 1.35 & 0.05 & & & 24 & 1.00 & 0.96 & 0.98 & 0.81 & $0.20=$ \\
\hline & 40 & 1.46 & 1.53 & 1.56 & 1.54 & 1.22 & & & 32 & 1.02 & 0.98 & 0.91 & 0.82 & 0.31 \\
\hline & 48 & 1.74 & 1.83 & 1.87 & 1.83 & 1.59 & & & 40 & 1.05 & 1.01 & 0.94 & 0.84 & 0.44 \\
\hline & 56 & 2.22 & 2.32 & 2.42 & 2.32 & 2.16 & & & 48 & 1.10 & 1.05 & 0.98 & 0.88 & 0.58 \\
\hline & 64 & 3.08 & 3.22 & 3.26 & 3.21 & 3.13 & & & 56 & 1.18 & 1.12 & 1.04 & 0.93 & 0.74 \\
\hline & & & & & & & & & 64 & 1.28 & 0.61 & 1.13 & 1.01 & 0.92 \\
\hline \multirow{3}{*}{ March 21} & 24 & 1.07 & 1.08 & 1.06 & 1.01 & 0.45 & & \multirow{7}{*}{ September 21} & & & & & & \\
\hline & 32 & 1.14 & 1.15 & 1.13 & 1.08 & 0.61 & $\cdot$ & & 24 & 1.11 & 1.08 & 1.06 & 1.01 & 0.45 \\
\hline & 40 & 1.25 & 1.26 & $1.23^{i}$ & 1.17 & 0.80 & & & 32 & 1.14 & 1.15 & 1.12 & 1.07 & 0.61 \\
\hline - & 48 & 1.19 & 1.20 & 1.18 & 1.12 & 0.88 & & & 40 & 1.24 & 1.25 & 1.22 & 1.16 & 0.79 \\
\hline & 56 & 1.63 & 1.64 & 1.61 & 1.53 & 1.34 & & & 48 & 1.38 & 1.39 & 1.36 & 1.29 & 1.02 \\
\hline & 64 & 1.99 & 2.01 & 1.96 & 1.86 & 1.78 & & & 56 & 1.60 & 1.61 & 1.57 & 1.49 & 1.31 \\
\hline \multirow{7}{*}{ April 21} & & & & & & & & & 64 & 1.93 & 2.17 & 1.90 & 1.80 & 1.72 \\
\hline & 32 & 1.00 & 0.96 & 0.90 & $\begin{array}{l}0.02 \\
0.81\end{array}$ & 0.31 & & \multirow[t]{6}{*}{ October 21} & 24 & .1 .14 & 1.20 & 1.23 & 1.22 & 0.75 \\
\hline & 40 & 1.06 & 1.02 & 0.95 & 0.86 & 0.45 & & & 32 & 1.27 & $1: 33$ & 1.36 & 1.35 & 0.96 \\
\hline & 48 & 1.12 & 1.08 & 1.00 & 0.93 & 0.60 & & & 40 & 1.46 & 1.53 & 1.56 & 1.54 & 1.23 \\
\hline & 56 & 1.21 & 1.16 & 1.08 & 0.97 & 0.77 & & & 48 & 1.74 & 1.82 & 1.85 & 1.83 & 1.59 \\
\hline & 64 & 1.69 & 1.27 & 1.18 & 1.06 & 0.97 & & & 56 & 2.20 & 2.31 & 2.34 & 2.31 & 2.15 \\
\hline & & & & & & & & & 64 & 3.04 & 3.17 & 3.22 & 3.17 & 3.09 \\
\hline \multirow[t]{6}{*}{ May 21} & 24 & 0.96 & 0.89 & 0.81 & $\begin{array}{l}0.70 \\
0.70\end{array}$ & $\begin{array}{l}0.10 \\
0.10\end{array}$ & & \multirow{6}{*}{ November 21} & 24 & 1.22 & 1.33 & 1.41 & 1.44 & 1.07 \\
\hline & $\begin{array}{l}32 \\
32\end{array}$ & $\begin{array}{l}0.96 \\
0.95\end{array}$ & $\begin{array}{l}0.89 \\
0.88\end{array}$ & $\begin{array}{l}0.81 \\
0.80\end{array}$ & 0.69 & 0.18 & & & 32 & 1.42 & 1.55 & 1.63 & 1.66 & 1.36 \\
\hline & 40 & 0.96 & 0.89 & 0.80 & 0.69 & 0.28 & & & 40 & 1.74 & 1.89 & 1.99 & 2.03 & 1.79 \\
\hline & 48 & 0.97 & 0.90 & 0.81 & 0.70 & 0.40 & & & 48 & 2.24 & 2.43 & 2.55 & 2.59 & 2.42 \\
\hline & 56 & 1.00 & 0.92 & 0.83 & 0.71 & 0.51 & & & 56 & 3.22 & 3.47 & 3.63 & 3.68 & 3.58 \\
\hline & 64 & 1.03 & 0.95 & 0.85 & 0.73 & 0.64 & & & 64 & 5.78 & 6.22 & 6.48 & 6.57 & 6.52 \\
\hline \multirow[t]{6}{*}{ June 21} & 24 & 0.94 & 0.87 & 0.77 & 0.66 & 0.08 & & \multirow[t]{6}{*}{ December 21} & 24 & 1.26 & 1.40 & 1.50 & 1.55 & 1.23 \\
\hline & 32 & 0.92 & 0.85 & 0.76 & 0.64 & 0.14 & & & 32 & 1.50 & 1.66 & 1.77 & 1.84 & 1.58 \\
\hline & 40 & 0.92 & 0.84 & 0.75 & 0.63 & 0.23 & & & 40 & 1.89 & 2.09 & 2.23 & 2.30 & 2.10 \\
\hline & 48 & 0.92 & 0.92 & 0.74 & 0.63 & 0.33 & & & 48 & 2.55 & 2.80 & 2.97 & 3.06 & 2.92 \\
\hline & 56 & 0.93 & 0.85 & 0.75 & 0.63 & 0.44 & & & 56 & 3.95 & 4.32 & 4.56 & 4.68 & 4.60 \\
\hline & 64 & 0.94 & 0.85 & 0.75 & 0.63 & 0.55 & & & 64 & 10.0 & 11.0 & 12.0 & 12.0 & 12.0 \\
\hline
\end{tabular}


TABLE
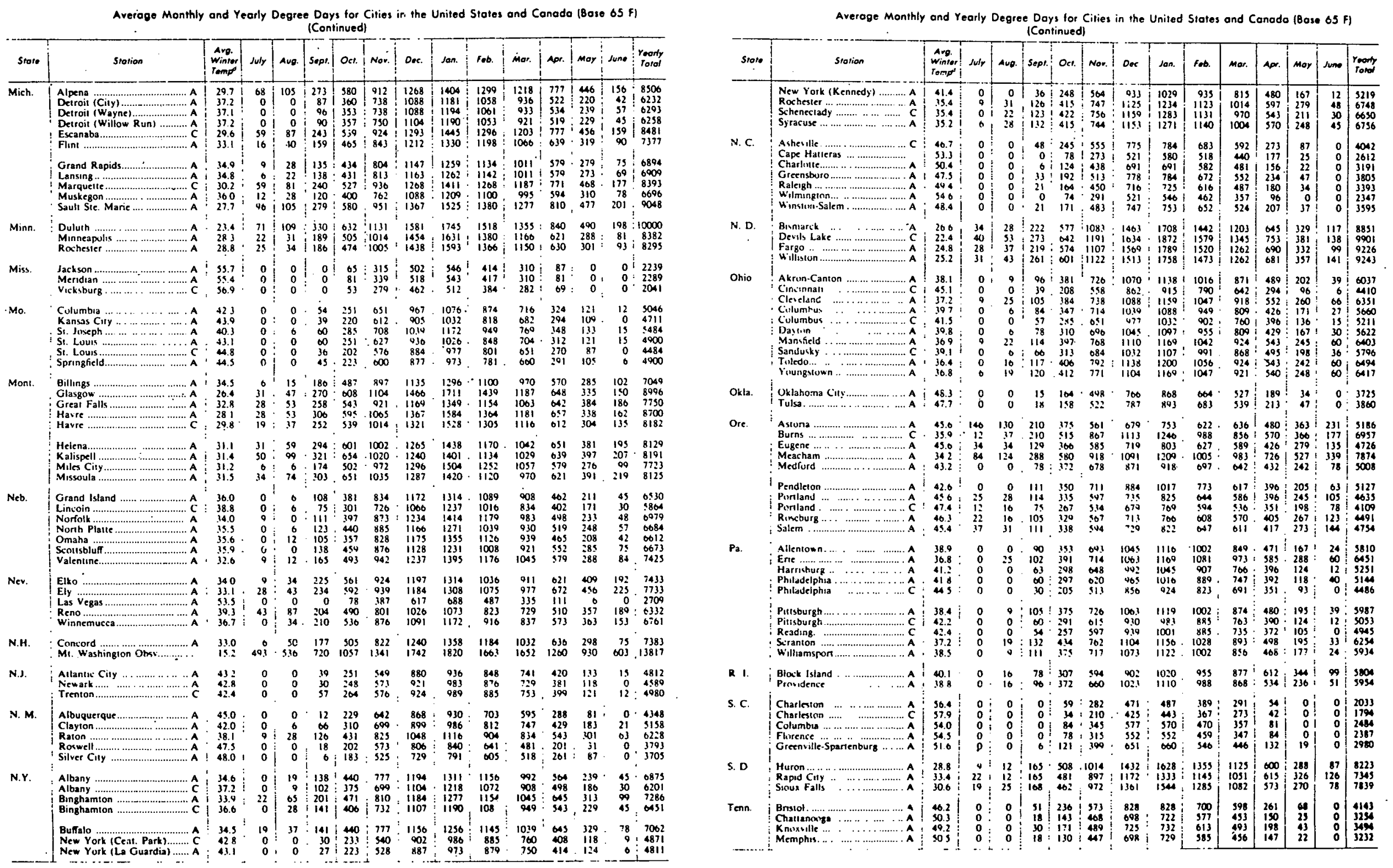

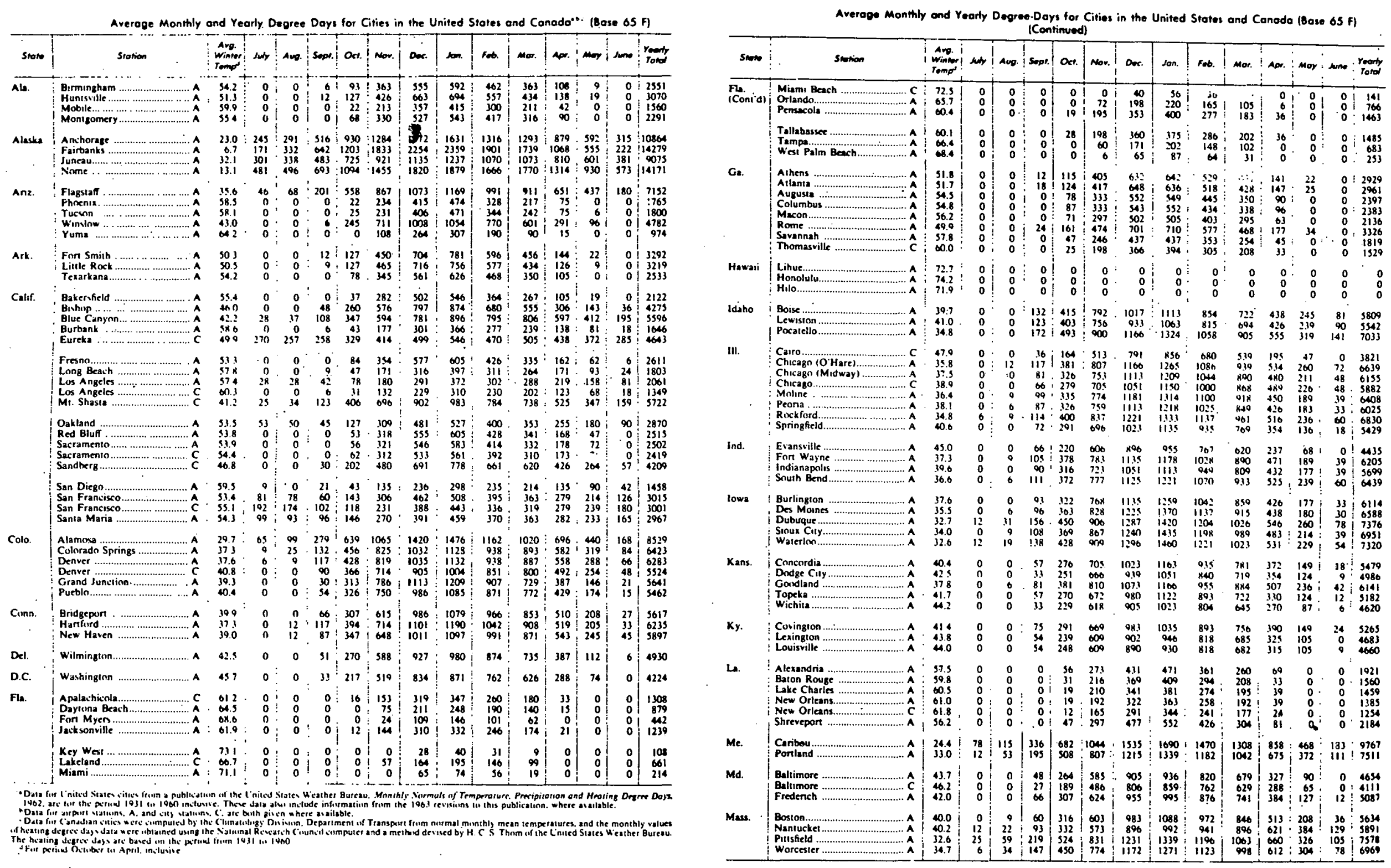


\begin{tabular}{|c|c|c|c|c|c|c|c|c|c|c|c|c|c|c|c|}
\hline $\begin{array}{l}\text { Srow } \\
\text { porer. }\end{array}$ & Stration & 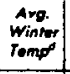 & sur & Ano. & 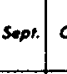 & oct. $\mid 1$ & Nov. & $D_{\text {orc. }}$ & tan. & fob. & mar. & Ape. & mar! & June : & 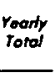 \\
\hline \multirow{11}{*}{ Tex. } & 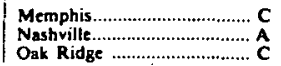 & $\begin{array}{l}35.6 \\
48.9 \\
47.9\end{array}$ & $\begin{array}{l}0 \\
0 \\
0\end{array}$ & $\begin{array}{l}0 \\
0 \\
0\end{array}$ & $\begin{array}{llll}12 & 12 \\
39 & 1\end{array}$ & $\begin{array}{l}102 \\
198 \\
192\end{array}$ & $\begin{array}{l}396 \\
495 \\
531\end{array}$ & $\begin{array}{l}6.98 \\
7.72 \\
772\end{array}$ & $\begin{array}{l}770 \\
778 \\
778\end{array}$ & . & $\begin{array}{l}434 \\
312 \\
552\end{array}$ & $\begin{array}{l}129 \\
189 \\
228\end{array}$ & $\begin{array}{l}16 \\
40 \\
36\end{array}$ & | & $\begin{array}{l}3015 \\
318 \\
3817\end{array}$ \\
\hline & $\begin{array}{l}\text { Abilene. } \\
\text { Amanilo........... }\end{array}$ & $\begin{array}{l}53.9 \\
47.0\end{array}$ & $: 0$ & : & $\begin{array}{ll}0 & 0 \\
18 & 2\end{array}$ & $\begin{array}{c}909 \\
205\end{array}$ & 350 & $\begin{array}{l}586 \\
797\end{array}$ & 思2 & $\begin{array}{l}470 \\
604\end{array}$ & $\begin{array}{l}3476 \\
546\end{array}$ & $\begin{array}{l}114 \\
252\end{array}$ & $\begin{array}{c}0 \\
50\end{array}$ & : & ${ }_{3985}^{2624}-x-100$ \\
\hline & 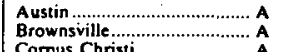 & $\begin{array}{l}59.1 \\
67.7\end{array}$ & & $\begin{array}{c}0 \\
0\end{array}$ & \begin{tabular}{r|r|}
0 \\
0
\end{tabular} & $\begin{array}{cc}31 \\
0 \\
0\end{array}$ & $\begin{array}{l}225 \\
606\end{array}$ & $\begin{array}{l}388 \\
149\end{array}$ & 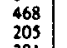 & $\begin{array}{l}325 \\
106 \\
104\end{array}$ & $\begin{array}{l}223 \\
76 !\end{array}$ & si & $\begin{array}{l}0 \\
0 \\
0\end{array}$ & 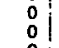 & $\begin{array}{l}771 \\
600 \\
600\end{array}$ \\
\hline & 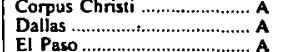 & 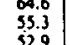 & $\begin{array}{c}0 \\
0 \\
0\end{array}$ & $\begin{array}{l}0 \\
0 \\
0\end{array}$ & $\begin{array}{r}0 \\
0 \\
0\end{array}$ & $\begin{array}{c}0 \\
62 \\
24\end{array}$ & 热1 & 200 & $\begin{array}{l}291 \\
601 \\
0.85\end{array}$ & $\begin{array}{r}174 \\
440 \\
49\end{array}$ & $\begin{array}{l}109 \\
319 \\
319\end{array}$ & $\begin{array}{c}90 \\
100 \\
100\end{array}$ & $\begin{array}{c}0 \\
6 \\
0\end{array}$ & : & 20300 \\
\hline & Worth. & & & & 0 & 63 & & & & & & 99 & & & 2008 \\
\hline & vestion... & $\begin{array}{l}62.2 \\
62.0\end{array}$ & $\stackrel{0}{n}$ & $\begin{array}{l}0 \\
0\end{array}$ & $\begin{array}{r}0 \\
0 \\
0\end{array}$ & $\begin{array}{l}6 \\
0\end{array}$ & $\begin{array}{l}147 \\
138\end{array}$ & 270 & $\begin{array}{l}360 \\
350 \\
300\end{array}$ & $\begin{array}{l}263 \\
258\end{array}$ & $\begin{array}{l}189 \\
189\end{array}$ & 33 & $\begin{array}{l}0 \\
0\end{array}$ & & $\begin{array}{l}1274 \\
1235\end{array}$ \\
\hline & $\begin{array}{l}\text { Houssion. } \\
\text { Houston : }\end{array}$ & $\begin{array}{l}61.0 \\
62.0\end{array}$ & & : & $\begin{array}{l}0 \\
0\end{array}$ & $\begin{array}{l}6 \\
0\end{array}$ & $\begin{array}{l}183 \\
183 \\
103\end{array}$ & $\begin{array}{l}307 \\
288\end{array}$ & $\begin{array}{l}384 \\
363\end{array}$ & $\begin{array}{l}2889 \\
288^{2}\end{array}$ & & & $\begin{array}{c}0 \\
0\end{array}$ & & 1396 \\
\hline & $\begin{array}{l}\text { Laredo .... } \\
\text { Lutbock.... }\end{array}$ & $\begin{array}{l}66.0 \\
48.8\end{array}$ & $\begin{array}{l}0 \\
0\end{array}$ & $:$ & $\begin{array}{c}0 \\
18\end{array}$ & $\begin{array}{r}174 \\
\end{array}$ & $\begin{array}{l}105 \\
S_{13}\end{array}$ & 年 & 800 & $\begin{array}{l}134 \\
613 \\
613\end{array}$ & $\begin{array}{r}78 \\
484\end{array}$ & $\begin{array}{rl}20 & 0\end{array}$ & $\begin{aligned} 0 \\
01\end{aligned}$ & 0 & $\begin{array}{l}797 \\
3598 \\
3\end{array}$ \\
\hline & $\begin{array}{l}\text { Midalad...... } \\
\text { Porn Artur. }\end{array}$ & $\begin{array}{l}53.8 . \\
60.5\end{array}$ & $: 0$ & $\stackrel{0}{0}$ & $\begin{array}{l}0 \\
0 \\
0\end{array} \mid-1-1$ & $\begin{array}{l}87 \\
22\end{array}$ & $\begin{array}{l}381 \\
207\end{array}$ & $\begin{array}{l}592 \\
329\end{array}$ & 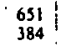 & 274 & $\begin{array}{l}322 \\
1322\end{array}$ & $\begin{array}{c}90 \\
39\end{array}$ & $:$ & 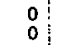 & $\begin{array}{l}2391 \\
1497\end{array}$ \\
\hline & 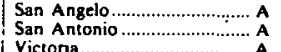 & $\begin{array}{l}56.0 \\
60.1\end{array}$ & $\begin{array}{c}0 \\
0 \\
0\end{array}$ & $\begin{array}{l}0 \\
0\end{array}$ & $\begin{array}{c}0 \\
0 \\
0\end{array} \mid$ & 然 & 206 & $\begin{array}{llll}536 \\
363\end{array}$ & $\begin{array}{l}967 \\
28\end{array}$ & $\begin{array}{l}412 \\
286 \\
286\end{array}$ & 195 288 & 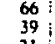 & 0 & 0 & $\begin{array}{l}2253 \\
1546\end{array}$ \\
\hline & 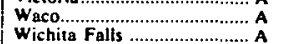 & $\begin{array}{ll}57.2 \\
53.2\end{array}$ & 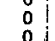 & 8 & $\begin{array}{l}0 \\
0 \\
0\end{array}$ & . & $\begin{array}{l}270 \\
270 \\
381\end{array}$ & 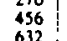 & 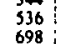 & 势8 & $\begin{array}{l}270 \\
278 \\
38\end{array}$ & $\begin{array}{l}160 \\
160\end{array}$ & : & 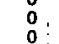 & $\begin{array}{l}2730 \\
2030 \\
282\end{array}-3$ \\
\hline \multirow[t]{2}{*}{ Uetah } & $\mathrm{Mi}$ & & & 0 & 99 & & & & 1232 & 988 & 822 & 919 & 279 & & \\
\hline & $\begin{array}{l}\text { Sastit Lake city } \\
\text { Wendover ? }\end{array}$ & 39.4 & $\begin{array}{c}0 \\
0\end{array}$ & $:$ & . & $\begin{array}{l}449 \\
372\end{array}$ & 82.2 & $\begin{array}{l}1802 \\
1091\end{array}$ & $\begin{array}{l}1172 \\
1178\end{array}$ & .990 & 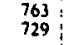 & $\begin{array}{l}459 \\
408\end{array}$ & 233 & 84 & $\begin{array}{l}6052 \\
578\end{array}$ \\
\hline$v_{t}$. & Burlingion ...................... & 29.4 & 28 & 65 & 207 & $\$ 39$ & 891 & 1349 & 1513 & 1333 & 1187 & 714 & 353 & 90 & 8269 \\
\hline \multirow[t]{2}{*}{ 年 } & 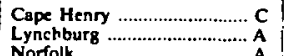 & $\begin{array}{l}50.0 \\
46.0\end{array}$ & 0 & $\begin{array}{l}0 \\
0 \\
0\end{array}$ & si & $\begin{array}{l}112 \\
2123\end{array}$ & $\begin{array}{l}360 \\
300 \\
500\end{array}$ & $\begin{array}{l}645 \\
822\end{array}$ & $\begin{array}{l}694 \\
849\end{array}$ & $\begin{array}{l}633 \\
731\end{array}$ & $\begin{array}{l}536 \\
605 \\
621\end{array}$ & $\begin{array}{l}246 \\
267\end{array}$ & $\begin{array}{l}53 \\
78 \\
77\end{array}$ & 0 & $\begin{array}{l}3279 \\
4166\end{array}$ \\
\hline & $\begin{array}{l}\text { Rortolk.......... } \\
\text { Roanote ............ }\end{array}$ & $\begin{array}{l}49.2 \\
4.3 .1\end{array}$ & $\begin{array}{l}0 \\
\vdots \\
0\end{array}$ & \begin{tabular}{l|l}
0 & \\
0 &
\end{tabular} & $\begin{array}{ll}36 & 0 \\
31 & 2\end{array}$ & $\begin{array}{l}214 \\
229\end{array}$ & 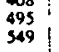 & $\begin{array}{l}\text { Ty8 } \\
784 \\
825\end{array}$ & $\begin{array}{l}78 \\
845\end{array}$ & $\begin{array}{l}7032 \\
722 .\end{array}$ & 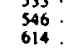 & $\begin{array}{l}219 \\
219 \\
261\end{array}$ & $\begin{array}{l}313 \\
63\end{array}$ & 0. & $\begin{array}{l}384 \\
3850 \\
4150\end{array}$ \\
\hline \multirow[t]{3}{*}{ as } & $\begin{array}{l}\text { Olympia ............. } \\
\text { Seatle-Tacoma.. }\end{array}$ & 44.2 & $\mid$ & $\begin{array}{l}71 \\
62\end{array}$ & $\begin{array}{l}198 \\
192 \\
162\end{array}$ & $\begin{array}{l}422 \\
391\end{array}$ & 636 633 & 733 & 834 & 678: & 6045 & 勇 50 & $\begin{array}{l}307 \\
209\end{array}$ & 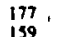 & $\begin{array}{l}5236 \\
9145\end{array}$ \\
\hline & $\begin{array}{l}\text { Sen } \\
\text { so } \\
\text { so }\end{array}$ & 36.9. 40.9 & $\stackrel{50}{9}$ & $\begin{array}{l}45 \\
25\end{array}$ & | 168 & 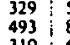 & 879 & $\begin{array}{r}6057 \\
1082\end{array}$ & 1231 & $\begin{array}{l}599 \\
980\end{array}$ & 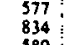 & 396: & 288 & 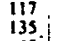 & 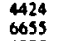 \\
\hline & $\begin{array}{l}\text { Walla Walla. } \\
\text { Yakima a..... }\end{array}$ & $\begin{array}{l}4.8 .1 \\
39.1\end{array}$ & & .12 & & $\begin{array}{l}310 \\
450\end{array}$ & 828 & $\begin{array}{l}8039 \\
1039\end{array}$ & $\begin{array}{l}1866 \\
1163\end{array}$ & 888. & 染13 & 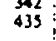 & 220 & 69. & $\begin{array}{l}8091 \\
3841\end{array}$ \\
\hline & 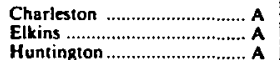 & $\begin{array}{l}44.8 \\
40.1\end{array}$ & 年 & $\begin{array}{c}0 \\
25\end{array}$ & $\begin{array}{l}63 \\
135 \\
38\end{array}$ & $\begin{array}{l}254 \\
400 \\
207\end{array}$ & $\begin{array}{l}591 \\
729\end{array}$ & $\begin{array}{l}805 \\
.922 \\
936\end{array}$ & $\begin{array}{l}880 \\
1008 \\
108\end{array}$ & $770:$ & 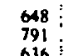 & 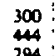 & 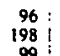 & $\begin{array}{c}9 \\
48 \\
4\end{array}$ & $\begin{array}{l}4776 \\
5075 \\
6046\end{array}$ \\
\hline & recrsbur & 43.5 & 0 & & $\infty$ & 264 & 600 & 905 & 942 & 826 & 691 & & 115 & & 154 \\
\hline & $\begin{array}{l}\text { Gracen Bay. } \\
\text { La coss... }\end{array}$ & $\begin{array}{l}30.3 \\
31.5 \\
309\end{array}$ & 年 & $\begin{array}{l}30 \\
19 \\
90\end{array}$ & 1.74: & 年4 & $\begin{array}{l}924 \\
9924 \\
992\end{array}$ & 1339 & $\begin{array}{l}1949 \\
1504\end{array}$ & 1327 & $\begin{array}{l}141 \\
11070 \\
070\end{array}$ & $\begin{array}{l}640 \\
5400 !\end{array}$ & $\begin{array}{l}335 \\
245 \\
245\end{array}$ & 69 & $\begin{array}{l}8599 \\
7589\end{array}$ \\
\hline & Milwaukee & 32.6 & 43 & 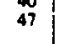 & 1748 & 471 & 年76 & $1252 !$ & 年376 & 1193 & $\begin{array}{l}1054 \\
1054\end{array}$ & . & 372 & 135 & 7635 \\
\hline \multirow[t]{2}{*}{ Wyo } & $\begin{array}{l}\text { Casper..... } \\
\text { Cheyenne. }\end{array}$ & $\begin{array}{l}33.4 \\
34.2\end{array}$ & $\begin{array}{l}68 \\
28\end{array}$ & 年 16 & 2192 & 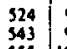 & $\begin{array}{l}942 \\
909\end{array}$ & $\begin{array}{lll}.1698 \\
1085\end{array}$ & 1290 & 1084 & $\begin{array}{l}1020 \\
1026 \\
1026\end{array}$ & $\begin{array}{l}6957 \\
702 \\
-102\end{array}$ & \$481 381 & $\begin{array}{l}{[29} \\
120\end{array}$ & $\begin{array}{l}7410 \\
7381\end{array}$ \\
\hline & $\begin{array}{l}\text { Lander } \\
\text { Shenidan............ }\end{array}$ & $\begin{array}{l}31.4 \\
32.5 \\
\end{array}$ & 25 & 31 & 2 & $\begin{array}{l}535 \\
399\end{array}$ & $\begin{array}{l}1020 \\
988 \\
98\end{array}$ & $\begin{array}{l}1290 \\
1200\end{array}$ & 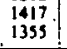 & $\begin{array}{l}\text { iitis } \\
1145\end{array}$ & $\begin{array}{l}1007 \\
10: 1 \\
10: 1\end{array}$ & 整2 & 386 & iso! 150 ; & 7680 \\
\hline \multirow[t]{5}{*}{ Alts } & 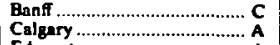 & $=$ & $\begin{array}{l}220 \\
109\end{array}$ & 186 & $\begin{array}{l}498 \\
002\end{array}$ & 7979 & & $\begin{array}{l}1483 \\
1389\end{array}$ & & 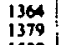 & & 898 & (989. & $\begin{array}{l}402 \\
2014\end{array}$ & 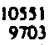 \\
\hline & Lethbridge -........................ & & 36 & $\mid \begin{array}{l}180 \\
112\end{array}$ & $\mid \begin{array}{l}1118 \\
318\end{array}$ & 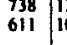 & & | & | & $\mid$ & $\begin{array}{l}1330 \\
1159\end{array}$ & $\begin{array}{l}7656 \\
696\end{array}$ & 003 & 213 ! & 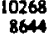 \\
\hline & $\begin{array}{l}\text { Karmloops } \\
\text { Prince George" }\end{array}$ & $=$ & ${ }_{236}^{22}$ & 230 & 189 & $\begin{array}{l}546 \\
747\end{array}$ & 894 & $\begin{array}{l}\prod_{1438}^{1480} \\
140\end{array}$ & $\begin{array}{l}1314 \\
1612\end{array}$ & $\begin{array}{l}1037 \\
1319\end{array}$ & $\begin{array}{r}818 \\
11122 \\
\end{array}$ & $\begin{array}{l}462 \\
147\end{array}$ & 168 217 & 102! ! & 6999 \\
\hline & & $\bar{z}$ & $\begin{array}{l}273 \\
81 \\
13\end{array}$ & $\begin{array}{l}248 \\
87\end{array}$ & $\begin{array}{l}339 \\
219 \\
232\end{array}$ & $\begin{array}{l}939 \\
456 \\
446\end{array}$ & $\begin{array}{l}708 \\
637\end{array}$ & 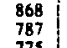 & 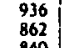 & 然2 208 & $\begin{array}{l}882 \\
676 \\
676\end{array}$ & 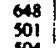 & $\begin{array}{l}493 \\
310 \\
30\end{array}$ & $\begin{array}{l}3156 \\
136 \\
\end{array}$ & 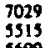 \\
\hline & & $=$ & 136 & $\begin{array}{l}190 \\
184 \\
\end{array}$ & & \begin{tabular}{l|l}
$4{ }_{426}^{462}$ & 8 \\
\end{tabular} & & & & & $\begin{array}{l}\infty 691 ! \\
600 !\end{array}$ & $\begin{array}{l}504 ! \\
487 !\end{array}$ & & 250 & \\
\hline
\end{tabular}

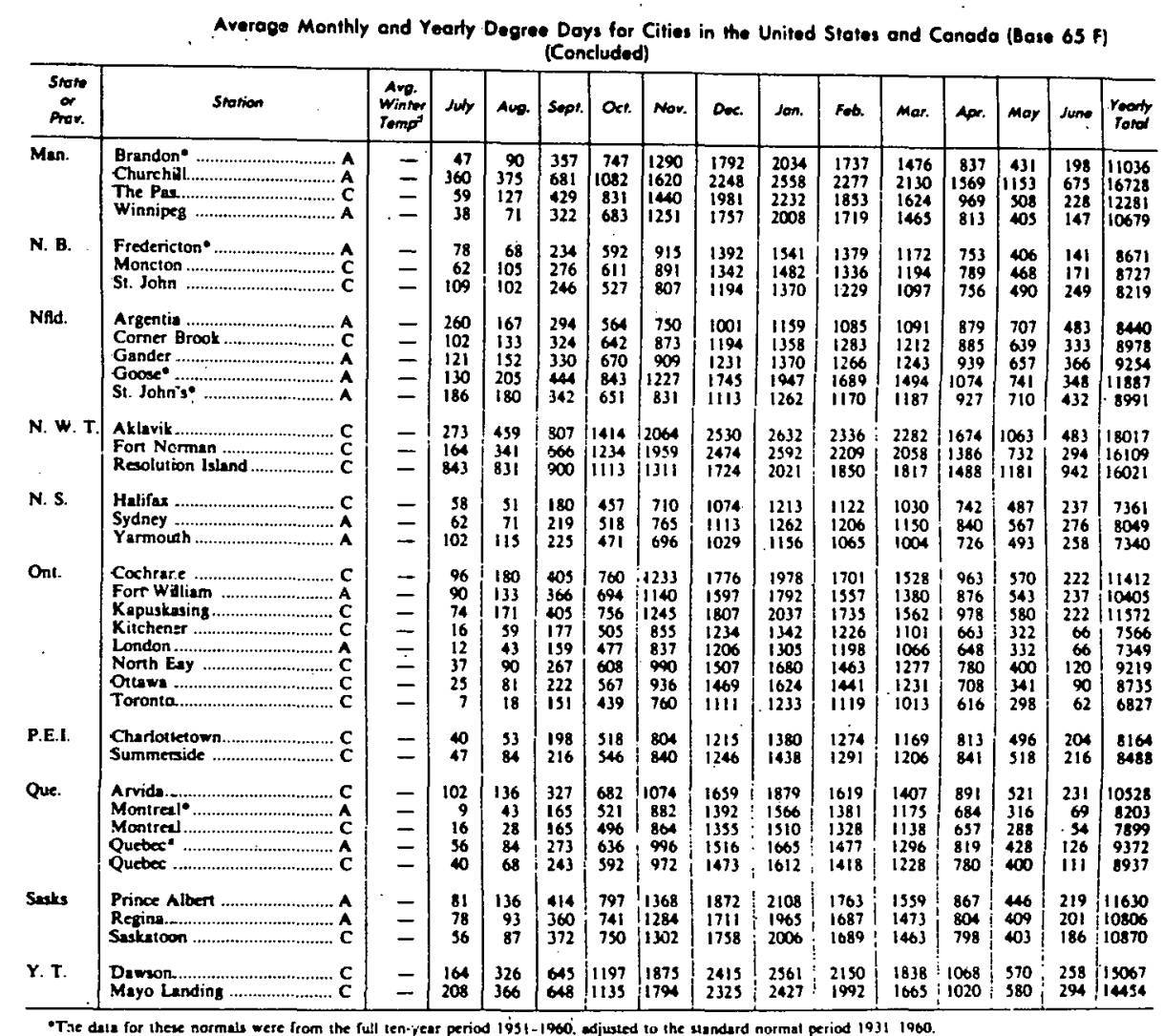


TABLES F \& G

Redietion and Othar Date for 80 Locatione in the United Statee

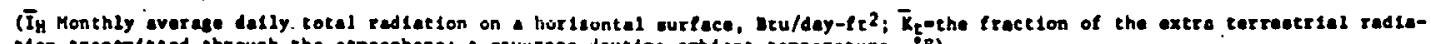

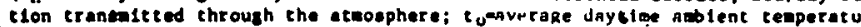

\begin{tabular}{|c|c|c|c|c|c|c|c|c|c|c|c|c|c|}
\hline ALASKA & & Jan & Feb & Mar & Apr & May & Jun & Jul & Aus & Sep & $\alpha<t$ & Hov' & Dec \\
\hline 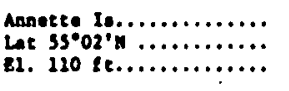 & $\begin{array}{l}\bar{I}_{n} \\
\bar{x}_{k} \\
t_{0}\end{array}$ & $\begin{array}{l}236.2 \\
0.427 \\
35.8\end{array}$ & $\begin{array}{l}428.4 \\
0.415 \\
37.5\end{array}$ & $\begin{array}{l}883.4 \\
0.492 \\
39.7\end{array}$ & $\begin{array}{l}1357.2 \\
0.507 \\
46.6\end{array}$ & $\begin{array}{l}1634.7 \\
0.484 \\
51.0\end{array}$ & $\begin{array}{l}1634.7 \\
0.441 \\
36.2\end{array}$ & $\begin{array}{l}1632.1 \\
0.454 \\
58.6\end{array}$ & $\begin{array}{l}1269.4 \\
0.427 \\
59.8\end{array}$ & $\begin{array}{l}962 \\
0.449 \\
34.8\end{array}$ & $\begin{array}{l}454.6 \\
0.347 \\
48.2\end{array}$ & $\begin{array}{l}220.3 \\
0.304 \\
41.9\end{array}$ & $\begin{array}{l}252 \\
0.361 \\
37.6\end{array}$ \\
\hline 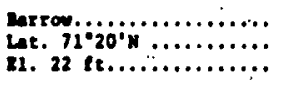 & $\begin{array}{l}\bar{I}_{h} \\
\bar{I}_{t} \\
t_{0}\end{array}$ & $\begin{array}{l}13.3 \\
-13.2\end{array}$ & $\begin{array}{l}143.2 \\
0.776 \\
-15.9\end{array}$ & $\begin{array}{l}713.3 \\
0.773 \\
-12.7\end{array}$ & $\begin{array}{l}1491.5 \\
0.726 \\
2.1\end{array}$ & $\begin{array}{l}1083 \\
0.553 \\
20.5\end{array}$ & $\begin{array}{l}2055.3 \\
0.533 \\
35.6\end{array}$ & $\begin{array}{l}1602.2 \\
0.448 \\
.11 .6\end{array}$ & $\begin{array}{l}933.3 \\
0.377 \\
60.0\end{array}$ & $\begin{array}{l}628.6 \\
0.315 \\
31.7\end{array}$ & $\begin{array}{l}152.6 \\
0.35 \\
18.6\end{array}$ & $\begin{array}{l}22.9 \\
2.6\end{array}$ & $\overline{-}$ \\
\hline 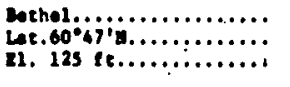 & $\begin{array}{l}\overline{\bar{\tau}_{t}} \\
\bar{z}_{t} \\
t_{0}\end{array}$ & $\begin{array}{l}142.4 \\
0.536 \\
9.2\end{array}$ & $\begin{array}{l}4048 \\
0.551 \\
11.6\end{array}$ & $\begin{array}{l}1052.4 \\
0.704 \\
14.2\end{array}$ & $\begin{array}{l}1662.3 \\
0.673^{3} \\
29.4\end{array}$ & $\begin{array}{l}1711.0 \\
0.519 \\
42.7\end{array}$ & $\begin{array}{l}1698.1 \\
0.458 \\
55.5\end{array}$ & $\begin{array}{l}1401.8 \\
0.398 \\
56.9\end{array}$ & $\begin{array}{l}938.7 \\
0.336 \\
34.8\end{array}$ & $\begin{array}{l}755 \\
0.406 \\
47.4\end{array}$ & $\begin{array}{l}630.6 \\
0.432 \\
33.7\end{array}$ & $\begin{array}{l}164.9 \\
0.399 \\
19.0\end{array}$ & $\begin{array}{l}83 \\
0.459 \\
9.4\end{array}$ \\
\hline 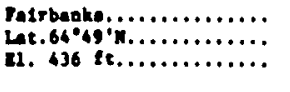 & $\begin{array}{l}\overline{\bar{I}_{\mathbf{H}}} \\
\overline{\mathbf{r}_{\mathbf{t}}} \\
\mathbf{t}_{0}\end{array}$ & $\begin{array}{l}66 \\
0.639 \\
-7.0\end{array}$ & $\begin{array}{l}283.4 \\
0.556 \\
0.3\end{array}$ & $\begin{array}{l}860.3 \\
0.674 \\
13.0\end{array}$ & $\begin{array}{l}1481.2 \\
0.647 \\
32.2\end{array}$ & $\begin{array}{l}1806.2 \\
0.546 \\
50.5\end{array}$ & $\begin{array}{l}1970.8 \\
0.329 \\
62.4\end{array}$ & $\begin{array}{l}1702.9 \\
0.485 \\
63.8\end{array}$ & $\begin{array}{l}1247.6 \\
0.463 \\
38.3\end{array}$ & $\begin{array}{l}699.6 \\
0.419 \\
47.1\end{array}$ & $\begin{array}{l}323.6 \\
0.416 \\
29.6\end{array}$ & $\begin{array}{l}104.1 \\
0.67 \\
3.5\end{array}$ & $\begin{array}{l}20.3 \\
0.458 \\
-6.6\end{array}$ \\
\hline 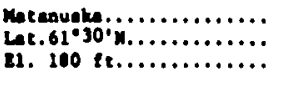 & $\begin{array}{l}\bar{I}_{H_{H}} \\
\bar{R}_{t} \\
t_{0}\end{array}$ & $\begin{array}{l}119.2 \\
0.513 \\
13.9\end{array}$ & $\begin{array}{l}345 \\
0.503 \\
21.0\end{array}$ & $\begin{array}{c}- \\
27.4\end{array}$ & $\begin{array}{l}1327.6 \\
0.565^{\circ} \\
38.6\end{array}$ & $\begin{array}{l}1628.4 \\
0.496 \\
50.3\end{array}$ & $\begin{array}{l}1727.6 \\
0.466 \\
37.6\end{array}$ & $\begin{array}{l}1526.9 \\
0.434 \\
60.1\end{array}$ & $\begin{array}{l}1169 \\
0.619 \\
38.1\end{array}$ & $\begin{array}{l}737.3 \\
0.401 \\
50.2\end{array}$ & $\begin{array}{l}373.8 \\
0.390 \\
37.7\end{array}$ & $\begin{array}{l}142.8 \\
0.372 \\
22.9\end{array}$ & $\begin{array}{l}56.4 \\
0.36 \prime \\
13.9\end{array}$ \\
\hline \multicolumn{14}{|l|}{ ALBERTA } \\
\hline 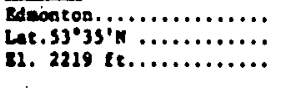 & $\begin{array}{l}\bar{I}_{H_{H}} \\
\bar{k}_{t} \\
\mathbf{E}_{0}\end{array}$ & $\begin{array}{l}331.7 \\
0.329 \\
10.6\end{array}$ & $\begin{array}{l}652.4 \\
0.585 \\
16\end{array}$ & $\begin{array}{l}1165.3 \\
0.624 \\
26.3\end{array}$ & $\begin{array}{l}1941.7 \\
0.564 \\
42.9\end{array}$ & $\begin{array}{l}1900.4 \\
0.558 \\
55.4\end{array}$ & $\begin{array}{l}1914.4 \\
0.514 . \\
61.3 .\end{array}$ & $\begin{array}{l}1964.9 \\
0.569 \\
66.6\end{array}$ & $\begin{array}{l}1528 \\
0.506 \\
63.2\end{array}$ & $\begin{array}{l}1113.3 \\
0.506 \\
54.2\end{array}$ & $\begin{array}{l}104.4 \\
0.506 \\
44.1\end{array}$ & $\begin{array}{l}413.6 \\
0.310 \\
26.7\end{array}$ & $\begin{array}{l}245 \\
0.492 \\
14.0\end{array}$ \\
\hline \multicolumn{14}{|l|}{ Amunsas } \\
\hline $\begin{array}{l}\text { Lite 10 Rock } \\
\text { Let.34*4h'1" } \\
\text { BI. } 265 \text { tt. }\end{array}$ & $\begin{array}{l}\overline{\bar{I}_{y}} \\
\bar{x}_{\mathbf{t}} \\
t_{0}\end{array}$ & $\begin{array}{l}704.4 \\
0.424 \\
44.6\end{array}$ & $\begin{array}{l}974.2 \\
0.658 \\
48.5\end{array}$ & $\begin{array}{l}1335.8 \\
0.496 \\
56.0\end{array}$ & $\begin{array}{l}1669.4 \\
0.513 \\
65.8\end{array}$ & $\begin{array}{l}1960.1 \\
0.543 \\
73.1\end{array}$ & $\begin{array}{l}2091.5 \\
0.559 \\
76.7\end{array}$ & $\begin{array}{l}2081.2 \\
0.566 \\
85.1\end{array}$ & $\begin{array}{l}1938.7 \\
0.576 \\
84.6\end{array}$ & $\begin{array}{l}1640.6 \\
0.561 \\
78.3\end{array}$ & $\begin{array}{l}1282.6 \\
0.552 \\
67.9\end{array}$ & $\begin{array}{l}913.6 \\
0.484 \\
34.7\end{array}$ & $\begin{array}{l}701.2 \\
0.463 \\
46.7\end{array}$ \\
\hline \multicolumn{14}{|l|}{ ARizoNa } \\
\hline 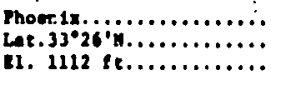 & $\begin{array}{l}\bar{I}_{H} \\
\bar{x}_{t} \\
t_{0}\end{array}$ & $\begin{array}{l}1126.6 \\
0.65 \\
94.2\end{array}$ & $\begin{array}{l}1516.7 \\
0.691 \\
38.8\end{array}$ & $\begin{array}{l}1967.1 \\
0.716 \\
64.7\end{array}$ & $\begin{array}{l}2388.2 \\
0.728 \\
72.2\end{array}$ & $\begin{array}{l}2709.6 \\
0.753 \\
80.8\end{array}$ & $\begin{array}{l}2781.5 \\
0.745 \\
09.2\end{array}$ & $\begin{array}{l}2450.5 \\
0.667 . \\
94.6\end{array}$ & $\begin{array}{l}2299.6 \\
0.677^{\circ} \\
92.5\end{array}$ & $\begin{array}{l}2131.3 \\
8722 \\
87.4\end{array}$ & & $\begin{array}{l}1290 \\
0.657 \\
63.6\end{array}$ & $\begin{array}{l}1040.9 \\
0.652 \\
36.7\end{array}$ \\
\hline 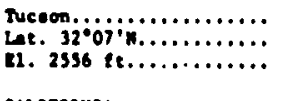 & $\begin{array}{l}\bar{z}_{H} \\
\bar{x}_{t} \\
c_{0}\end{array}$ & $\begin{array}{l}1171.9 \\
0.648 \\
33.7\end{array}$ & $\begin{array}{l}1453.8 \\
0.646 \\
37.3\end{array}$ & 62.3 & $\begin{array}{l}2634.7 \\
0.738 \\
69.7\end{array}$ & 78.0 & $\begin{array}{l}2601.4 \\
0698 \\
87.0\end{array}$ & $\begin{array}{l}2292.2 \\
0.625 \\
90.1\end{array}$ & $\begin{array}{l}2179.7 \\
0.640 \\
87.4\end{array}$ & & & $\begin{array}{l}1322.1 \\
0.650 \\
62.5\end{array}$ & $\begin{array}{l}1132.1 \\
0.679 \\
36.1\end{array}$ \\
\hline \multicolumn{14}{|l|}{ CALIFORNIA } \\
\hline 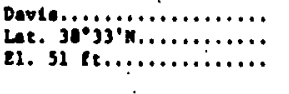 & $\begin{array}{l}\bar{I}_{H_{H}} \\
\bar{R}_{t} \\
t_{0}\end{array}$ & $\begin{array}{l}399.2 \\
0.416 \\
47.6\end{array}$ & $\begin{array}{l}943 \\
0.490 \\
52.1\end{array}$ & $\begin{array}{l}15114 \\
0.591 \\
56.8\end{array}$ & $\begin{array}{l}1959 \\
0.617 \\
63.1\end{array}$ & $\begin{array}{l}2368.6 \\
0.662 \\
69.6\end{array}$ & $\begin{array}{l}2619.2 \\
0.697 \\
75.7\end{array}$ & $\begin{array}{l}2565.6 \\
0.697 \\
81\end{array}$ & $\begin{array}{l}2207.8 \\
0.687^{\circ} \\
79.4\end{array}$ & $\begin{array}{l}1856.8 \\
0.664 \\
76.7\end{array}$ & $\begin{array}{l}1235.5 \\
0.598 \\
67.8\end{array}$ & $\begin{array}{l}795.6 \\
0.677 \\
5 ?\end{array}$ & $\begin{array}{l}550.5 \\
0.421 \\
48.7\end{array}$ \\
\hline 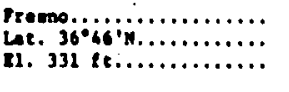 & $\begin{array}{l}\bar{I}_{H_{1}} \\
x_{t_{t}} \\
r_{0}\end{array}$ & $\begin{array}{l}712.9 \\
0.462 \\
67.3\end{array}$ & $\begin{array}{l}1116.6 \\
0.551 \\
33.9\end{array}$ & $\begin{array}{l}1632.8 \\
0.632 \\
59.1\end{array}$ & $\begin{array}{l}2049.6 \\
0.638^{6} \\
65.6\end{array}$ & $\begin{array}{l}2609.2 \\
0.677^{2} \\
73.3\end{array}$ & $\begin{array}{l}2641.7 \\
0.703^{2} \\
80.7\end{array}$ & $\begin{array}{l}2512.2 \\
0.682 \\
87.5\end{array}$ & $\begin{array}{l}2300.7 \\
0.686 \\
04.9\end{array}$ & & $\begin{array}{l}1615.5 \\
0.635 \\
68.7\end{array}$ & $\begin{array}{l}906.6 \\
0.512 \\
57.3\end{array}$ & $\begin{array}{l}616.6 \\
0.44 \\
40.9\end{array}$ \\
\hline 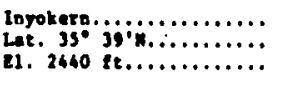 & $\begin{array}{l}\overline{\mathbf{Z}}_{\mathbf{H}} \\
\overline{\mathbf{k}}_{\mathbf{t}} \\
\varepsilon_{0}\end{array}$ & $\begin{array}{l}1148.7 \\
0.716 \\
47.3\end{array}$ & $\begin{array}{l}1554.2 \\
0.745 \\
53.9\end{array}$ & $\begin{array}{l}2136.9 \\
0.803 \\
59.1\end{array}$ & $\begin{array}{l}2596.8 \\
0.8 \\
65.6\end{array}$ & $\begin{array}{l}2925.4 \\
0.815 \\
73.5\end{array}$ & $\begin{array}{l}3108.8 \\
0.830 \\
80.7\end{array}$ & $\begin{array}{l}2908.8 \\
0.790 \\
87.5\end{array}$ & & & & $\begin{array}{l}3170.1 \\
0.763 \\
57.3\end{array}$ & \\
\hline 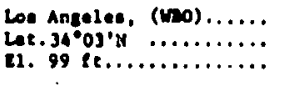 & $\begin{array}{l}\bar{I}_{H} \\
\bar{K}_{\mathbf{t}} \\
t_{n} \\
-\end{array}$ & $\begin{array}{l}911.8 \\
0.338 \\
57.9\end{array}$ & $\begin{array}{l}1223.6 \\
0.368 \\
59.2\end{array}$ & $\begin{array}{l}1640.9 \\
0.602 \\
61.8\end{array}$ & $\begin{array}{l}1866.8 \\
0.571 \\
64.3\end{array}$ & $\begin{array}{l}2061.2 \\
0.573 \\
67.6\end{array}$ & $\begin{array}{l}2259 \\
0.605 \\
70.7\end{array}$ & $\begin{array}{l}24284 \\
0.66 \\
75.8\end{array}$ & $\begin{array}{l}2198.9 \\
0.648^{\circ} \\
76.1\end{array}$ & $\begin{array}{l}1891.5 \\
0.643 \\
74.2\end{array}$ & $\begin{array}{l}1362.3 \\
0.570^{3} \\
69.6\end{array}$ & $\begin{array}{l}1053.1 \\
0.568 \\
65.4\end{array}$ & $\begin{array}{l}811.8 \\
0.566 \\
60.2\end{array}$ \\
\hline 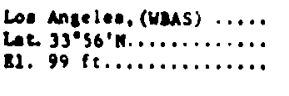 & $\begin{array}{l}\bar{I}_{\eta} \\
\bar{k}_{k} \\
t_{0}\end{array}$ & $\begin{array}{l}930.6 \\
0.347 \\
36.2\end{array}$ & $\begin{array}{l}1284.1 \\
0.596 \\
36.9\end{array}$ & $\begin{array}{l}1729.5 \\
0.635 \\
39.2\end{array}$ & $\begin{array}{l}948 \\
1.595 \\
1.4\end{array}$ & $\begin{array}{l}2196.7 \\
0.610 \\
66.2\end{array}$ & $\begin{array}{l}2272.3 \\
0.608 \\
66.7\end{array}$ & $\begin{array}{l}2413.6 \\
0.657 \\
69.6\end{array}$ & $\begin{array}{l}2153.3 \\
0.635 \\
70.2\end{array}$ & & $\begin{array}{l}1372.7 \\
0.576 \\
66.1\end{array}$ & $\begin{array}{l}1082.3 \\
0.351 \\
62.6\end{array}$ & \\
\hline 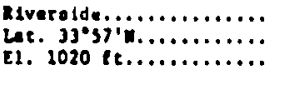 & $\begin{array}{l}\overline{\mathbf{I}}_{\mathrm{H}} \\
\overline{\mathbf{R}}_{\mathrm{r}} \\
t_{0}\end{array}$ & $\begin{array}{l}999.6 \\
0.589 \\
55.3\end{array}$ & $\begin{array}{l}1333 \\
0.617 \\
37.0\end{array}$ & $\begin{array}{l}1750.5 \\
0.643 \\
60.6\end{array}$ & $\begin{array}{l}943.2 \\
594 \\
5.0\end{array}$ & $\begin{array}{l}2282.3 \\
0.635 \\
69.4\end{array}$ & $\begin{array}{l}2492.6 \\
0.667 \\
74.0\end{array}$ & $\begin{array}{l}2443.5 \\
0.665 \\
81.0\end{array}$ & $\begin{array}{l}2263.8 \\
0.668 \\
81.0\end{array}$ & & $\begin{array}{l}1509.6 \\
0.639^{\circ} \\
71.0\end{array}$ & $\begin{array}{l}1169 \\
0.606 \\
63.1\end{array}$ & \\
\hline 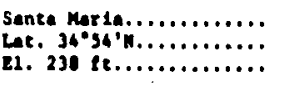 & $\begin{array}{l}\bar{I}_{I_{t}} \\
t_{t} \\
t_{0}\end{array}$ & $\begin{array}{l}993.8 \\
0.593 \\
54.1\end{array}$ & $\begin{array}{l}1296.3 \\
0.613^{3} \\
55.3\end{array}$ & $\begin{array}{l}1805.9 \\
0.671^{3} \\
37.6\end{array}$ & $\begin{array}{l}2067.9 \\
0.636 \\
59.5\end{array}$ & $\begin{array}{l}2375.6 \\
0.661 \\
61.2\end{array}$ & $\begin{array}{l}2599.6 \\
0.695 \\
63.5\end{array}$ & $\begin{array}{l}2540.6 \\
0.690 \\
65.3\end{array}$ & $\begin{array}{l}2293.3 \\
0.678 \\
69.7\end{array}$ & $\begin{array}{l}1965.7 \\
0.674 \\
65.9\end{array}$ & $\begin{array}{l}1566.6 \\
0.676 \\
66.1\end{array}$ & $\begin{array}{l}1169 \\
0.624 \\
60.8\end{array}$ & $\begin{array}{l}963.9 \\
0.627 \\
56.1\end{array}$ \\
\hline \multicolumn{14}{|l|}{ COLORADO } \\
\hline 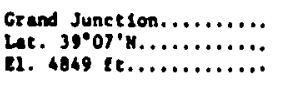 & $\begin{array}{l}\bar{I}_{M} \\
\bar{x}_{2} \\
t_{0}\end{array}$ & $\begin{array}{l}048 \\
0.597 \\
26.9\end{array}$ & $\begin{array}{l}1210.7 \\
0.633^{3} \\
35.0\end{array}$ & $\begin{array}{l}1622.9 \\
0.663 \\
44.6\end{array}$ & $\begin{array}{l}2002.2 \\
0.632 \\
55.8\end{array}$ & $\begin{array}{l}2300.3 \\
0.663 \\
66.3\end{array}$ & $\begin{array}{l}2645.4 \\
0.704 \\
75.7\end{array}$ & $\begin{array}{l}2517.7 \\
0.690 \\
82.5\end{array}$ & $\begin{array}{l}2157.2 \\
0.65 \\
79.6\end{array}$ & & $\begin{array}{l}1394.8 \\
0.654 \\
58.3\end{array}$ & $\begin{array}{l}969.7 \\
0.59 \\
42.0\end{array}$ & $\begin{array}{l}793.4 \\
0.621 \\
31.6\end{array}$ \\
\hline 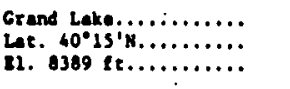 & $\begin{array}{l}\overline{\bar{I}_{H}} \\
\bar{x}_{t} \\
t_{0}\end{array}$ & $\begin{array}{l}735 \\
0.541 \\
18.5\end{array}$ & $\begin{array}{l}1135.4 \\
0.615 \\
23.1\end{array}$ & $\begin{array}{l}1579.3 \\
0.637 \\
28.5\end{array}$ & $\begin{array}{l}1876.7 \\
0.597 \\
39.1\end{array}$ & $\begin{array}{l}1974.9 \\
0.533 \\
48.7\end{array}$ & $\begin{array}{l}2369.7 \\
0.63 \\
56.6\end{array}$ & $\begin{array}{l}2103.3 \\
0.572 \\
62.8\end{array}$ & $\begin{array}{l}1708.5 \\
0.516 \\
61.5\end{array}$ & $\begin{array}{l}1715.8 \\
0.626 \\
55.9\end{array}$ & $\begin{array}{l}1212.2 \\
0.583 \\
45.2\end{array}$ & $\begin{array}{l}775.6 \\
0.494 \\
30.3\end{array}$ & $\begin{array}{l}660.5 \\
0.542 \\
22.6\end{array}$ \\
\hline
\end{tabular}




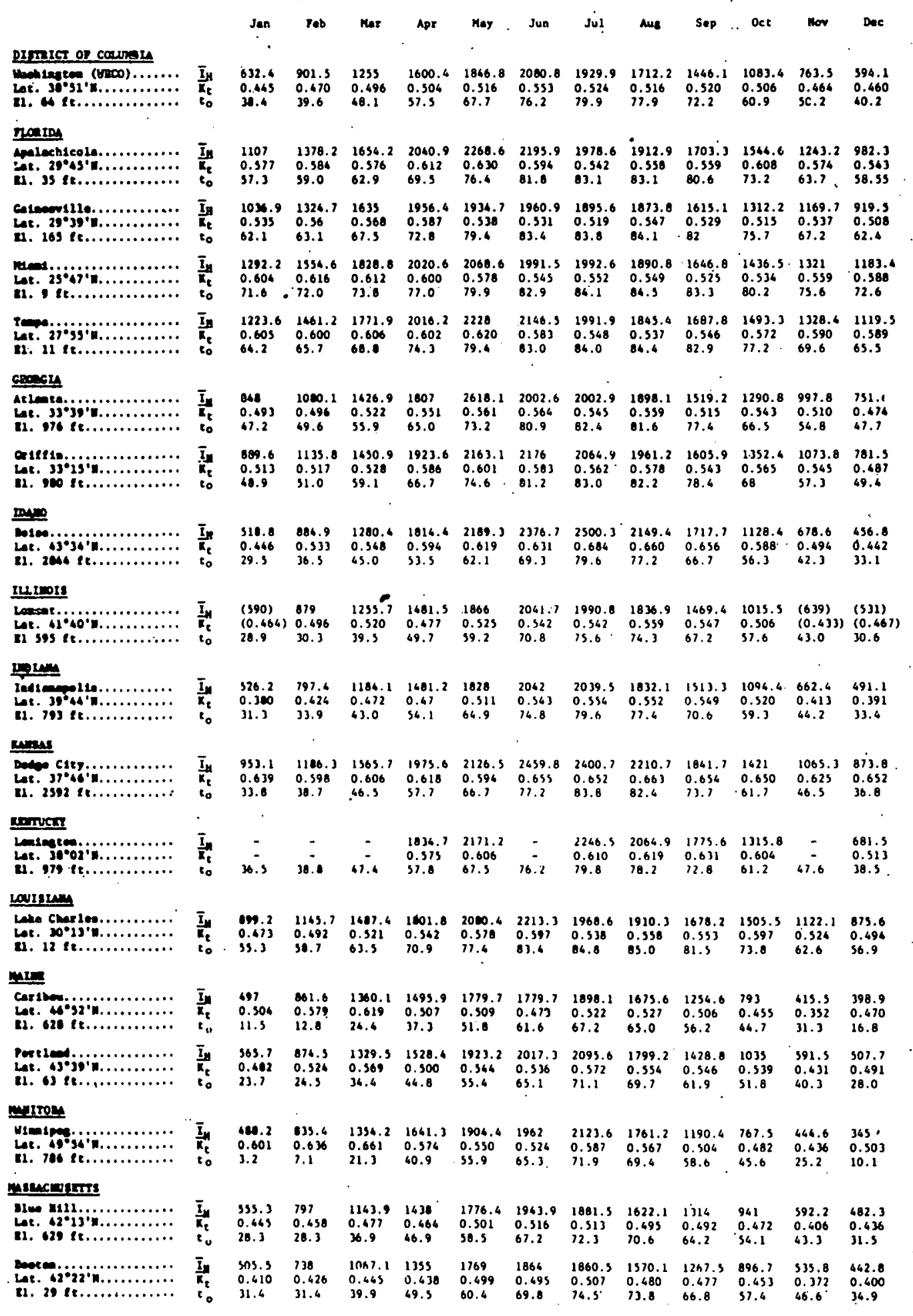




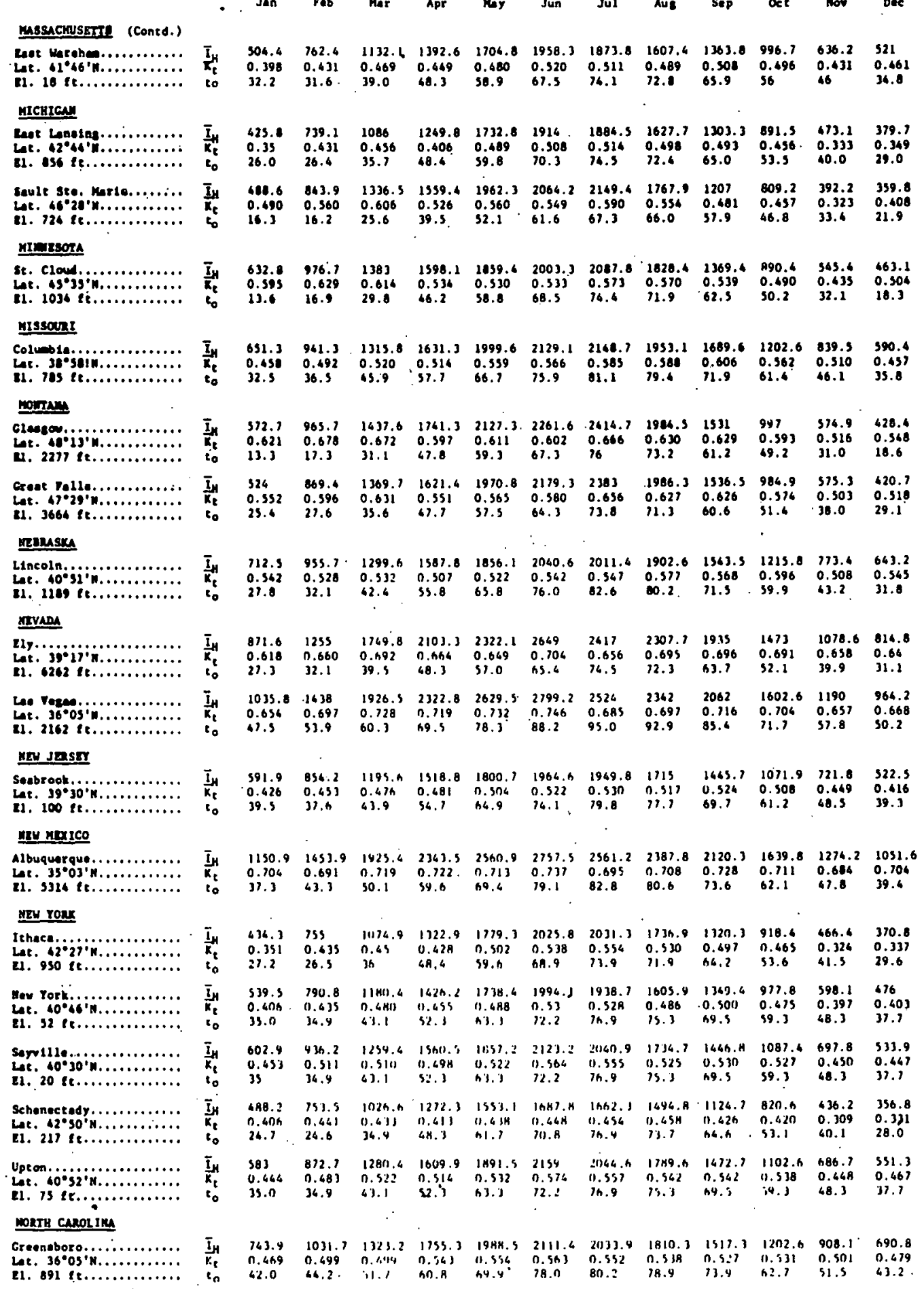




\begin{tabular}{|c|c|c|c|c|c|c|c|c|c|c|c|c|c|}
\hline 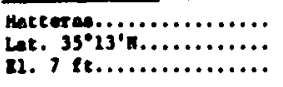 & $\begin{array}{l}\overline{I_{1}} \\
\bar{x}_{t} \\
t_{0}\end{array}$ & $\begin{array}{l}891.9 \\
0.546 \\
69.9\end{array}$ & $\begin{array}{l}1184.1 \\
0.363 \\
49.5\end{array}$ & $\begin{array}{l}1390.4 \\
0.593 \\
54.7\end{array}$ & $\begin{array}{l}2128 \\
0.653 \\
61.5\end{array}$ & $\begin{array}{l}2376.4 \\
0.661 \\
69.9\end{array}$ & $\begin{array}{l}2438 \\
0.652 \\
77.2\end{array}$ & $\begin{array}{l}2334.3 \\
0.636 \\
80.0\end{array}$ & $\begin{array}{l}2083.6 \\
0.619 \\
79.8\end{array}$ & $\begin{array}{l}1758.3 \\
0.605 \\
76.7\end{array}$ & $\begin{array}{l}1337.6 \\
0.38 \\
67.9\end{array}$ & $\begin{array}{l}1053.5 \\
0.566 \\
59.1\end{array}$ & $\begin{array}{l}798.1 \\
0.535 \\
51.3\end{array}$ \\
\hline \multicolumn{14}{|l|}{ DonTe purota } \\
\hline $\begin{array}{l}\text { s1merck.j..... } \\
\text { Let. } 460 \% \text { in.. } \\
\text { s1. } 1660 \text { et... }\end{array}$ & $\begin{array}{l}\bar{I}_{M} \\
\bar{T}_{\mathbf{H}} \\
i_{0}\end{array}$ & $\begin{array}{l}387.6 \\
0.394 \\
12.4\end{array}$ & $\begin{array}{l}136.3 \\
0.620 \\
13.9\end{array}$ & $\begin{array}{l}1328.4 \\
0.605 \\
29.7\end{array}$ & $\begin{array}{l}1660.2 \\
0.565 \\
66.6\end{array}$ & $\begin{array}{l}2056.1 \\
0.580 \\
58.6\end{array}$ & $\begin{array}{l}2173.8 \\
0.579 \\
67.9\end{array}$ & $\begin{array}{l}2305.5 \\
0.634 \\
76.1\end{array}$ & $\begin{array}{l}1929.1 \\
0.606 \\
73.5\end{array}$ & $\begin{array}{l}1461.3 \\
0.581 \\
61.6\end{array}$ & $\begin{array}{l}1018.1 \\
0.584 \\
69.6\end{array}$ & $\begin{array}{l}600.6 \\
0.510 \\
31.6\end{array}$ & $\begin{array}{l}464.2 \\
0.547 \\
18.4\end{array}$ \\
\hline 오ro & & & $\cdot$ & & & - & & & & & & & \\
\hline 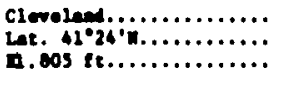 & $\begin{array}{l}Y_{1} \\
x_{t} \\
t_{0}\end{array}$ & $\begin{array}{l}666.8 \\
0.361 \\
30.0\end{array}$ & $\begin{array}{l}602.9 \\
0.303 \\
30.9\end{array}$ & $\begin{array}{l}1207 \\
0.497 \\
39.4\end{array}$ & $\begin{array}{l}1643.9 \\
0.464 \\
30.2\end{array}$ & $\begin{array}{l}1928.4 \\
0.543 \\
62.4\end{array}$ & $\begin{array}{l}2102.6 \\
0.559 \\
72.7\end{array}$ & $\begin{array}{l}2094.4 \\
0.571 \\
17.0\end{array}$ & $\begin{array}{l}1840.6 \\
0.559 \\
75.1\end{array}$ & $\begin{array}{l}1410.3 \\
0.524 \\
68.5\end{array}$ & $\begin{array}{l}997 \\
0.491 \\
57.4\end{array}$ & $\begin{array}{l}326.6 \\
0.351 \\
44.0\end{array}$ & $\begin{array}{l}427.3 \\
0.371 \\
32.8\end{array}$ \\
\hline 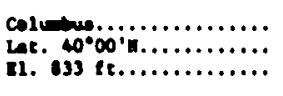 & $\begin{array}{l}\bar{I}_{\mathbf{n}} \\
\mathbf{k}_{\mathrm{t}} \\
\mathbf{E}_{0}\end{array}$ & $\begin{array}{l}486.3 \\
0.336 \\
32.1\end{array}$ & $\begin{array}{l}746.5 \\
0.401 \\
33.7\end{array}$ & $\begin{array}{l}1112.5 \\
0.447 \\
62.7\end{array}$ & $\begin{array}{l}1680.8 \\
0.470 \\
53.5\end{array}$ & $\begin{array}{l}1839.1 \\
0.515 \\
66.4\end{array}$ & $\begin{array}{l}(2111) \\
(0.561) \\
74.2\end{array}$ & $\begin{array}{l}2041.3 \\
0.555 \\
78\end{array}$ & $\begin{array}{l}1572.7 \\
0.475 \\
75.9\end{array}$ & $\begin{array}{l}1189.3 \\
0.433 \\
70.1\end{array}$ & $\begin{array}{l}919.5 \\
0.461 \\
58\end{array}$ & $\begin{array}{l}479 \\
0.302 \\
44.5\end{array}$ & $\begin{array}{l}430.2 \\
0.351 \\
34.0\end{array}$ \\
\hline adanon & & & & & & & & & & & & & \\
\hline 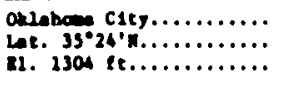 & $\begin{array}{l}\bar{I}_{\mathbf{r}} \\
\mathbf{x}_{t} \\
t_{0}\end{array}$ & $\begin{array}{l}938 \\
0.580 \\
40.1\end{array}$ & $\begin{array}{l}1192.6 \\
0.571 \\
43.0\end{array}$ & $\begin{array}{l}1534.3 \\
0.576 \\
33.2\end{array}$ & $\begin{array}{l}1849.4 \\
0.570 \\
63.6\end{array}$ & $\begin{array}{l}2005.1 \\
0.598 \\
71.2\end{array}$ & $\begin{array}{l}2355 \\
0.629 \\
80.6\end{array}$ & $\begin{array}{l}2273.8 \\
0.618 \\
85.5\end{array}$ & $\begin{array}{l}2211 \\
0.565 \\
85.4\end{array}$ & $\begin{array}{l}1819.2 \\
0.628 \\
77.4\end{array}$ & $\begin{array}{l}1409.6 \\
0.616 \\
66.5\end{array}$ & $\begin{array}{l}1085.6 \\
0.588 \\
52.2\end{array}$ & $\begin{array}{l}897.6 \\
0.600 \\
63.1\end{array}$ \\
\hline 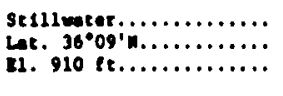 & $\begin{array}{l}\overline{\mathbf{t}_{y}} \\
\bar{x}_{t} \\
\varepsilon_{0}\end{array}$ & $\begin{array}{l}763.8 \\
0.484 \\
41.2\end{array}$ & $\begin{array}{l}1081.5 \\
0.527 \\
49.6\end{array}$ & $\begin{array}{l}1463.8 \\
0.535 \\
53.8\end{array}$ & $\begin{array}{l}1702.6 \\
0.328 \\
64.2\end{array}$ & $\begin{array}{l}1879.3 \\
0.523 \\
71.6\end{array}$ & $\begin{array}{l}2235.8 \\
0.596 \\
81.1\end{array}$ & $\begin{array}{l}2224.3 \\
0.604 \\
85.9\end{array}$ & $\begin{array}{l}2039.1 \\
0.607 \\
85.9\end{array}$ & $\begin{array}{l}1724.3 \\
0.599 \\
77.5\end{array}$ & $\begin{array}{l}1316 \\
0.581 \\
67.6\end{array}$ & $\begin{array}{l}991.5 \\
0.548 \\
52.6\end{array}$ & $\begin{array}{l}783 \\
0.546 \\
43.9\end{array}$ \\
\hline \multicolumn{14}{|l|}{ onranio } \\
\hline 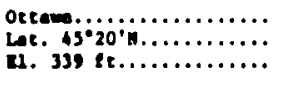 & $\begin{array}{l}\overline{\mathbf{I}}_{\mathrm{H}} \\
\mathrm{R}_{\mathrm{c}} \\
\mathrm{r}_{\mathrm{O}}\end{array}$ & $\begin{array}{l}539.1 \\
0.699 \\
14.6\end{array}$ & $\begin{array}{l}852.4 \\
0.560 \\
15.6\end{array}$ & $\begin{array}{l}1250.5 \\
0.536 \\
27.7\end{array}$ & $\begin{array}{l}1506.6 \\
0.502 \\
43.3\end{array}$ & $\begin{array}{l}2857.2 \\
0.529 \\
57.5\end{array}$ & $\begin{array}{l}2084.5 \\
0.554 \\
67.5\end{array}$ & $\begin{array}{l}2045.4 \\
0.560 \\
71.9\end{array}$ & $\begin{array}{l}1752.4 \\
0.546 \\
69.8\end{array}$ & $\begin{array}{l}1326.6 \\
0.321 \\
61.5\end{array}$ & $\begin{array}{l}826.9 \\
0.450 \\
48.9\end{array}$ & $\begin{array}{l}458.7 \\
0.359 \\
35\end{array}$ & $\begin{array}{l}408.5 \\
0.636 \\
19.6\end{array}$ \\
\hline 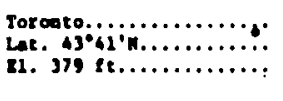 & $\begin{array}{l}\overline{\mathbf{I}_{H}} \\
\overline{\mathbf{x}_{t}} \\
\mathbf{t}_{0}\end{array}$ & $\begin{array}{l}451.3 \\
0.388 \\
26.5\end{array}$ & $\begin{array}{l}074.5 \\
0.406 \\
26.0\end{array}$ & $\begin{array}{l}1088.9 \\
0.467 \\
34.2\end{array}$ & $\begin{array}{l}1388.2 \\
0.455 \\
46.3\end{array}$ & $\begin{array}{l}1785.2 \\
0.306 \\
58\end{array}$ & $\begin{array}{l}1961.7 \\
0.516 \\
68.4\end{array}$ & $\begin{array}{l}1968.6 \\
0.539 \\
73.8\end{array}$ & $\begin{array}{l}1622.9 \\
0.500 \\
71.8\end{array}$ & $\begin{array}{l}1284.1 \\
0.493 \\
64.3\end{array}$ & $\begin{array}{l}835 \\
0.438 \\
52.6\end{array}$ & $\begin{array}{l}458.3 \\
0.336 \\
40.9\end{array}$ & $\begin{array}{l}352.8 \\
0.346 \\
30.2\end{array}$ \\
\hline \multicolumn{14}{|l|}{ ancon } \\
\hline 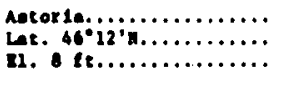 & $\begin{array}{l}T_{n} \\
x_{t} \\
t_{0}\end{array}$ & $\begin{array}{l}338.4 \\
0.330 \\
61.3\end{array}$ & $\begin{array}{l}607 \\
0.397 \\
44.7\end{array}$ & $\begin{array}{l}1008.3 \\
0.454 \\
46.9\end{array}$ & $\begin{array}{l}1001.5 \\
0.471 \\
31.3\end{array}$ & $\begin{array}{l}1838.7 \\
0.524 \\
35.0\end{array}$ & $\begin{array}{l}1733.9 \\
0.466 \\
59.3\end{array}$ & $\begin{array}{l}2007.7 \\
0.551 \\
62.6\end{array}$ & $\begin{array}{l}1721 \\
0.538 \\
63.6\end{array}$ & $\begin{array}{l}1322.3 \\
0.526 \\
62.2\end{array}$ & $\begin{array}{l}780.4 \\
0.435 \\
35.7\end{array}$ & $\begin{array}{l}413.6 \\
0.336 \\
48.5\end{array}$ & $\begin{array}{l}299.2 \\
0.332 \\
43.9\end{array}$ \\
\hline $\begin{array}{l}\text { Rede ord } \ldots \ldots \ldots \ldots \ldots \ldots \\
\text { Lat. } 42^{\circ} 23^{\prime} \ldots \ldots \ldots \ldots \ldots \ldots\end{array}$ & $\begin{array}{l}\overline{I_{y}} \\
\bar{x}_{2} \\
t_{0}\end{array}$ & $\begin{array}{l}635.4 \\
0.353 \\
39.4\end{array}$ & $\begin{array}{l}804.4 \\
0.464 \\
45.4\end{array}$ & $\begin{array}{l}1259.8 \\
0.527 \\
30.8\end{array}$ & $\begin{array}{l}1807.4 \\
0.584 \\
36.3\end{array}$ & $\begin{array}{l}2216.2 \\
0.625 \\
63.1\end{array}$ & $\begin{array}{l}2440.5 \\
0.648 \\
69.4\end{array}$ & $\begin{array}{l}2607.4 \\
0.710 \\
76.9\end{array}$ & $\begin{array}{l}2261.6 \\
0.689 \\
76.4\end{array}$ & $\begin{array}{l}1672.3 \\
0.628 \\
69.6\end{array}$ & $\begin{array}{l}1043.5 \\
0.526 \\
38.7\end{array}$ & $\begin{array}{l}558.7 \\
0.386 \\
47.1\end{array}$ & $\begin{array}{l}346.5 \\
0.313 \\
40.5\end{array}$ \\
\hline Punstryaria & & & & & & & & , & & & & & \\
\hline 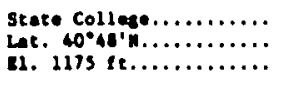 & $\begin{array}{l}\overline{\bar{I}_{H}} \\
\bar{x}_{t} \\
t_{0}\end{array}$ & $\begin{array}{l}501.8 \\
0.381 \\
31.3\end{array}$ & $\begin{array}{l}749.1 \\
0.413 \\
31.4\end{array}$ & $\begin{array}{l}1106.6 \\
0.451 \\
39.8\end{array}$ & $\begin{array}{l}1399.2 \\
0.448 \\
51.3\end{array}$ & $\begin{array}{l}1754.6 \\
0.493 \\
63.4\end{array}$ & $\begin{array}{l}2027.6 \\
0.539 \\
71.8\end{array}$ & $\begin{array}{l}1968.2 \\
0.536 \\
75.8\end{array}$ & $\begin{array}{l}1690 \\
0.512 \\
73.4\end{array}$ & $\begin{array}{l}1336.1 \\
0.492 \\
66.1\end{array}$ & $\begin{array}{l}1017 \\
0.496 \\
55.6\end{array}$ & $\begin{array}{l}580.1 \\
0.379 \\
43.2\end{array}$ & $\begin{array}{l}0.63 .9 \\
0.316 \\
32.6\end{array}$ \\
\hline \multicolumn{14}{|l|}{ I01010 } \\
\hline 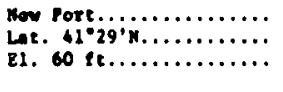 & $\begin{array}{c}\overline{\mathbf{I}}_{\mathbf{H}} \\
\overline{\mathbf{X}}_{\mathbf{l}} \\
t_{0}\end{array}$ & $\begin{array}{l}565.7 \\
0.438 \\
29.5\end{array}$ & $\begin{array}{l}856.4 \\
0.482 \\
32.0\end{array}$ & $\begin{array}{l}1231.7 \\
0.507^{2} \\
39.6\end{array}$ & $\begin{array}{l}1404.8 \\
0.477 \\
48.2\end{array}$ & $\begin{array}{l}1849 \\
0.520 \\
58.6\end{array}$ & $\begin{array}{l}2019.2 \\
0.536 \\
67.0\end{array}$ & $\begin{array}{l}1942.8 \\
0.329 \\
73.2\end{array}$ & $\begin{array}{l}1687.1 \\
0.513 \\
12.3\end{array}$ & $\begin{array}{l}1411.4 \\
0.324 \\
66.7\end{array}$ & $\begin{array}{l}1035.6 \\
0.512 \\
56.2\end{array}$ & $\begin{array}{l}656.1 \\
0.44 \\
46.5\end{array}$ & $\begin{array}{l}527.7 \\
0.460 \\
34.4\end{array}$ \\
\hline \multicolumn{14}{|l|}{ SOUTH CMOLINA } \\
\hline 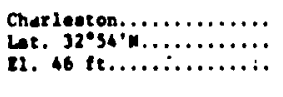 & $\begin{array}{l}\bar{z}_{k} \\
x_{t} \\
c_{0}\end{array}$ & $\begin{array}{l}946.1 \\
0.541 \\
33.6\end{array}$ & $\begin{array}{l}1152.8 \\
0.321 \\
53.2\end{array}$ & $\begin{array}{l}1352.4 \\
0.491 \\
60.6\end{array}$ & $\begin{array}{l}1918.8 \\
0.584 \\
67.8\end{array}$ & $\begin{array}{l}2063.4 \\
0.574 \\
74.8\end{array}$ & $\begin{array}{l}2113.3 \\
0.567^{3} \\
80.9\end{array}$ & $\begin{array}{l}1649.4 \\
0.454 \\
82.9\end{array}$ & $\begin{array}{l}1933.6 \\
0.569 \\
82.3\end{array}$ & $\begin{array}{l}1557.2 \\
0.525 \\
79.1\end{array}$ & $\begin{array}{l}1332.1 \\
0.554 \\
69.8\end{array}$ & $\begin{array}{l}1073.8 \\
0.539 \\
59.8\end{array}$ & $\begin{array}{l}952 \\
0.586 \\
54.0\end{array}$ \\
\hline \multicolumn{14}{|l|}{ south DaxtorA } \\
\hline 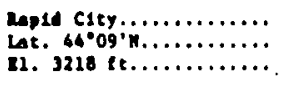 & $\begin{array}{l}\bar{I}_{H} \\
\tau_{t} \\
t_{0}\end{array}$ & $\begin{array}{l}687.8 \\
0.601 \\
24.7\end{array}$ & $\begin{array}{l}1032.5 \\
0.627 \\
27.6\end{array}$ & $\begin{array}{l}1303.7 \\
0.649 \\
36.7\end{array}$ & $\begin{array}{l}1807 \\
0.594 \\
48.2\end{array}$ & $\begin{array}{l}.2028 \\
0.574 \\
58.3\end{array}$ & $\begin{array}{l}2193.7 \\
0.583 \\
67.3\end{array}$ & $\begin{array}{l}2235.8 \\
0.612 \\
76.3\end{array}$ & $\begin{array}{l}2019.9 \\
0.622 \\
75.0\end{array}$ & $\begin{array}{l}1+28 \\
0.628 \\
64.7\end{array}$ & $\begin{array}{l}1179.3 \\
0.624 \\
52.9\end{array}$ & $\begin{array}{l}763.1 \\
0.566 \\
38.7\end{array}$ & $\begin{array}{l}590.4 \\
0.588 \\
29.2\end{array}$ \\
\hline Trans & & & & & & & & & & & & & \\
\hline 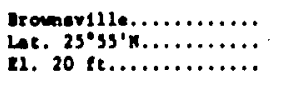 & $\begin{array}{l}\overline{\underline{I}}_{\mathrm{k}} \\
\mathrm{t}_{\mathrm{t}}\end{array}$ & $\begin{array}{l}1105.9 \\
0.517 \\
63.3\end{array}$ & $\begin{array}{l}1262.7 \\
0.500 \\
66.7\end{array}$ & $\begin{array}{l}1505.9 \\
0.505 \\
70.7\end{array}$ & $\begin{array}{l}1714 \\
0.309 \\
76.2\end{array}$ & $\begin{array}{l}2092.2 \\
0.584 \\
81.4\end{array}$ & $\begin{array}{l}2288.5 \\
0.627 \\
85.1\end{array}$ & $\begin{array}{l}2365 \\
0.650 \\
86.5\end{array}$ & $\begin{array}{l}2124 \\
0.617 \\
86.9\end{array}$ & $\begin{array}{l}1774.9 \\
0.566 \\
84.1\end{array}$ & $\begin{array}{l}1536.5 \\
0.570 \\
78.9\end{array}$ & $\begin{array}{l}1104.8 \\
0.468 \\
70.7\end{array}$ & $\begin{array}{l}982.3 \\
0.488 \\
65.2\end{array}$ \\
\hline 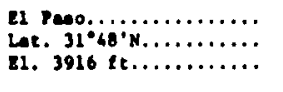 & $\begin{array}{l}\overline{\bar{I}_{H}} \\
\bar{X}_{\mathrm{t}} \\
\mathbf{t}_{0}\end{array}$ & $\begin{array}{l}1247.6 \\
0.686 \\
47.1\end{array}$ & $\begin{array}{l}1612.9 \\
0.714 \\
53.1\end{array}$ & $\begin{array}{l}2048.7 \\
0.730 \\
58.7\end{array}$ & $\begin{array}{l}2447.2 \\
0.741 \\
67.3\end{array}$ & $\begin{array}{l}2673 \\
0.743 \\
75.7\end{array}$ & $\begin{array}{l}2731 \\
0.733 \\
84.2\end{array}$ & $\begin{array}{l}2391.1 \\
0.652 \\
84.9\end{array}$ & $\begin{array}{l}2350.5 \\
0.669 \\
83.4\end{array}$ & $\begin{array}{l}2077.5 \\
0.693 \\
78.5\end{array}$ & $\begin{array}{l}1704.8 \\
0.695 \\
69.0\end{array}$ & $\begin{array}{l}1324.7 \\
0.647^{7} \\
56.0\end{array}$ & $\begin{array}{l}1051.6 \\
0.626 \\
48.5\end{array}$ \\
\hline 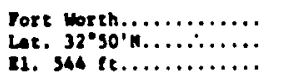 & $\begin{array}{l}\overline{I_{H}} \\
\bar{x}_{t} \\
t_{0}\end{array}$ & $\begin{array}{l}936.2 \\
0.530 \\
48.1\end{array}$ & $\begin{array}{l}1198.5 \\
0.541 \\
52.3\end{array}$ & $\begin{array}{l}1597.8 \\
0.577 \\
59.8\end{array}$ & $\begin{array}{l}1829.1 \\
0.556 \\
68.8\end{array}$ & $\begin{array}{l}2105.1 \\
0.585 \\
75.9\end{array}$ & $\begin{array}{l}2437.6 \\
0.65 \% \\
84.0\end{array}$ & $\begin{array}{l}2293.3 \\
0.624 \\
87.7\end{array}$ & $\begin{array}{l}2216.6 \\
0.653 \\
88.6\end{array}$ & $\begin{array}{l}1880.8 \\
0.634 \\
81.3\end{array}$ & $\begin{array}{l}1476 \\
0.612 \\
71.5\end{array}$ & $\begin{array}{l}1147.6 \\
0.576 \\
58.8\end{array}$ & $\begin{array}{l}913.6 \\
0.563 \\
50.8\end{array}$ \\
\hline
\end{tabular}


TEus (Coned.)

Midland...............

I1. 2854 8t..............

San Antonto...........

Lat. $29^{\circ} 32^{\prime}$

E1. 794 Et............

Tumesset

taches

Lat. $36^{\circ} 07$ ' n..........

oek Redge...............

Let. $36^{\circ} 01$ '

E1. 905 it.

vran

Selt take city.........

Let. $40^{\circ} 46^{\prime} 14$.

1.........

I.

seactle................

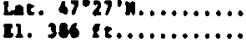

seartle.............

Let. 47036 'n...........

E1. $14 \mathrm{tt}$.

Spoknas..........

11.1968 et..............

Irxansin

Musteon..

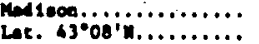

B2. 166 te............

Manrex

Lander................

L1. 5370 \& $42^{\circ} 4 . \ldots \ldots \ldots \ldots$
Jan Fab

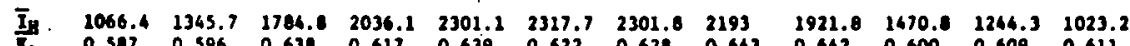
$\begin{array}{llllllllllll}0.507 & 0.596 & 0.638 & 0.617 & 0.639 & 0.622 & 0.628 & 0.643 & 0.642 & 0.600 & 0.609 & 0.611 \\ 67.9 & 32.8 & 60.0 & 68.8 & 77.2 & 83.9 & 85.7 & 85.0 & 78.9 & 70.3 & 56.6 & 49.1\end{array}$

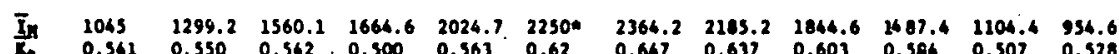
$\begin{array}{llllllllllll}0.561 & 0.550 & 0.562 & 0.500 & 0.563 & 0.62 & 0.647 & 0.637 & 0.603 & 0.596 & 0.507 & 0.528 \\ 33.7 & 58.4 & 65.0 & 72.2 & 19.2 & 85.0 & 87.6 & 87.0 & 82.6 & 74.7 & 63.3 & 36.5\end{array}$

\begin{tabular}{lllllllllllllll}
\hline & 509.7 & 907 & 2246.8 & 1662.3 & 1997 & 2149 & 2079.7 & 1262.7 & 1600.7 & 1223.6 & 023.2 & 614.4
\end{tabular}

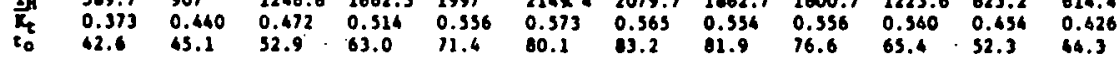

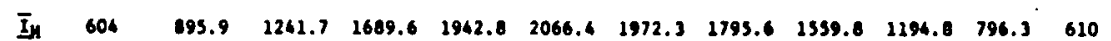

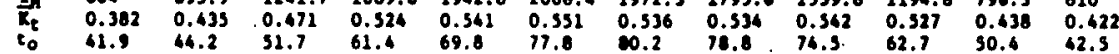

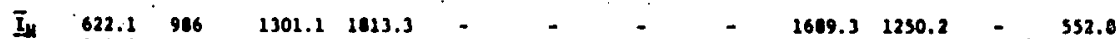

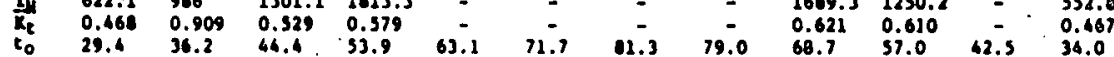

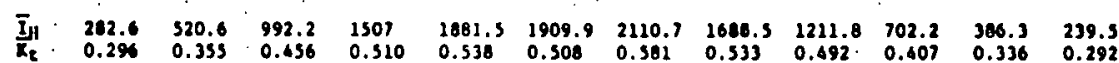
$\begin{array}{lllllllllllll}x_{t} & 0.296 & 0.353 & 0.456 & 0.510 & 0.538 & 0.508 & 0.301 & 0.533 & 0.492 & 0.407 & 0.336 & 0.292 \\ t_{0} & 42.1 & 45.0 & 48.9 & 54.1 & 59.8 & 64.4 & 68.4 & 67.9 & 63.3 & 36.3 & 46.4 & 64.4\end{array}$

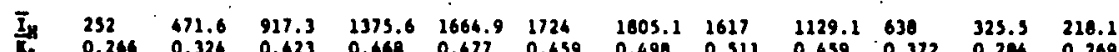

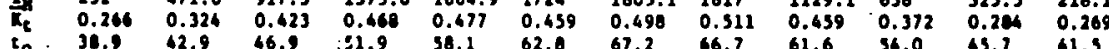

$\bar{I}_{H} \quad 406.1 \quad 37.6 \quad 1200 \quad 1864.6 \cdot 2104.4 \quad 2226.5 \quad 2479.7 \quad 2076 \quad 1311 \quad 044.6 \quad 486.3 \quad 279$

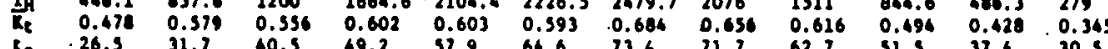
,

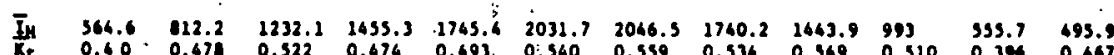

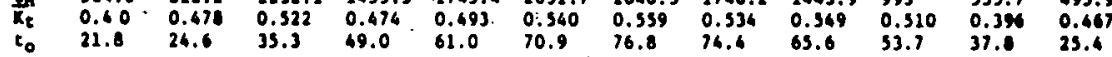

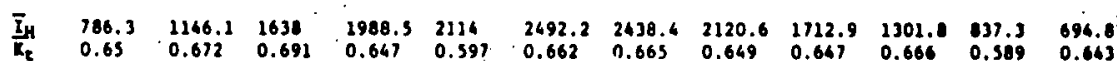
$\begin{array}{lllllllllllll}\mathrm{R}_{\mathrm{t}} & 0.65 & 0.672 & 0.691 & 0.647 & 0.397 & 0.662 & 0.665 & 0.669 & 0.667 & 0.666 & 0.389 & 0.663 \\ \mathrm{t}_{0} & 20.2 & 26.3 & 34.7 & 45.5 & 36.0 & 65.6 & 76.6 & 72.5 & 61.4 & 46.3 & 33.4 & 23.6\end{array}$

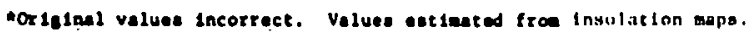


THIS PAGE

\section{WAS INTENTIONALLY LEFT BLANK}




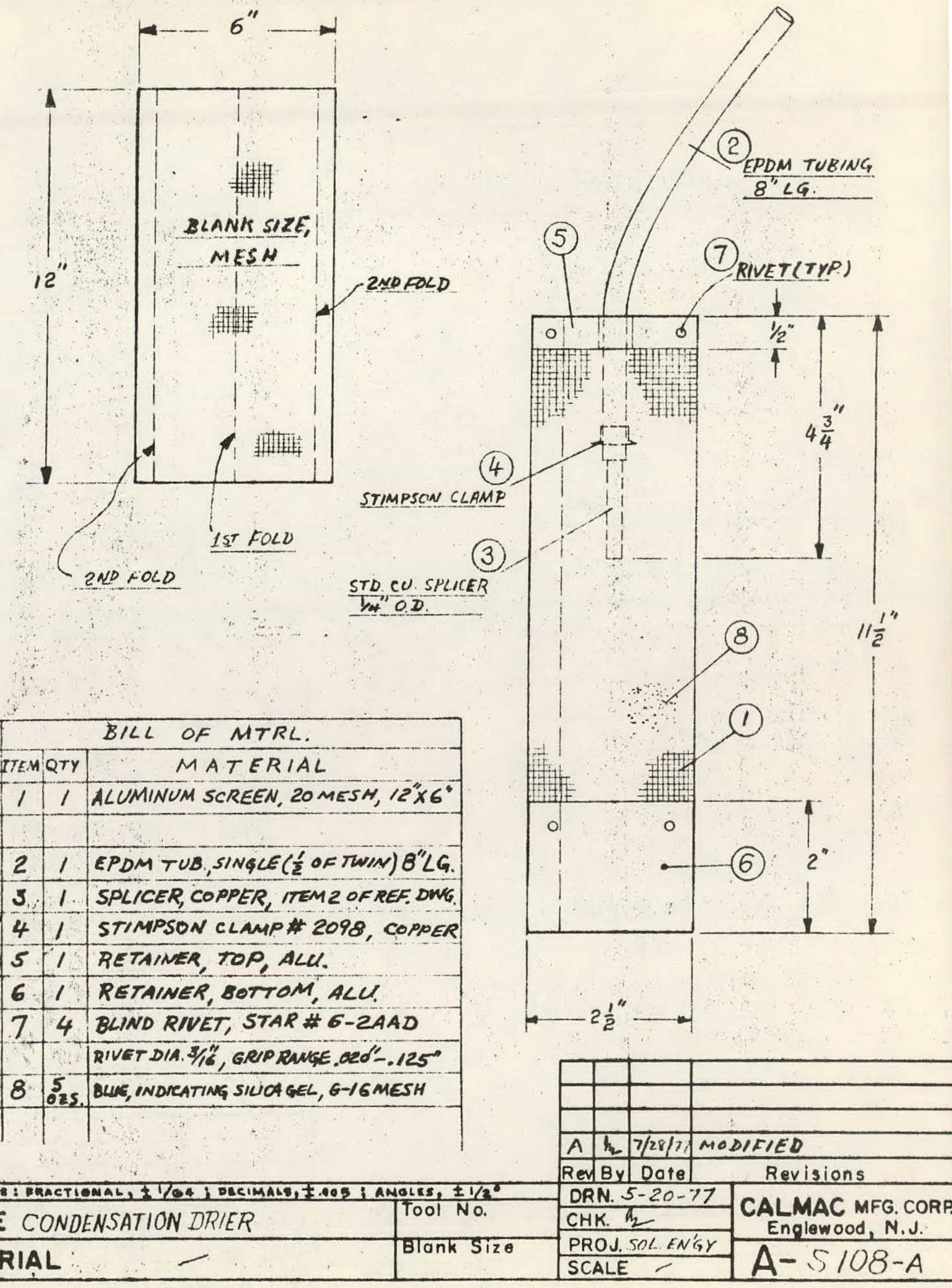




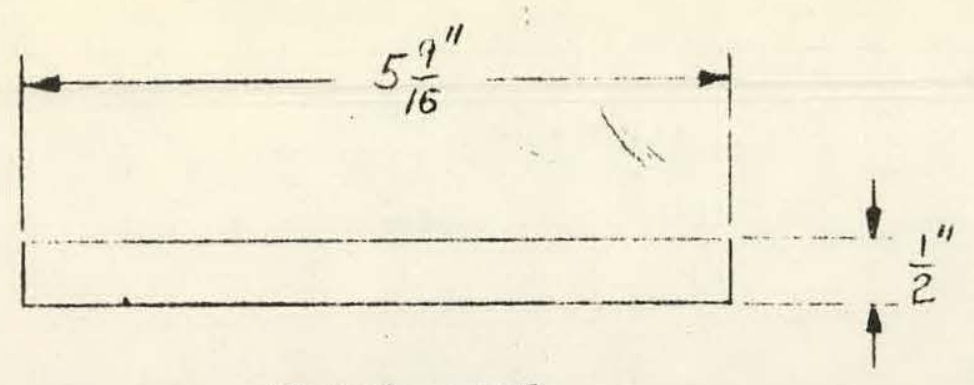

BLANH SIZE

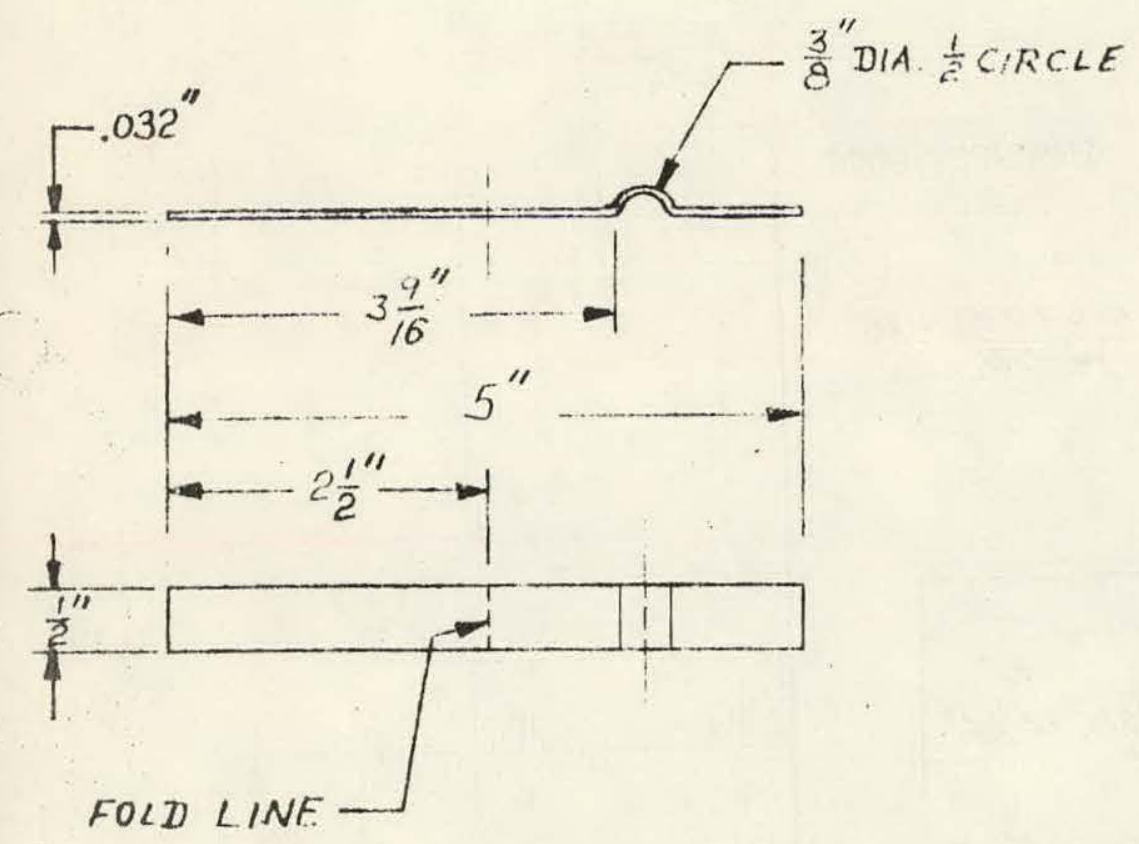

UN FOLDED FORMED

VIEWS

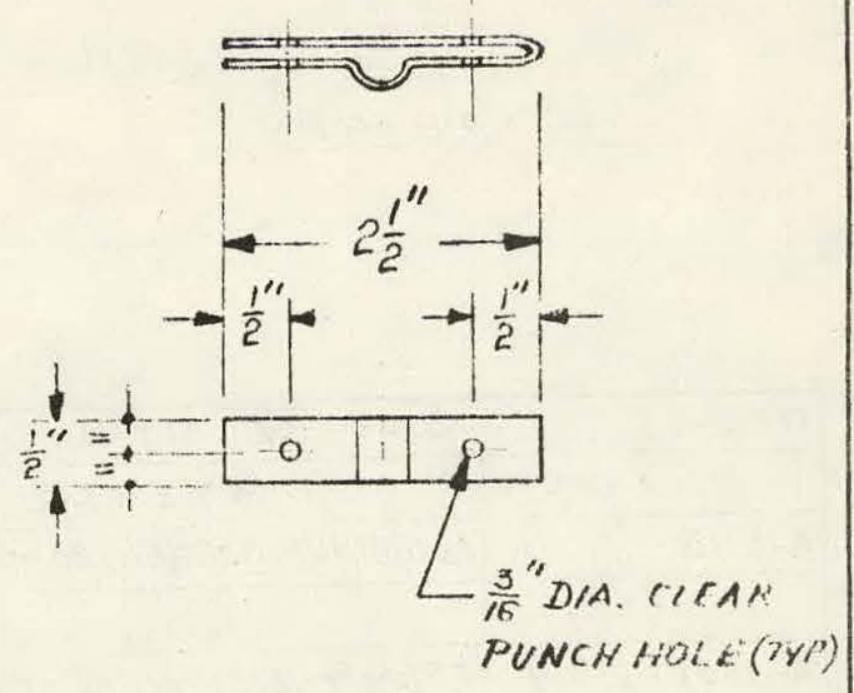

FOLDED FINISHED VIEWS

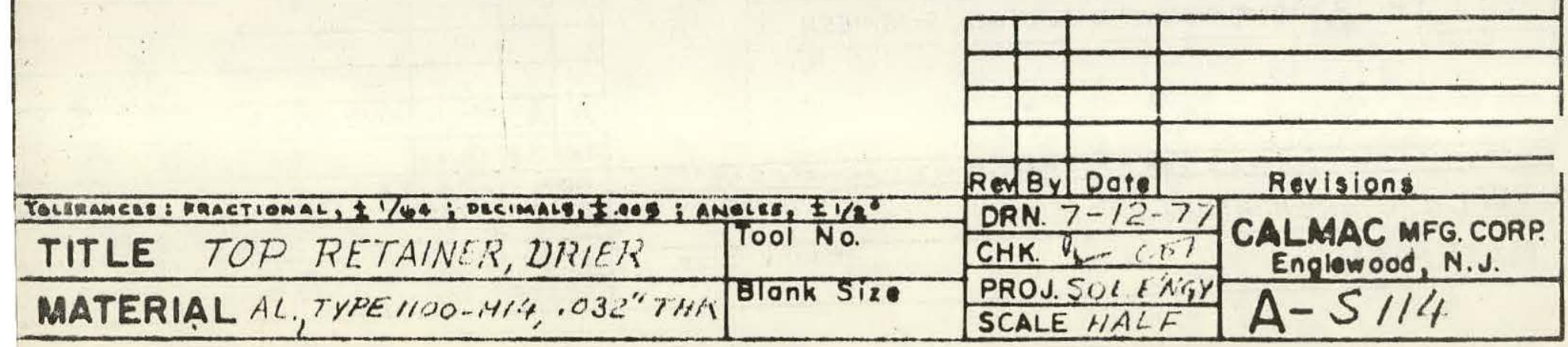




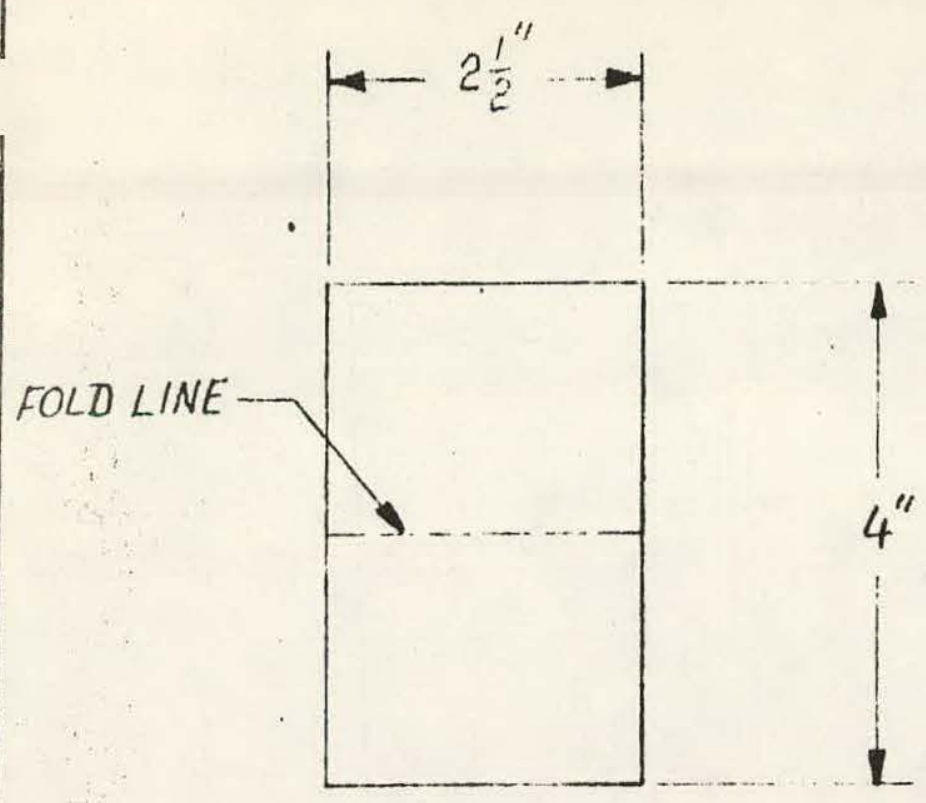

BLANK S/2E

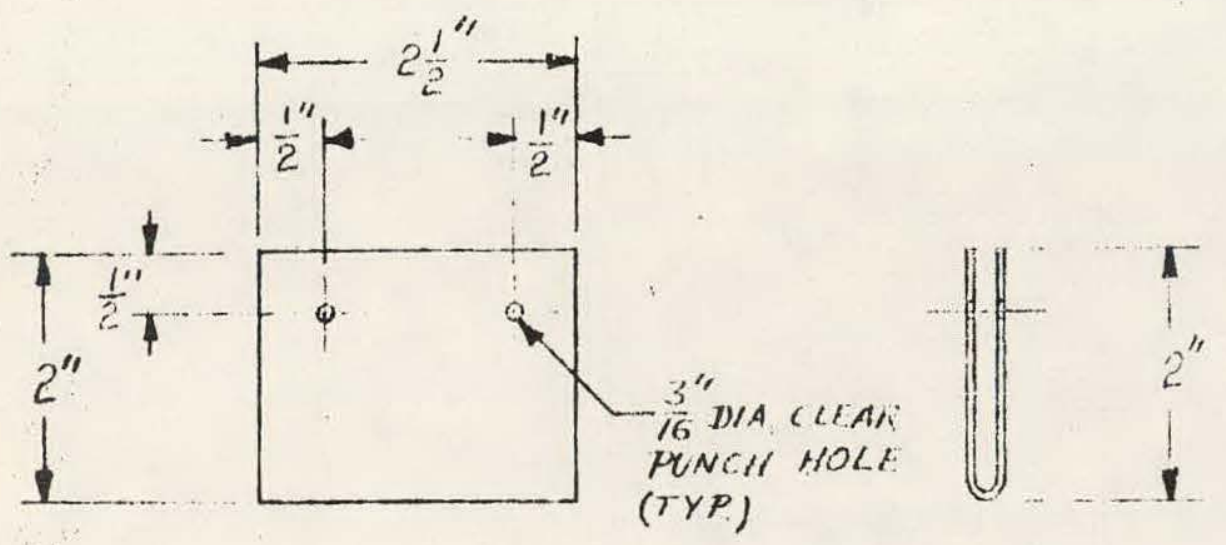

$$
\frac{\text { FRONT VIEW }}{\text { (FOLDED) }} \frac{\text { END VIEW }}{\text { (tOLDER: }}
$$

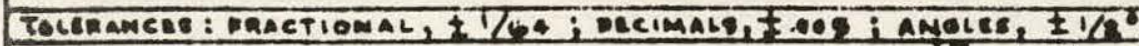

TITLE BOTYON RETAINER, COND DRIA

MATERIAL AL, TYPE $\| O O-H 14, .033^{\prime \prime} \mathrm{THA}$
Blank Size

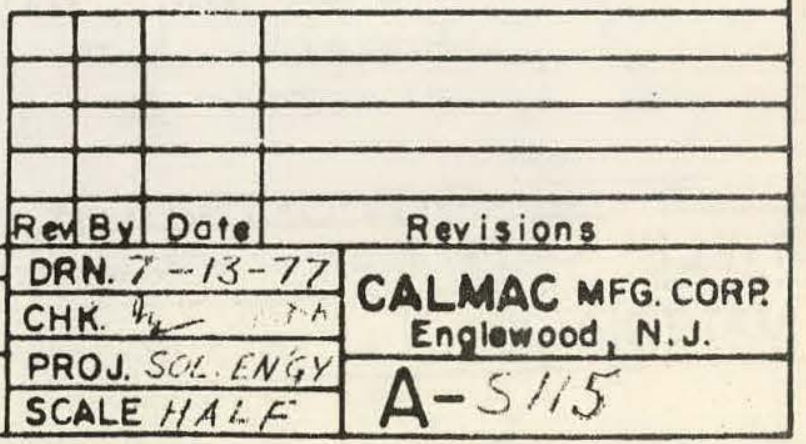




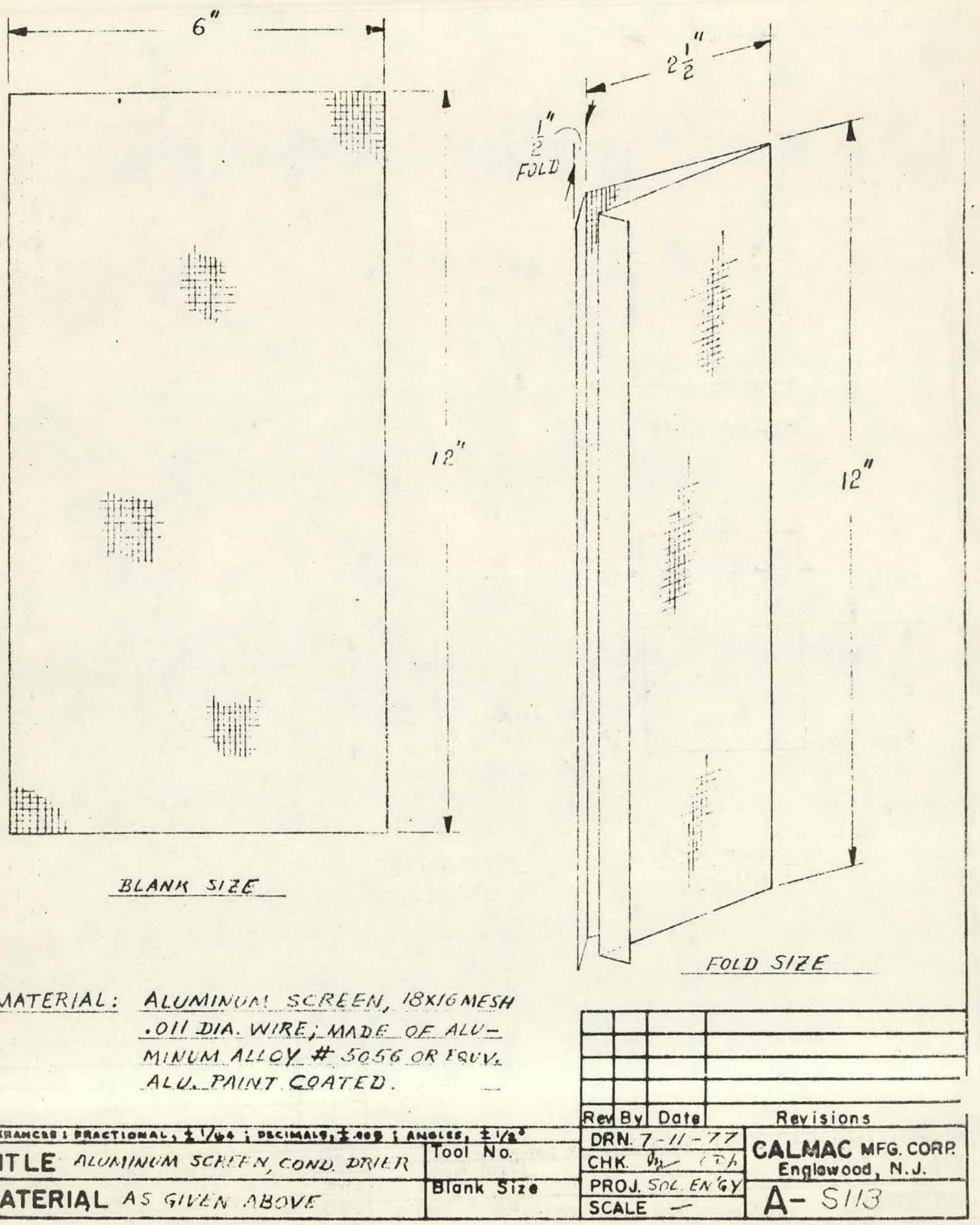




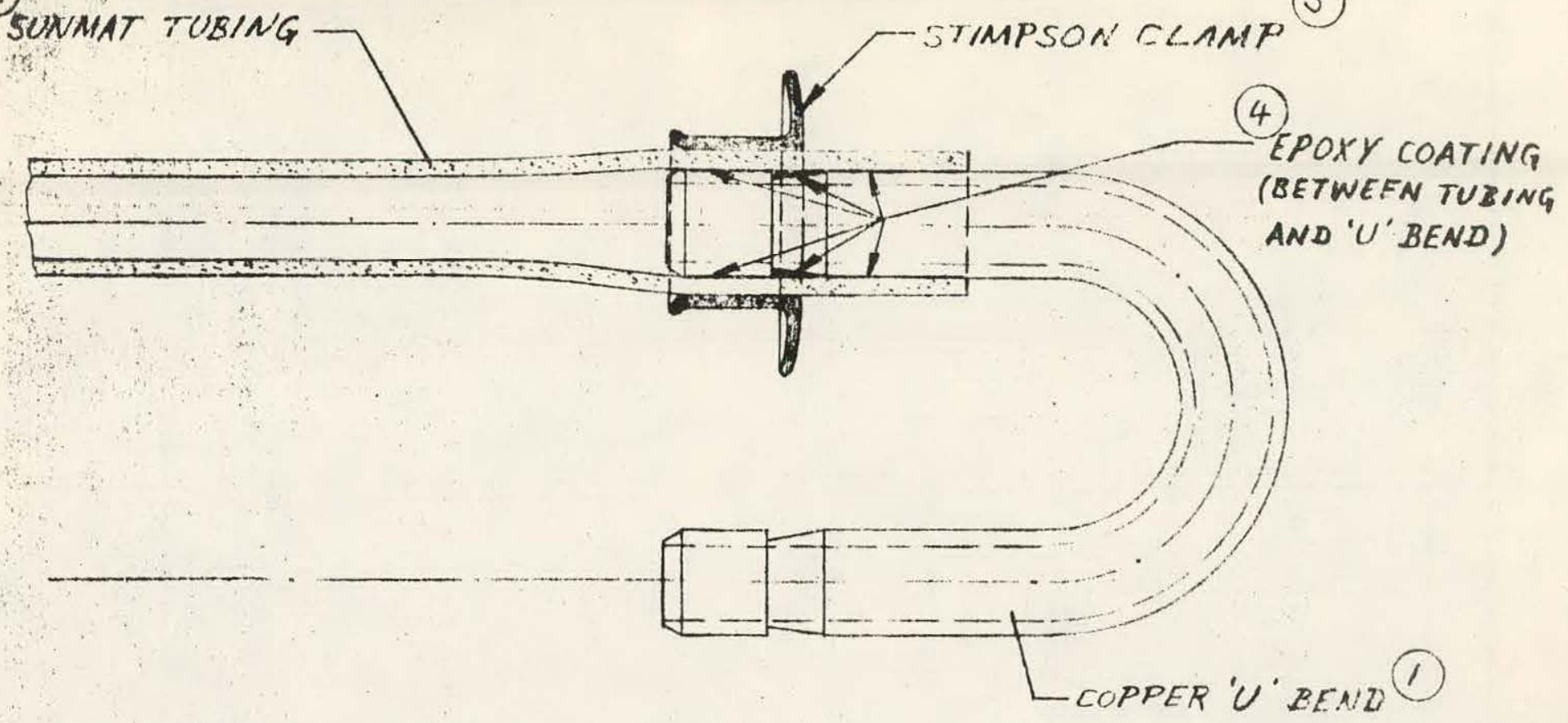

KOK CHIMICALS 4 AS KOK CHEMICALS'ADHESIVE \# $305-1$ MIXED DATA SH'TS. STIMPSDT CAT WITH HARDNER \# 305-2 DWG $* A$ SIII $A-130 P$ $A-5118$ 32 STIMPSON CLAMP \# A20?8 COPPER 21 SUNMAT TWIN TUBING 11 COPPER ' $U$ 'BEND MATERIAL BILL OF MATERIAL

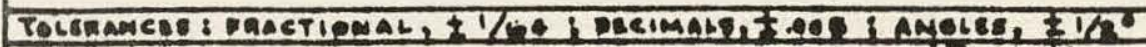

TITLE 'U'-BEND END ASS'LY, SINNAIAT MATERIAL AS SPEC.

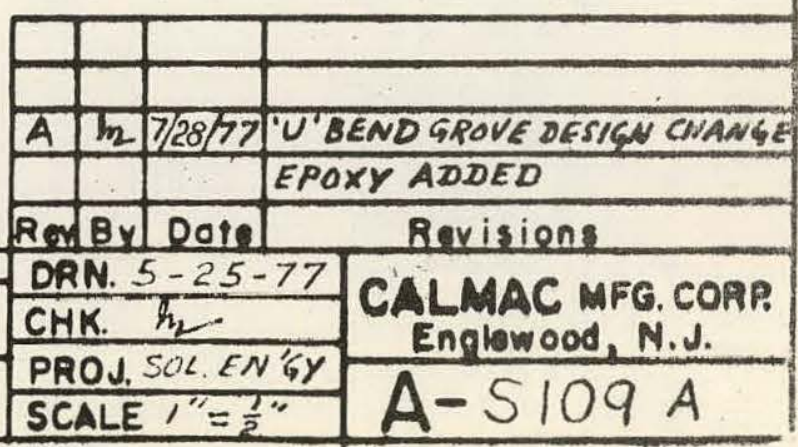




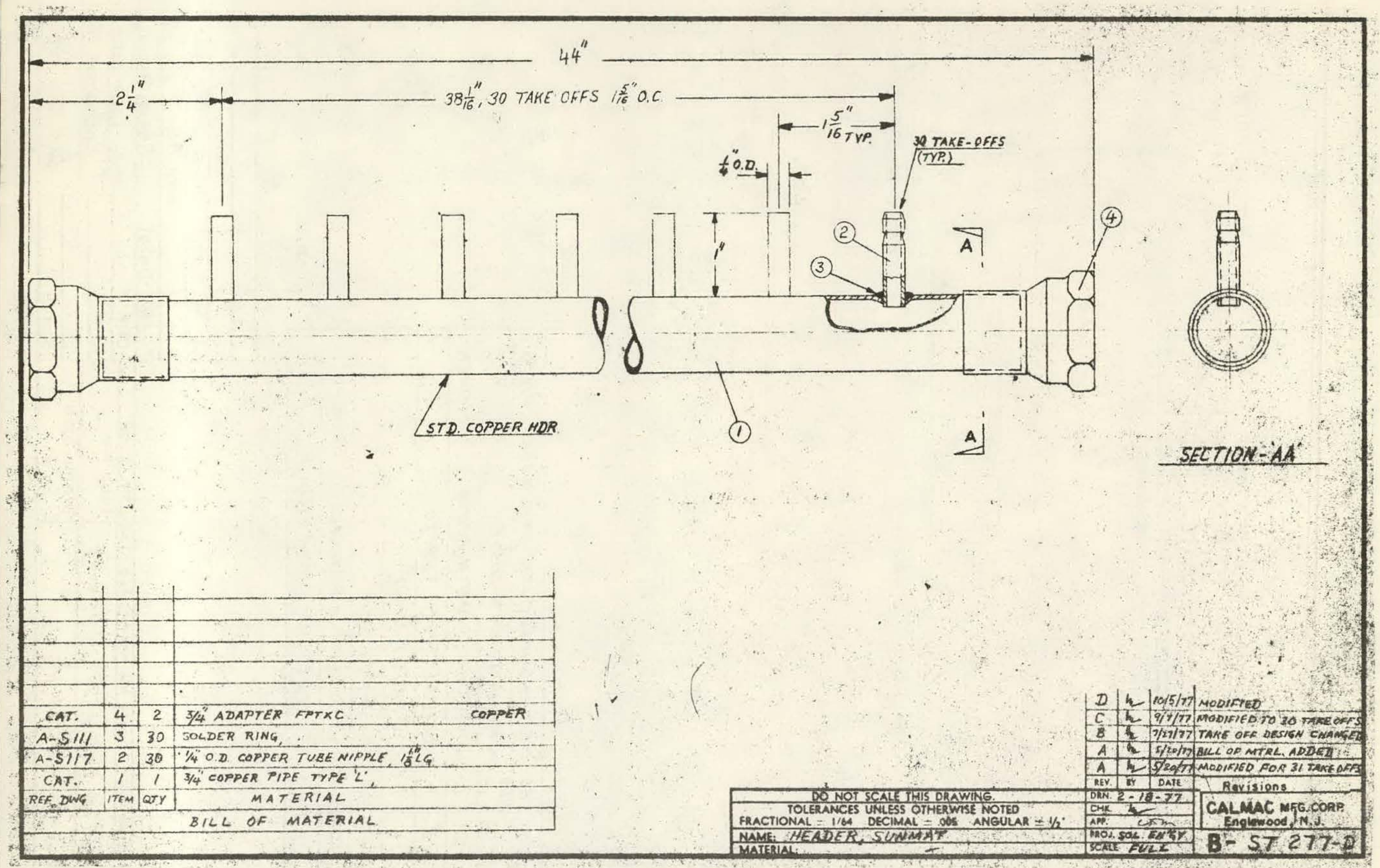




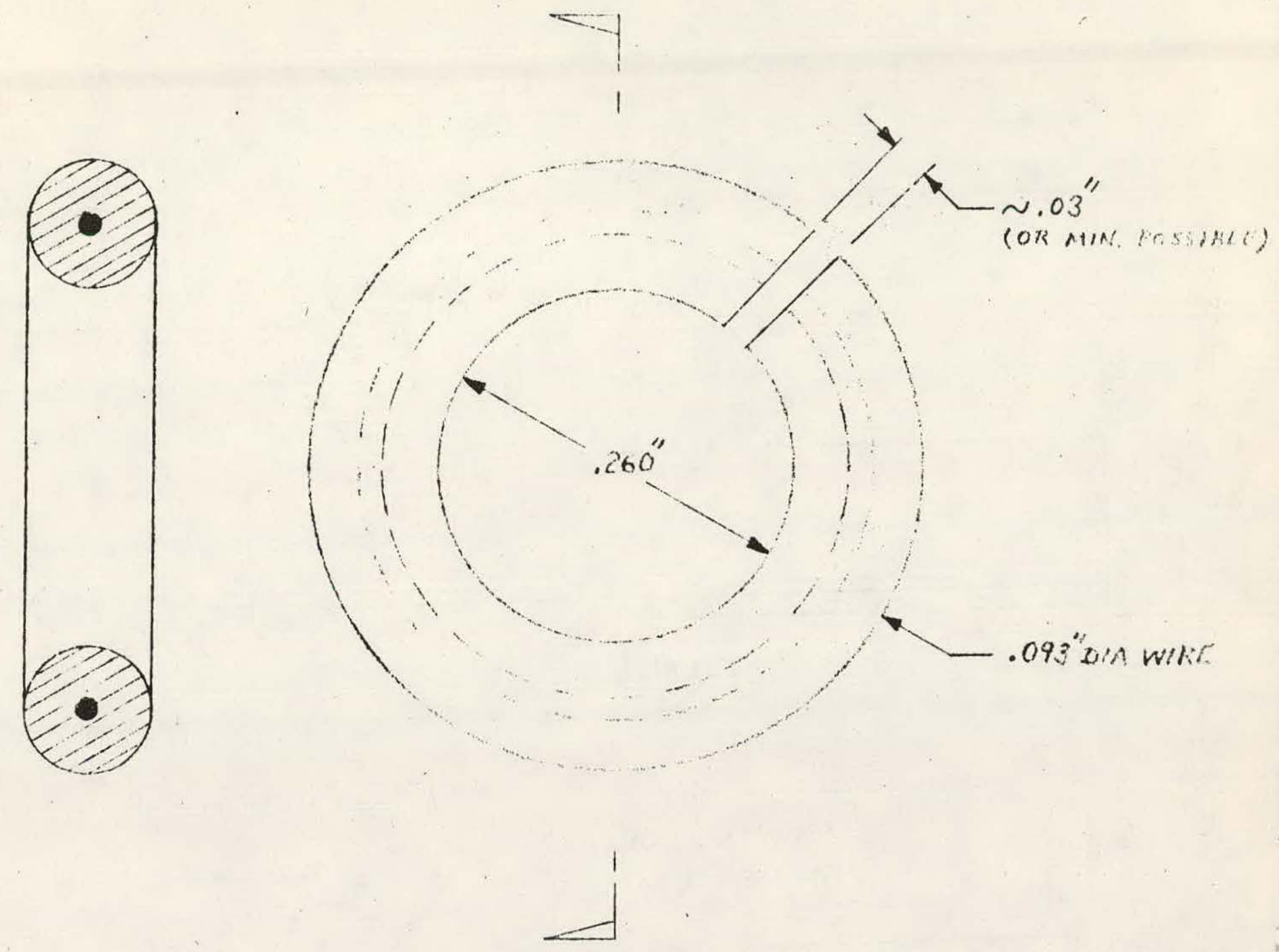

MATERIAL: $\quad 40 \%$ TIN, $60 \% \angle E A D$

WITH $2.5 \%$ (MEDIUNI) ROSIN CORE FLUX

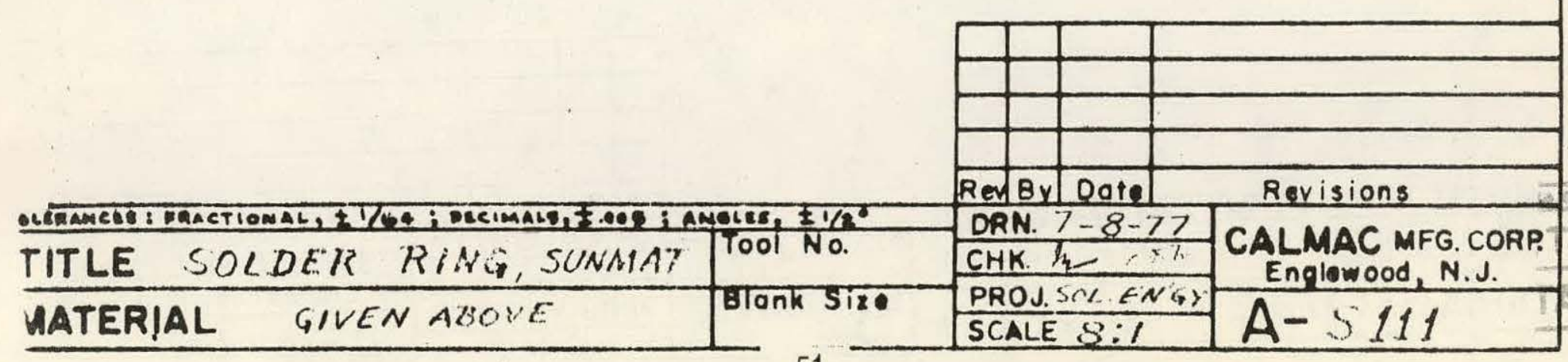



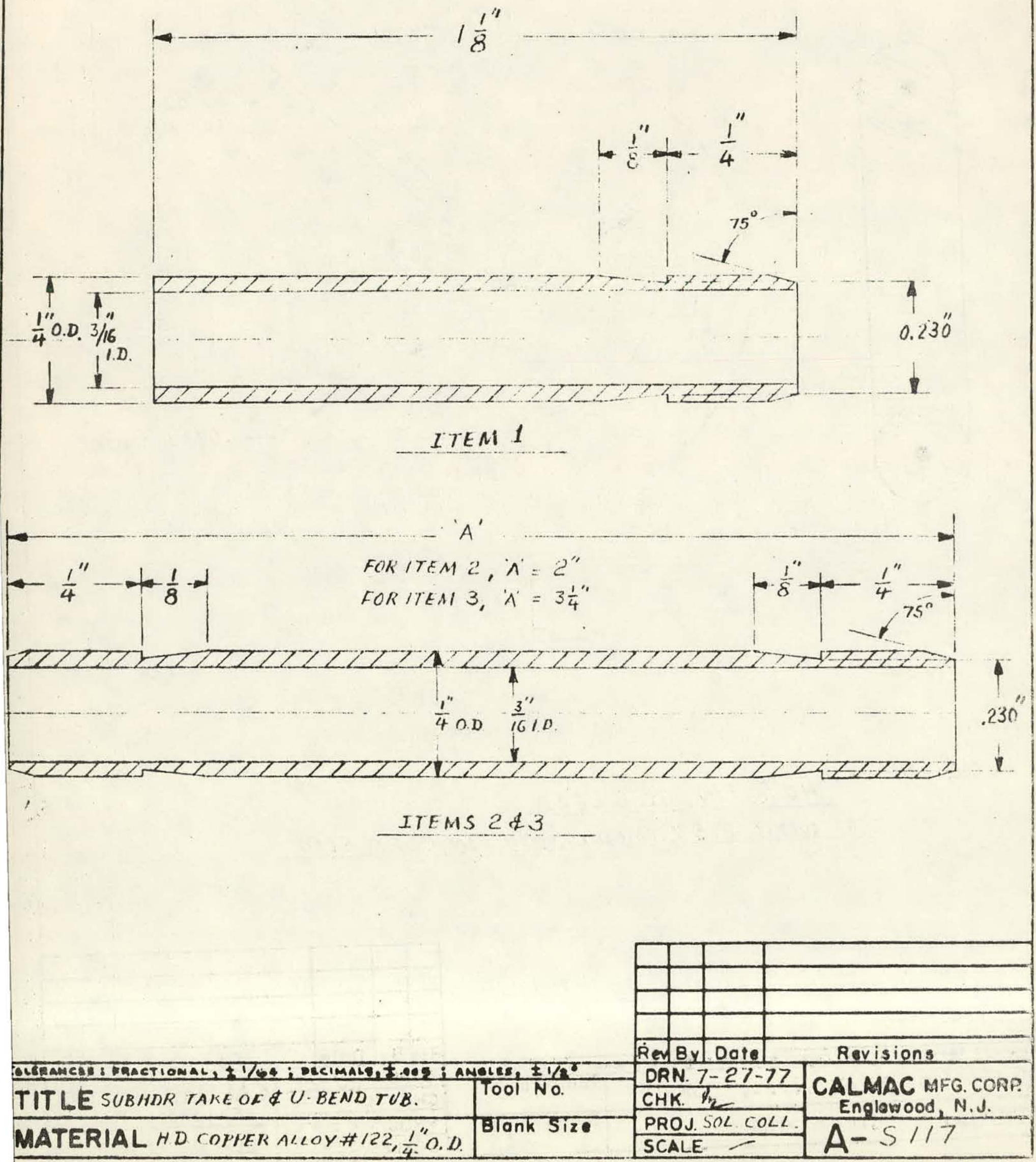

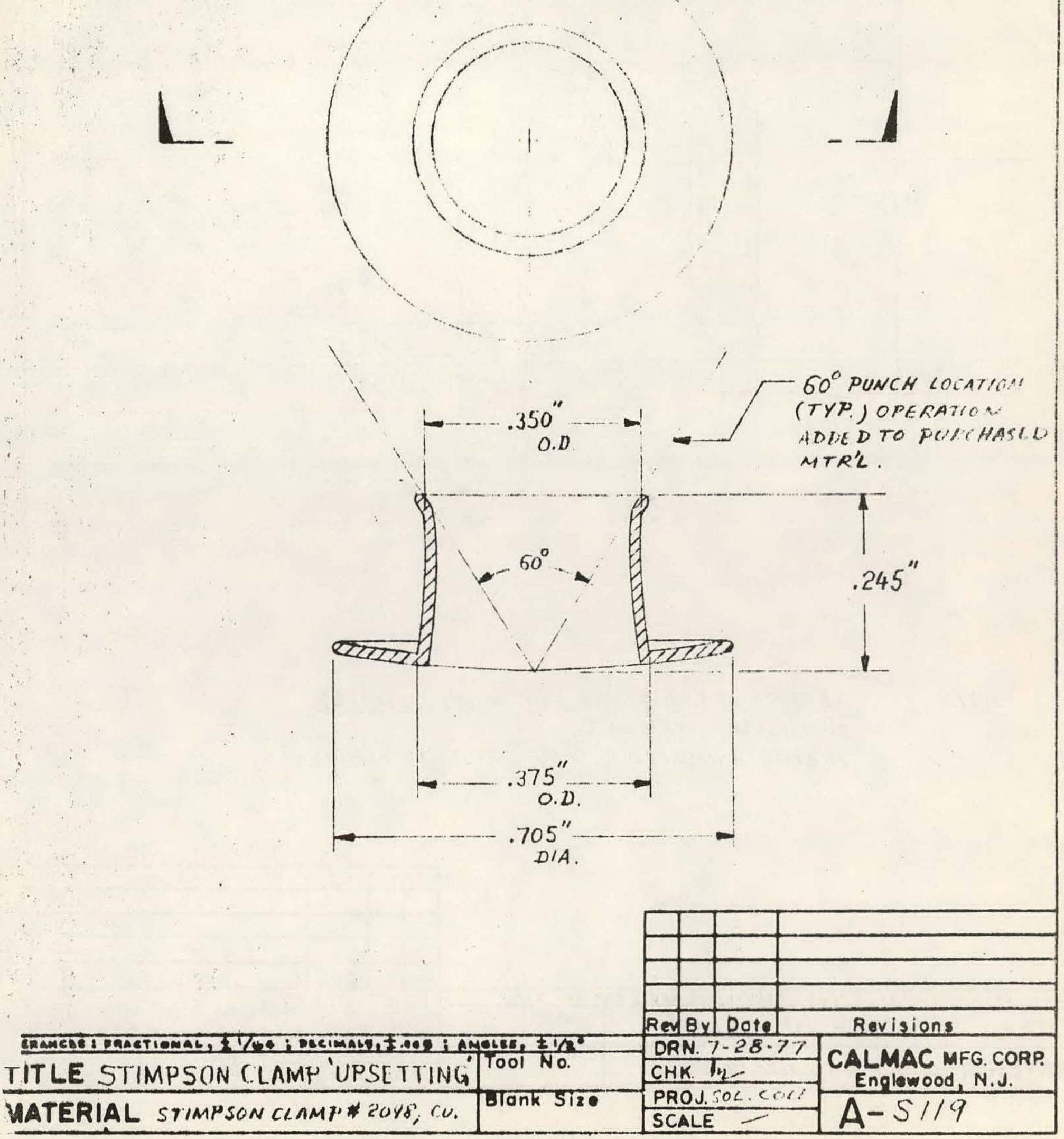


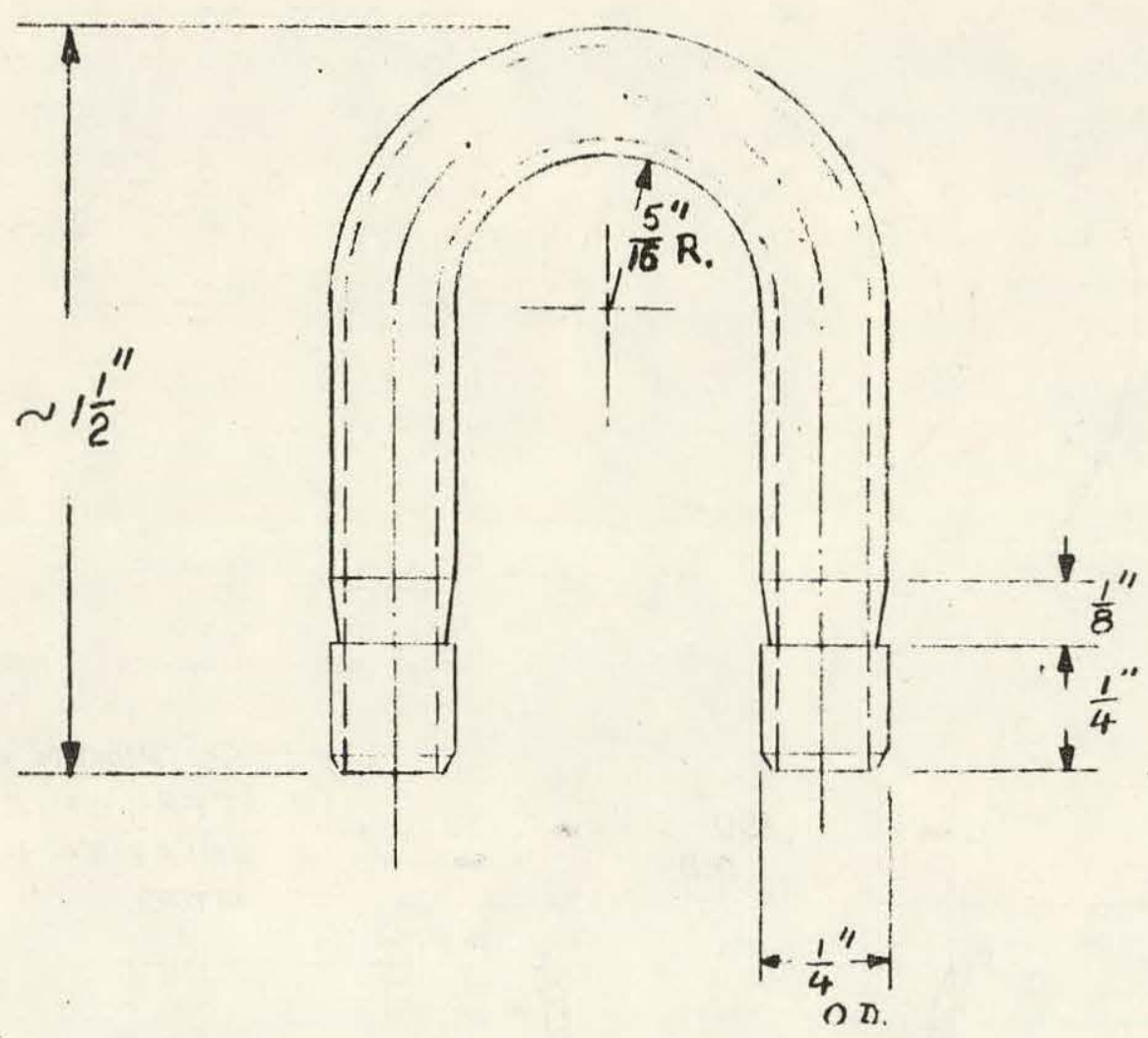

NOTE: REFER DWF. \#ASII7 FOR MORE DETAILED DIMENSIONS. ITEM \# 3

TUBING ANNEALED O $500 \%$ PRIOT TO BENDING:

\begin{tabular}{|c|c|c|c|}
\hline \multirow{2}{*}{\multicolumn{2}{|c|}{ 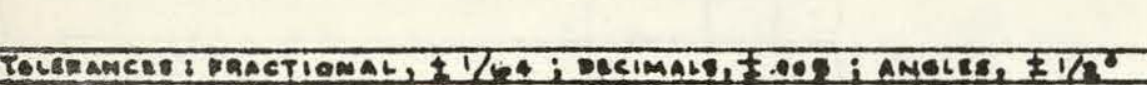 }} & Red $B y]$ Dafo & Reyisions \\
\hline & & DRN. $7-27-77$ & \multirow{2}{*}{$\begin{array}{c}\text { CALAMAC MFG. CO. } \\
\text { Englovood, N.J. }\end{array}$} \\
\hline TITLE COPPER 'U' EEND & Tool No. & CHK. he & \\
\hline MATERIAL $\frac{1}{4}{ }^{\prime O O D}$ H.D. CU.ALCOY 182. & Blonk Sizo & $\frac{\text { PROJ.SOL COLL }}{\text { SCALE } I^{\prime \prime}=\frac{1}{2}}$ & $A=5 / 18$ \\
\hline
\end{tabular}



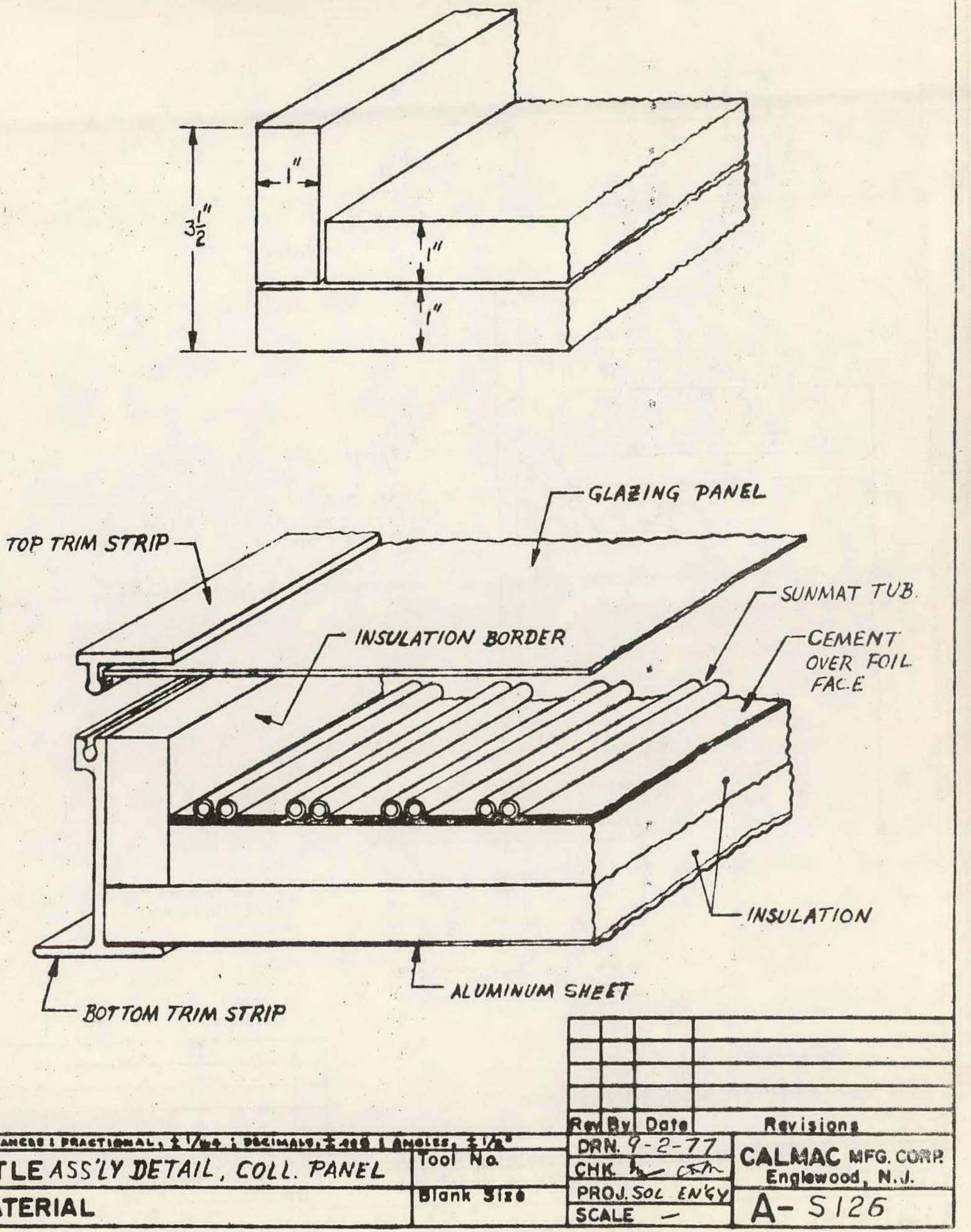


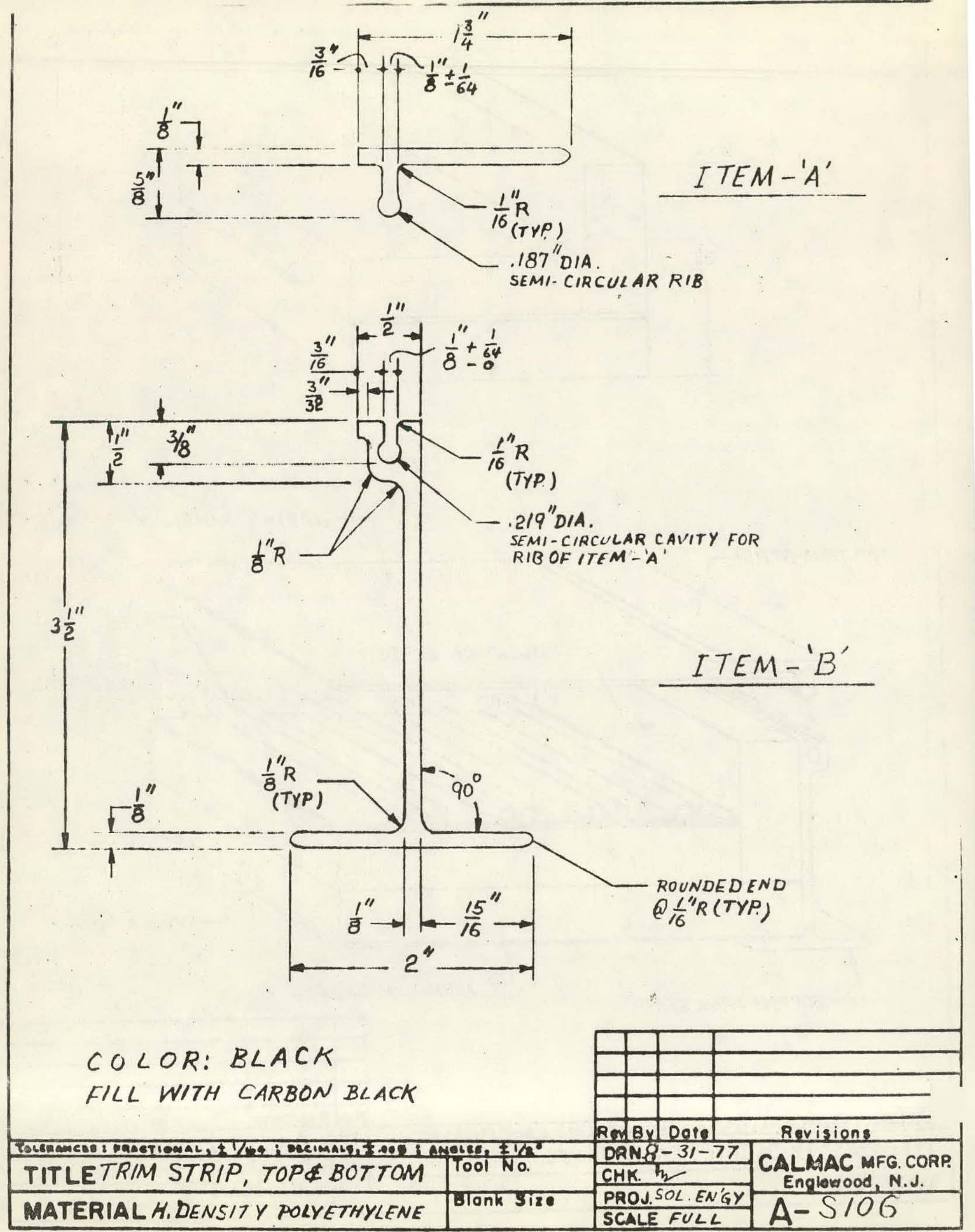




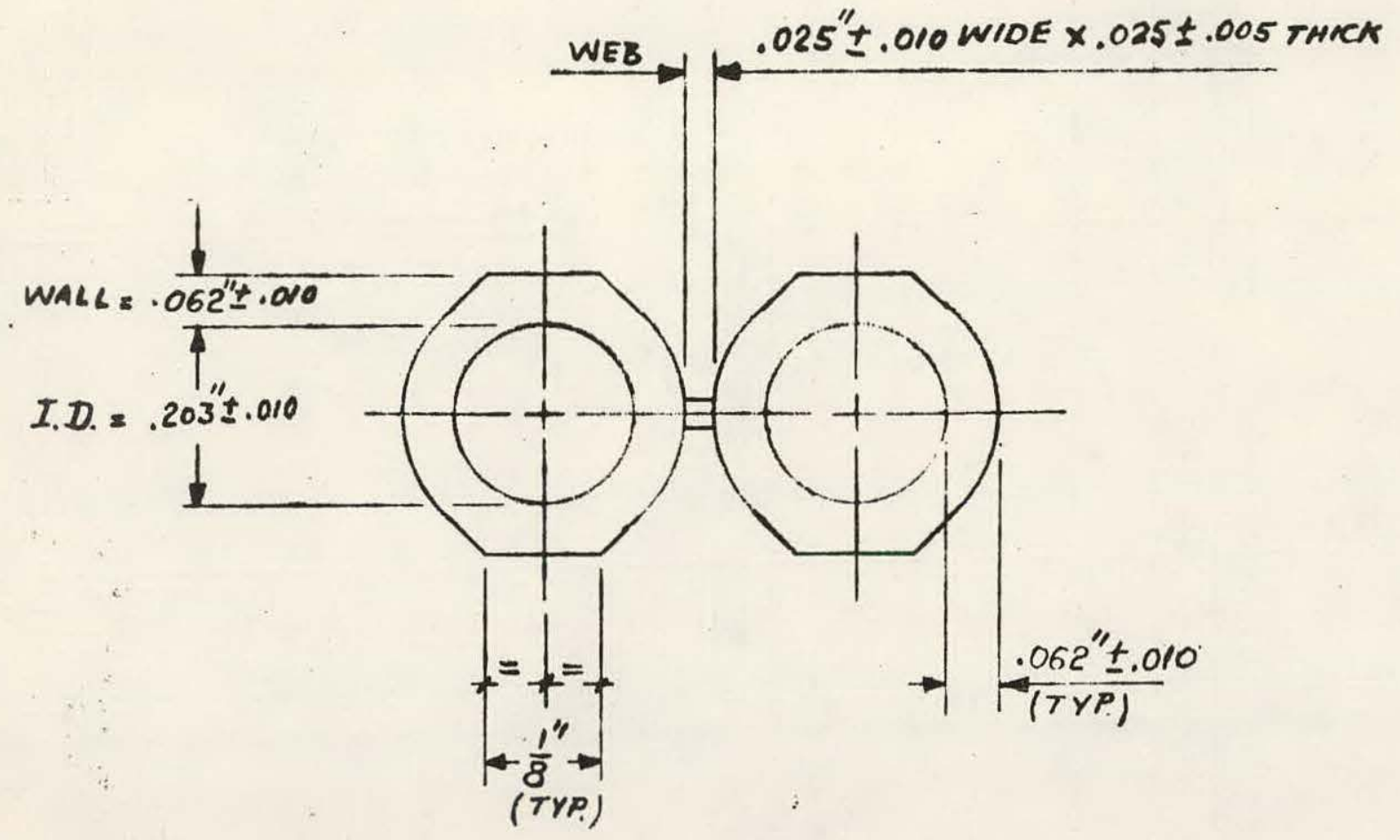

EPDM rubber dual tubing

Tensile strength, 1000-1200 psi

Elongation, 100-150\%

Durometer(shore AZ hardness) 84-88

$100 \%$ Modulus 900-1000 psi

Color- Black

Carbon black $50 \%$ loading

Cure continuous salt bath

Reel capactty $2200 \mathrm{ft}$.

Compression set $30 \%$

Ozone resistance 0 ASTM

Non-staining

Non-fire resistant

Non-oil resistant

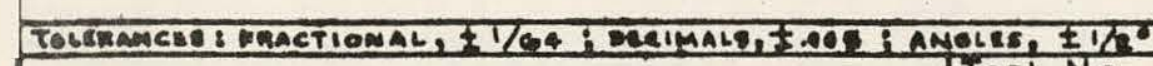
TITLE TWIN TUBING - CROSS SECTION TOO NO. MATERIALOO-OT DUROMETER EPDM

Dानnk SIz-

\begin{tabular}{|c|c|c|c|c|}
\hline & & & & \\
\hline & & & \multirow{2}{*}{\multicolumn{2}{|c|}{$\begin{array}{l}\text { WALLSDIMNDE FLAIENED PARI } \\
\text { MODIFIED }\end{array}$}} \\
\hline$\frac{1}{A}$ & & & & \\
\hline Res: & By & Dotel & \multicolumn{2}{|c|}{ Revisions } \\
\hline$\frac{D F}{C H}$ & $\frac{\text { M. }}{\mathrm{K} . \mathrm{S}}$ & $\frac{2-13-}{2}$ & \multicolumn{2}{|r|}{$\begin{array}{l}\text { CALMAC MFG. CORP. } \\
\text { Englowood, N.J. }\end{array}$} \\
\hline & $\frac{O J}{A L E}$ & $\frac{O L . E N}{4=1}$ & & $A-130 P-B$ \\
\hline
\end{tabular}




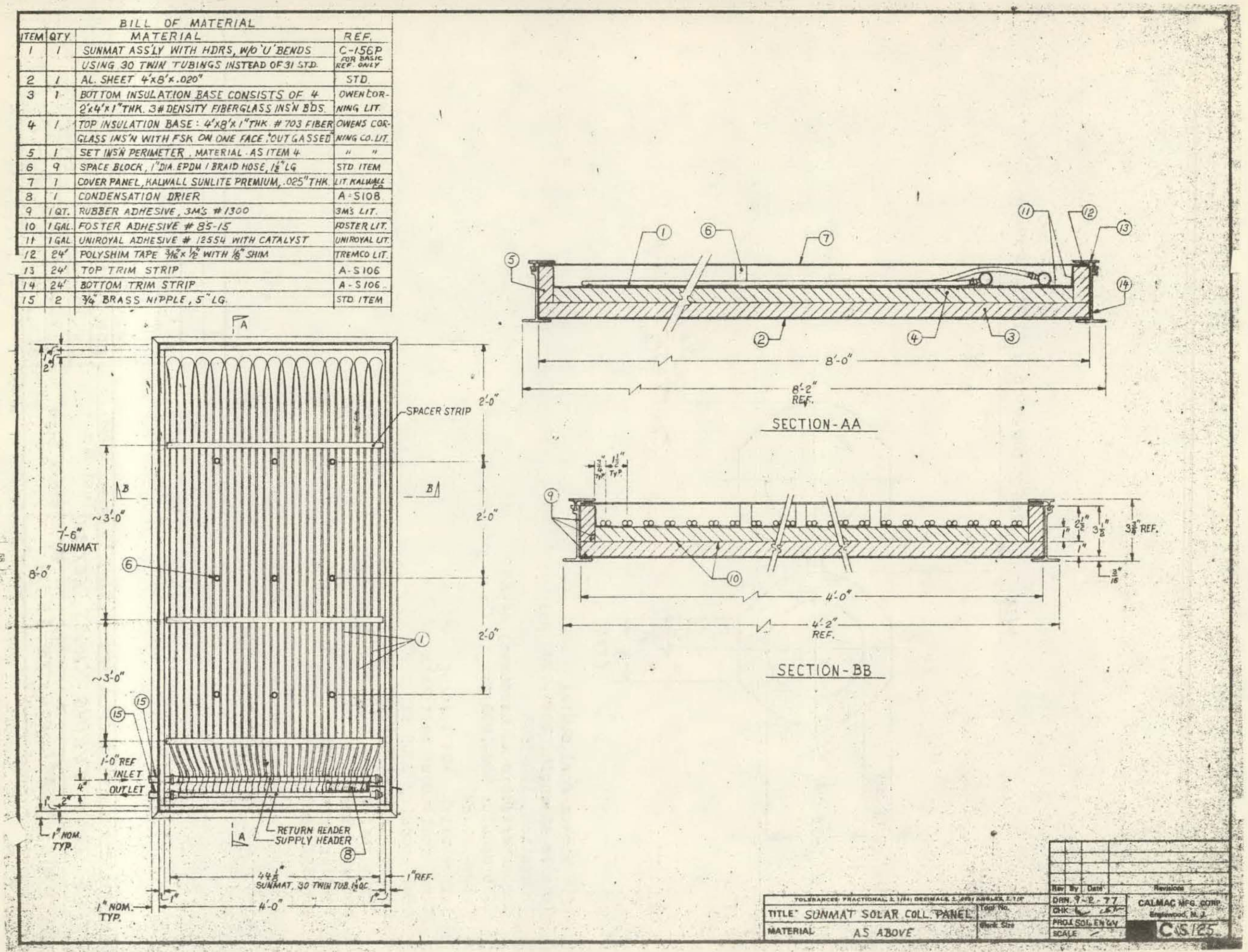




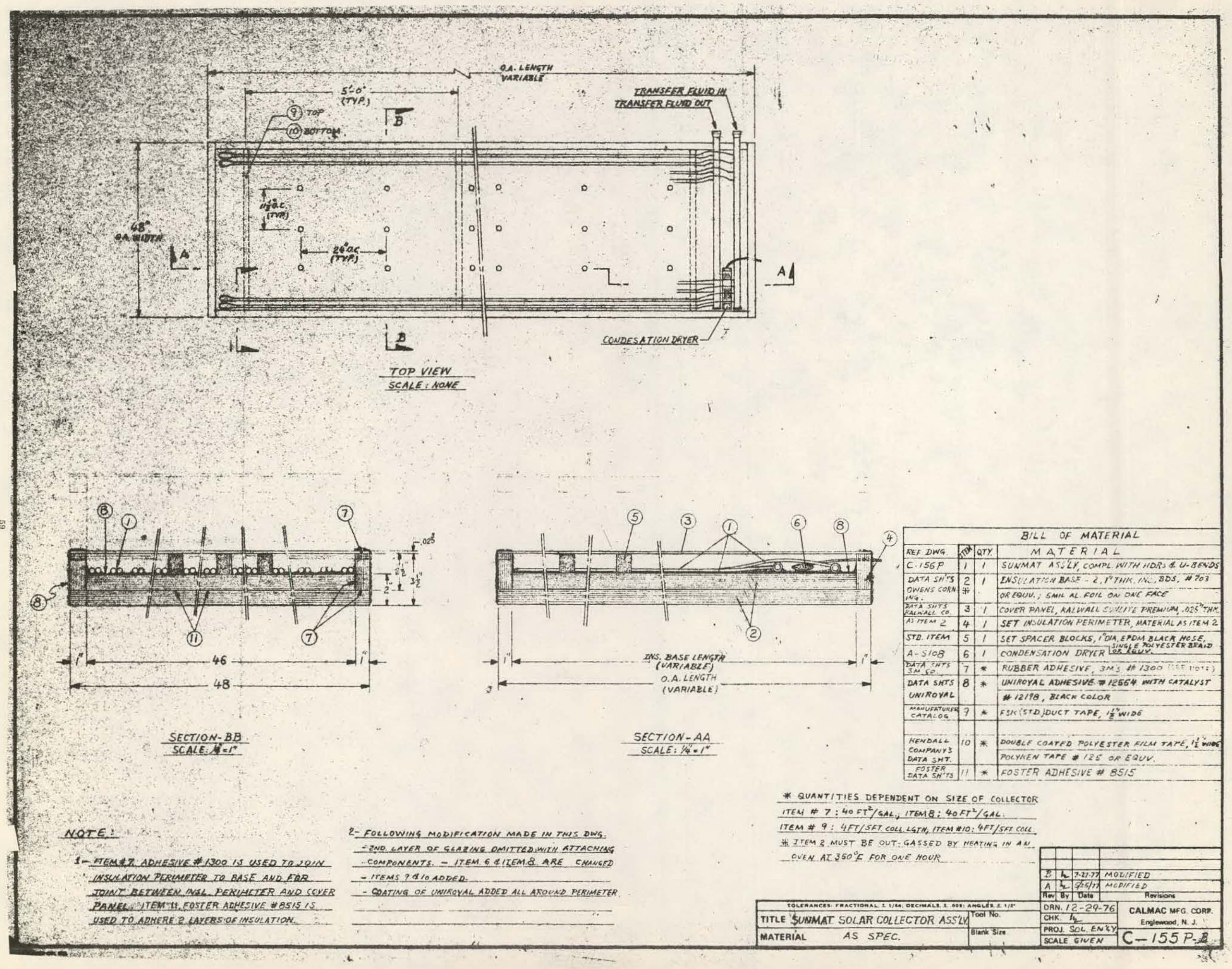




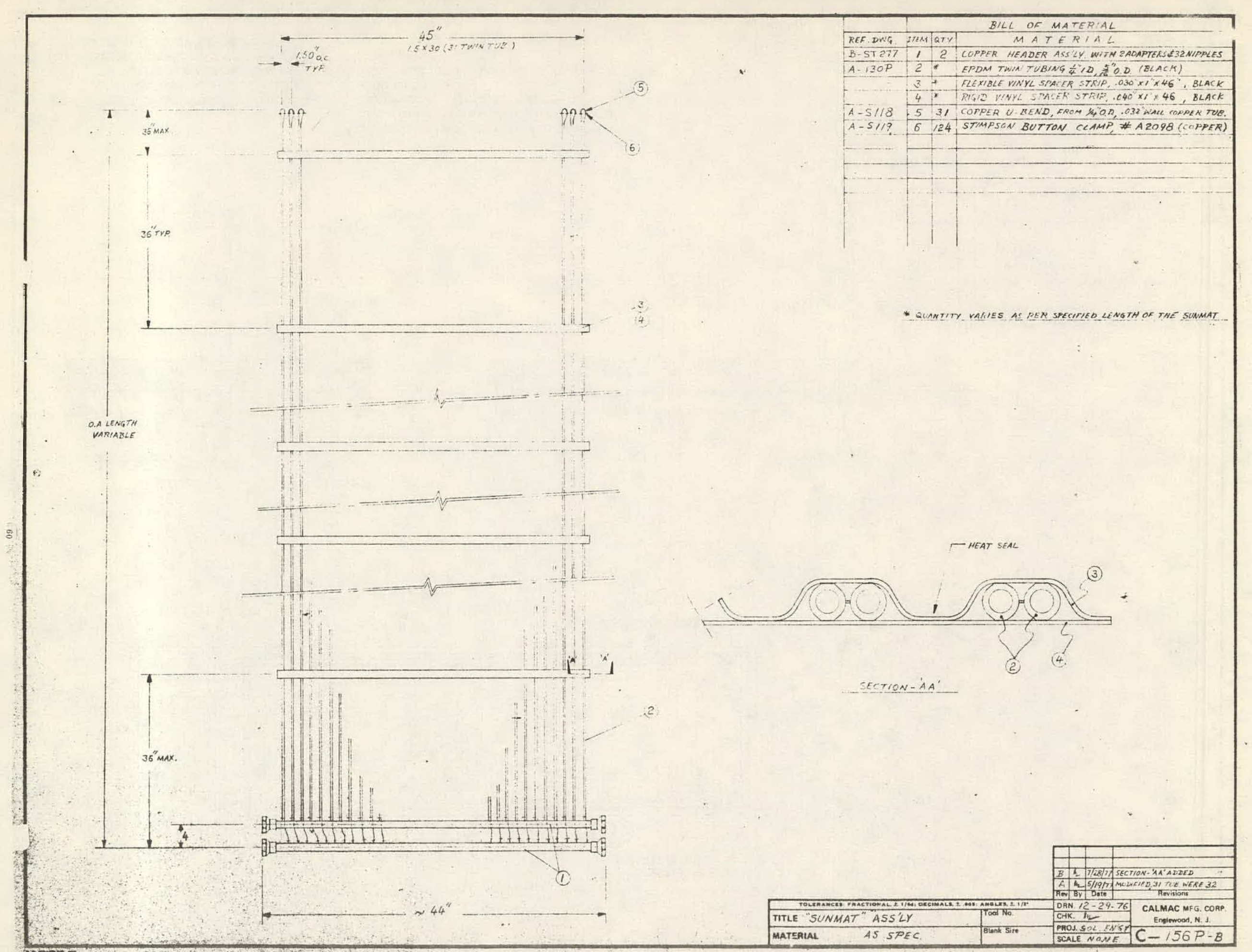


WARRANTY 
PRODUCT: SUAFAT Solar Collector Panel

CALMAC MANUFACTURING CORPORATION warrants to the OWNER of this produc that CALAAC will furnish a replacenent for any other part which ats failec in nomal use and service because of any defect in mater:d or workmanship.

DULATION OF WARRANTY: 1 year

NOTE- MHAT ANY WARRANTY REPLACED ITEM CARRIES ONLY THE UNEXPIRED PORTION OF THE ORIGINAL WARRANTY

OH.NER RESPONSIBILITIES

THE OINER MUST:

1. Have the collector panel installed with a pressure and temperature valve and in accordance with local codes and ordinances.

2. Operate the collector panel at pressures below that shown in the Operating Manual.

3. Use a heat transfer fluid that is not corrosive.

HOW TO MAKE A CLAZM

Any claim under tinis : arranty should be made to the contractor or dealer from whom the collector panel was purchased. If this cannot be done, the factory should be contacted directly.

Any item to be replaced MUST BE made available for inspection in exchange for a replacement.

ITEMS NOT COVERED BY THIS WARRANTY:

CALMAC MANUFACTURING CORPORATION WILL NOT BE RESPONSIBLE FOR:

1. Any damage resulting from water leaks or accidental dis-. charge from fittings or valves.

2. hin cl.inis resulting from loss of use of the unit, inconveriences, loss or danage to personal propesty or consequenciai danage.

3. Ay illness or injury resulting from use of toxic heat trinsso: fluid.

4. Ay lator charges for muoval or reinstallation.

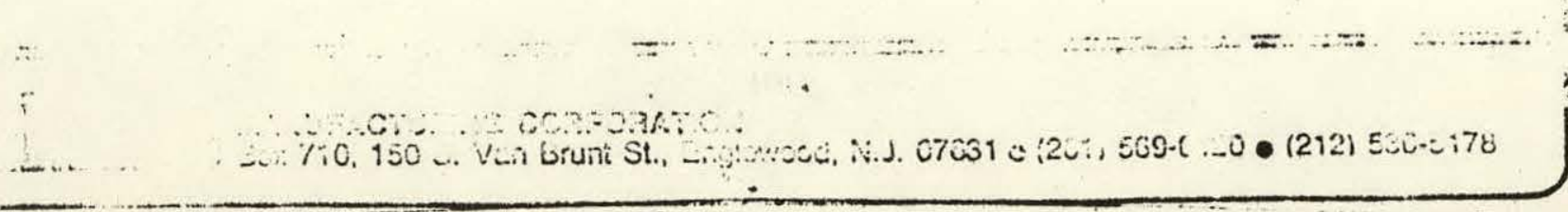


5. Failure resulting from:

a. Installation of unit without a properly installed pressure and tempersture relici valve.

b. Use of a corrosive heat transfer fluid.

c. Exposure to freezing temperatures.

6. Any shipping costs, either of the replacement unit or part to the owner, or of the defective unit to the CALMAC factory.

\title{
MSCELLENEOUS
}

No one is authorized to make any other warrar.ty on CALMAC Manufacturing Comorations behalf. Any implied warranty, including merhantability or Eitress for a particular purpose shali not extend beyond the warranty pericd from the date of original installation.

In the absence of suitable proof of instaliation the effective date of this warmanty will be based upon the month of manufacture plus three (3) :..onins.

Thi warranty gives you specific legal rights. You also have implied arzanty rights. In the event of a problem with warranty service or performance, you may be able to go to a small claims court, a State court, or a Federal district court.

\section{OWNERS RECORD---RETAIN IN YOUR FILE}

Name of Owner

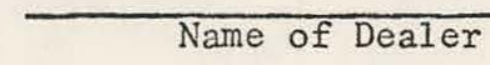

Name of Dealer
Address of Owner
Address of Dealer

Model No.

Serial No.

\author{
Date of Installation
}

